\title{
The Medio Creek Site (41BX1421): National Register Test Excavations, Bexar County, Texas
}

Richard B. Mahoney

Follow this and additional works at: https://scholarworks.sfasu.edu/ita

Part of the American Material Culture Commons, Archaeological Anthropology Commons, Environmental Studies Commons, Other American Studies Commons, Other Arts and Humanities Commons, Other History of Art, Architecture, and Archaeology Commons, and the United States History Commons

Tell us how this article helped you.

This Article is brought to you for free and open access by the Center for Regional Heritage Research at SFA ScholarWorks. It has been accepted for inclusion in Index of Texas Archaeology: Open Access Gray Literature from the Lone Star State by an authorized editor of SFA ScholarWorks. For more information, please contact cdsscholarworks@sfasu.edu. 


\section{The Medio Creek Site (41BX1421): National Register Test Excavations, Bexar County, Texas}

\section{Licensing Statement}

This is a work produced for the Texas Department of Transportation (TxDOT) by the report producer. TXDOT and the report producer jointly own all rights, title, and interest in and to all intellectual property developed under TXDOT's contract with the report producer. The report may be cited and brief passages from this publication may be reproduced without permission provided that credit is given to both TXDOT and the report producer. Permission to reprint an entire chapter, section, figures or tables must be obtained in advance from either the Supervisor of the Archeological Studies Branch, Environmental Affairs Division, Texas Department of Transportation, 125 East 11th Street, Austin, Texas, 78701 or from the report producer. 


\section{The Medio Creek Site (41BX1421): National Register Test Excavations, Bexar County, Texas}
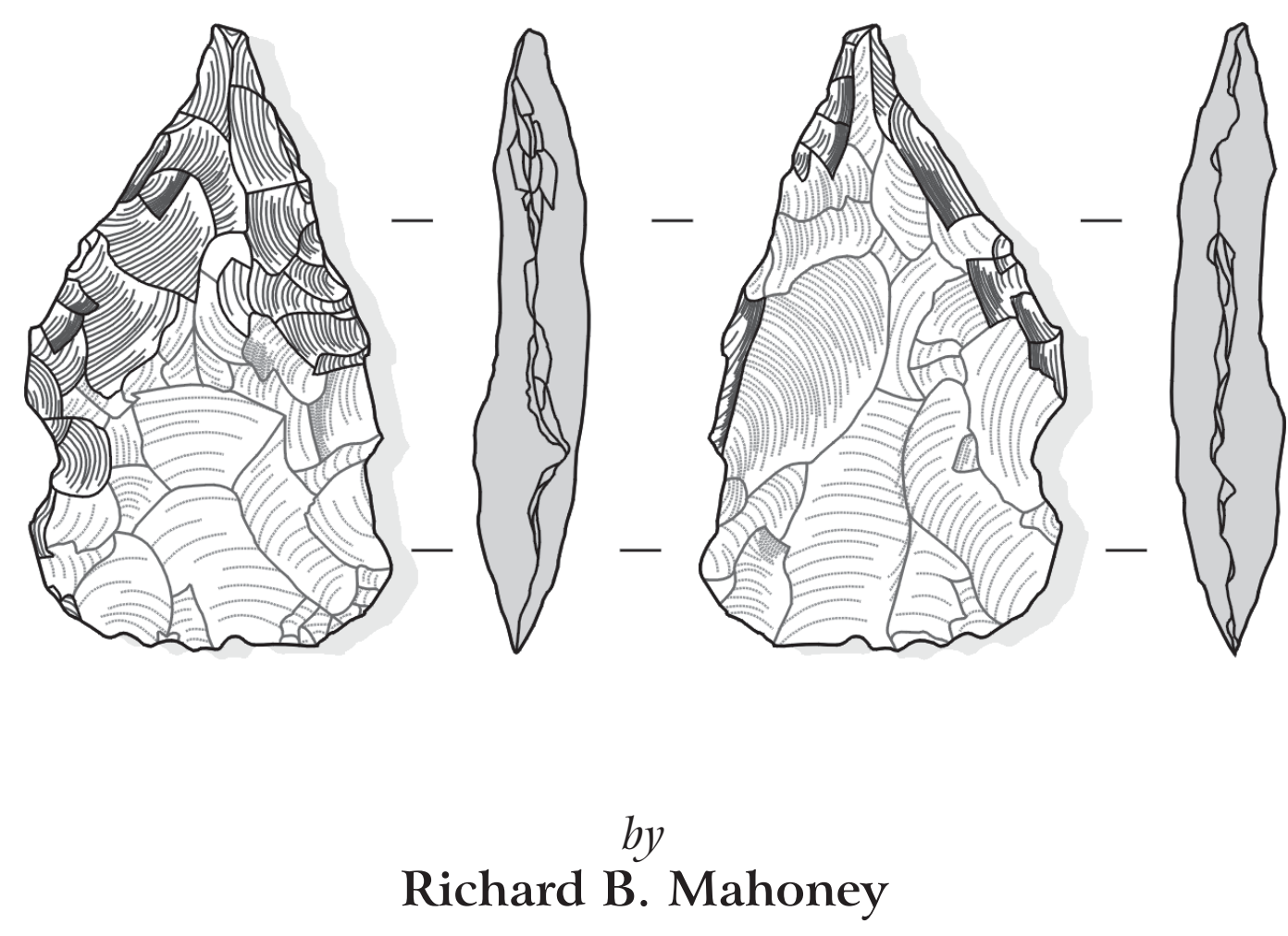

with Contributions by

Raymond P. Mauldin

and

Barbara A. Meissner

Texas Department of Transportation

Environmental Affairs Division

Archeological Studies Program, Report No. 41
Center for Archaeological Research

The University of Texas at San Antonio Archaeological Survey Report, No. 322 


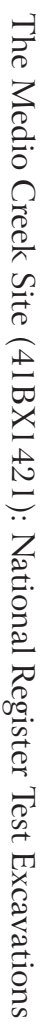

7
0
3
3
0
0
0
0

Ð్త

宽

*

?

5

3

芯

芯 


\title{
The Medio Creek Site (41BX1421): National Register Test Excavations, Bexar County, Texas
}

\author{
by \\ Richard B. Mahoney \\ with Contributions by \\ Raymond P. Mauldin \\ and \\ Barbara A. Meissner
}

Texas Antiquities Committee Permit No. 2569

Raymond P. Mauldin

Principal Investigator

Prepared for:

Texas Department of Transportation

Environmental Affairs Division

Archeological Studies Program, Report No. 41

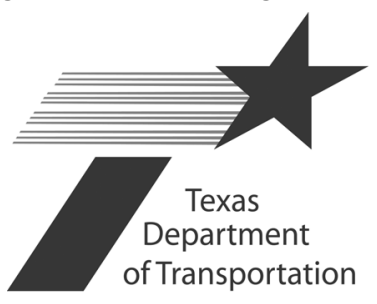

Prepared by:

Center for Archaeological Research The University of Texas at San Antonio Archaeological Survey Report, No. 322

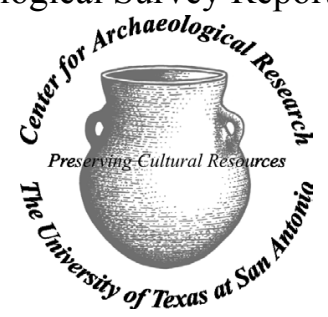




\title{
The Medio Creek Site (41BX1421): \\ National Register Test Excavations, Bexar County, Texas
}

\author{
Copyright ${ }^{{ }^{\circ}} 2002$
}

Texas Department of Transportation (TxDOT) and Center for Archaeological Research, The University of Texas at San Antonio (CAR-UTSA)

\begin{abstract}
All rights reserved
TxDOT and CAR-UTSA jointly own all rights, title, and interest in and to all data and other information developed for this project under Contract 570XXPF001. Brief passages from this publication may be reproduced without permission provided that credit is given to TxDOT and CAR-UTSA. Permission to reprint an entire chapter, section, figures or tables must be obtained in advance from the Supervisor of the Archeological Studies Program, Environmental Affairs Division, Texas Department of Transportation, 125 East 11th Street, Austin, 78701. Copies of this publication have been deposited with the Texas State Library in compliance with the State Depository requirements.
\end{abstract}

Printed by Clear Visions, Inc., San Antonio, Texas

2002

jointly published by

Texas Department of Transportation

Environmental Affairs Division

Archeological Studies Program

Nancy A. Kenmotsu, Ph.D., Supervisor

Archeological Studies Program, Report No. 41

A. McGraw, Series Editor

and

Center for Archaeological Research

The University of Texas at San Antonio

Archaeological Survey Report, No. 322

Printed on acid-free, $60 \mathrm{lb}$. paper 


\section{Abstract:}

During April 2001, the Center for Archaeological Research of The University of Texas at San Antonio conducted National Register of Historic Places eligibility testing for archeological site 41BX1421, located in southwest Bexar County, Texas, under contract with the Texas Department of Transportation. The investigations were conducted under Texas Antiquities Permit Number 2569. The Phase II testing fieldwork consisted of excavation of five test units across the site to investigate cultural deposits encountered during the previous survey phase. A single sheet midden consisting of burned limestone cobbles was encountered across the majority of the site. In concert with the archeological field investigations, the following special analyses and studies were performed to aid the determination of site integrity and eligibility: radiocarbon, lithic, aboriginal ceramic, vertebrate faunal, and magnetic sediment susceptibility. The synthesis of these analyses has provided adequate data to determine 41BX1421 ineligible for the National Register of Historic Places. It is therefore recommended that the Loop 1604 improvements proceed without further cultural resources investigations. 


\section{Table of Contents:}

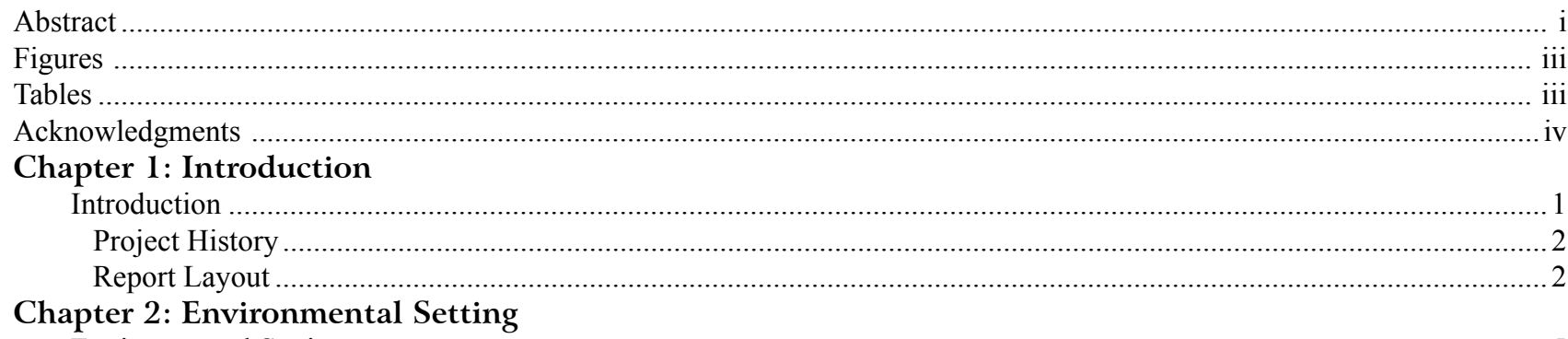

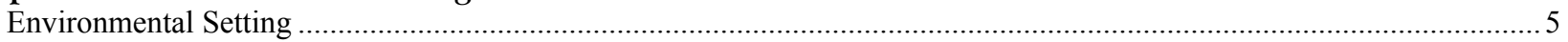

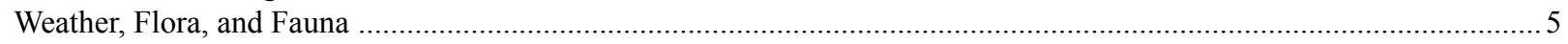

Geology and Geomorphology ........................................................................................................................ 6

Chapter 3: Archeological Background

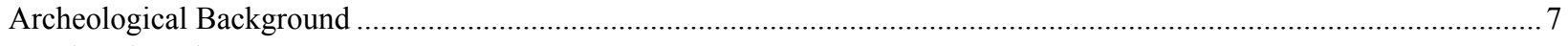

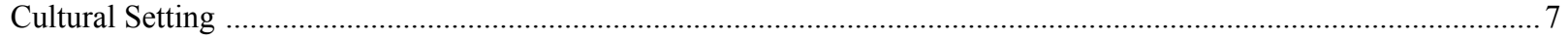

Previously Recorded Sites along Medio Creek ……………................................................................................. 9

Chapter 4: Methodology

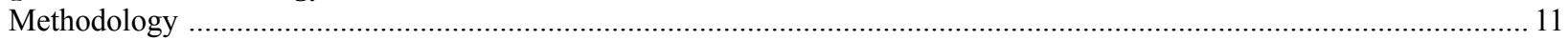

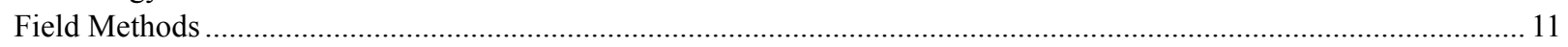

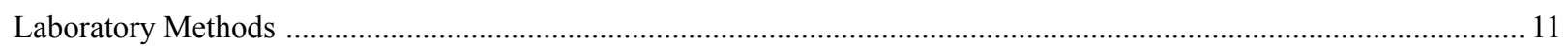

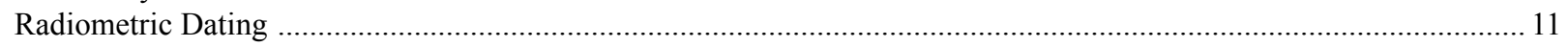

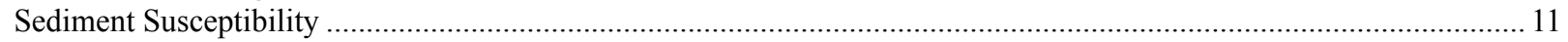

Chapter 5: Results

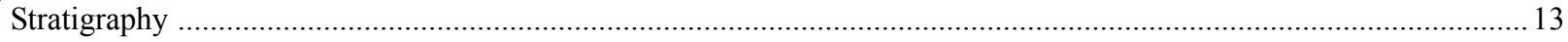

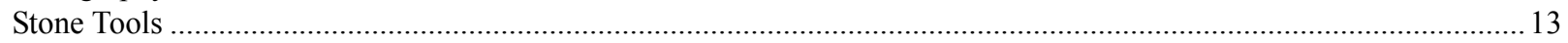

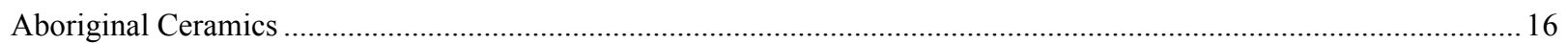

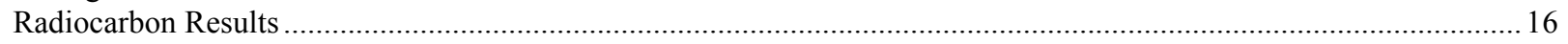

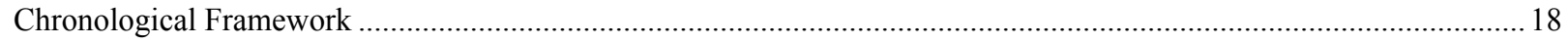

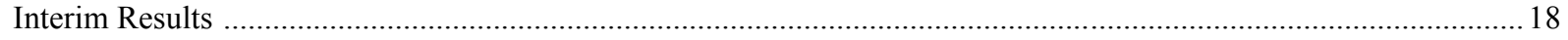

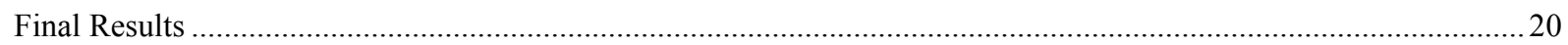

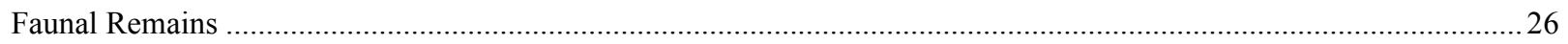

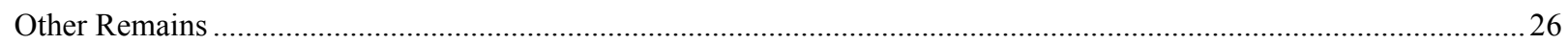

Chapter 6: Recommendations

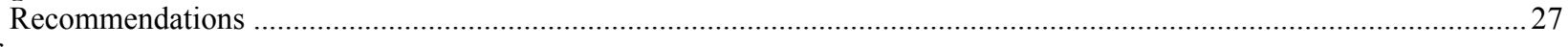

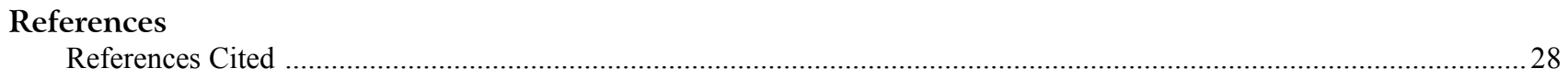

Appendix A: Magnetic Sediment Susceptibility by Raymond P. Mauldin
Susceptibility Testing

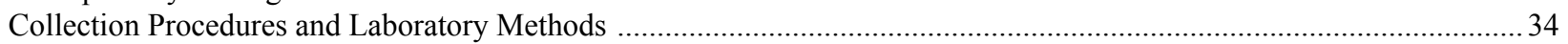

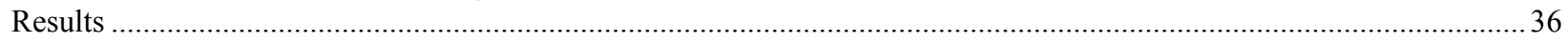

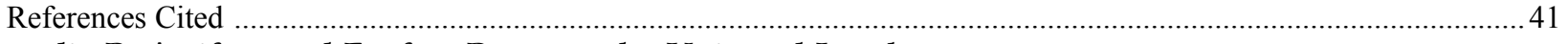

Appendix B: Artifact and Ecofact Recovery by Unit and Level

Appendix C: Radiocarbon Results

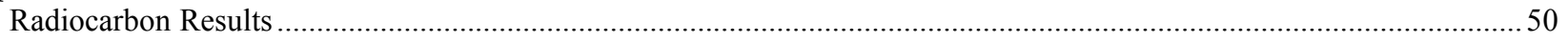

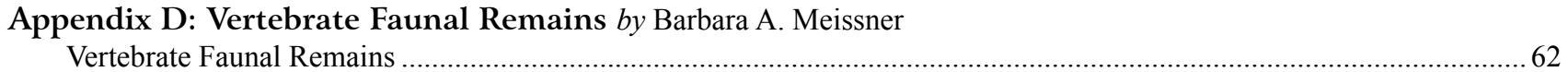




\section{Figures:}

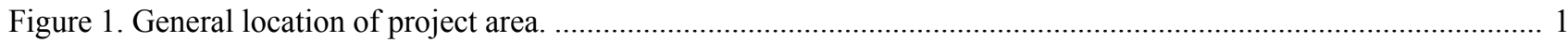

Figure 2. Total Data Station-based map of site 41BX1421. .............................................................................. 3

Figure 3. Project area in relationship to Natural Regions of Texas. ............................................................................ 5

Figure 4. Comparative cultural chronologies of Central Texas. .................................................................................... 8

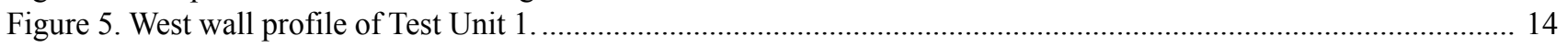

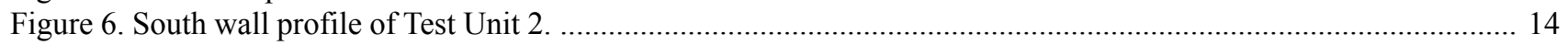

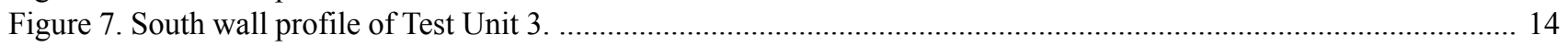

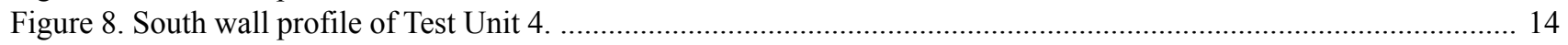

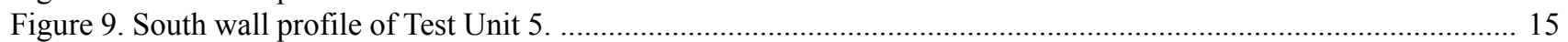

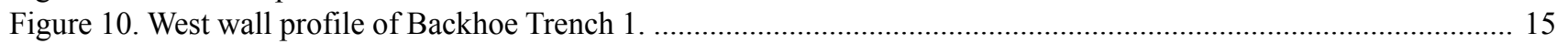

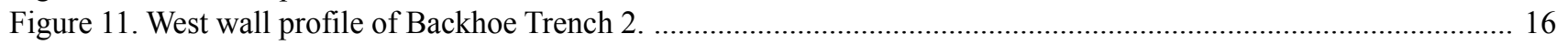

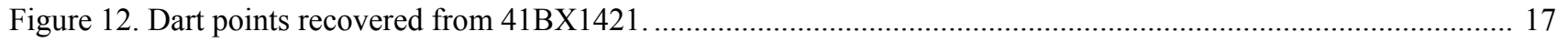

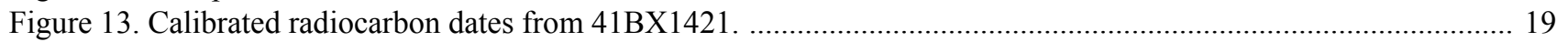

Figure 14. La Jita dart point recovered from Level 4, TU 1 at 41BX1421............................................................. 20

Figure 15. Photograph of sheet midden in Level 4, TU 5 at 41BX1421. View is to the north...................................... 21

Figure 16. Plan view of sheet midden in Level 4, TU 5 at 41BX1421.................................................................... 21

Figure 17. Photograph of sheet midden in Level 6, TU 1 at 41BX1421. View is to the south...................................... 22

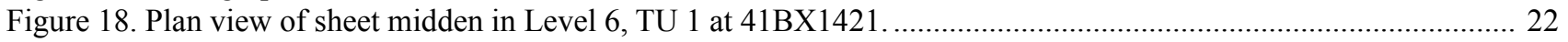

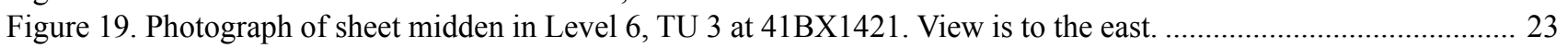

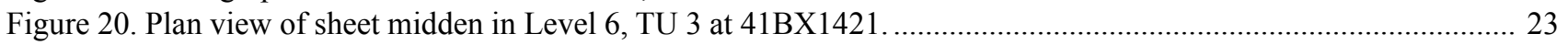

Figure A-1. Mass specific values graphs for Test Units 1 and 3 ............................................................................ 39

Figure A-2. Mass specific values graphs for Backhoe Trench 2 . .................................................................................... 40

\section{Tables:}

Table 1. Previously recorded sites along Medio Creek in Bexar County ........................................................................... 10

Table 2. Radiocarbon samples from Medio Creek testing (41BX1421) ……................................................................. 17

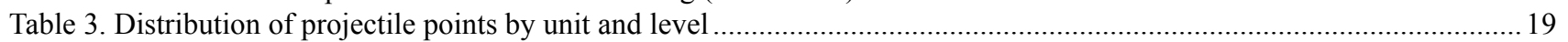

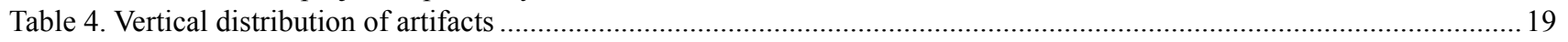

Table A-1. Magnetic sediment susceptibility data for a variety of substances .........................................................................35

Table A-2. Presence/absence of cultural material and mass specific sediment susceptibility scores .........................................36

Table A-3. Magnetic susceptibility values for Test Units 1 and 3, and Backhoe Trench 2 …................................................37

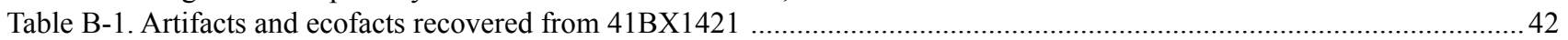

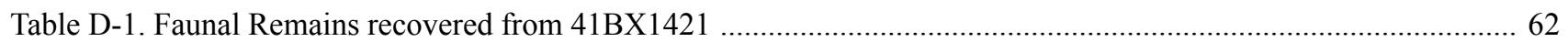

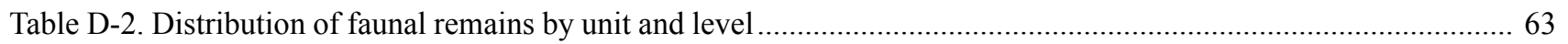




\section{Acknowledgments:}

Several individuals were instrumental in the successful completion of this project, most notably the field crew. During the field effort, the author served as project archeologist. Crew members, who endured an unseasonably warm south Texas April, included Cory Broehm, Donna Edmondson, Ruth Mathews, Kristi Ulrich, and Jason Weston. Barbara Meissner analyzed the faunal material and Richard Mahoney performed the lithic and limited ceramic analyses. Raymond Mauldin, CAR assistant director, served as principal investigator and conducted the magnetic sediment susceptibility analysis. Artifact and document curation was performed by Kristi Ulrich, Cindy Muñoz and Carol Villalobos, CAR laboratory staff under the direction of Marybeth Tomka, CAR laboratory director and collections manager. Special thanks are extended to Jason Weston of CAR for his artistry in creating the point sketch used on the cover and within the body of this report. Bruce Moses and Rick Young of CAR drafted the illustrations in the report, while Maryanne King and Johanna Hunziker, CAR editors, produced this final report. Barrlynn West, TxDOT Environmental Specialist San Antonio District, provided logistical support. Al McGraw, TxDOT staff archeologist and archeological series program editor, contributed valuable information on the local archeology of Bexar County and surrounding south Texas. Special thanks to Raymond Mauldin and Steve Tomka for providing technical advice. 
This page has been

redacted because it

contains restricted

information. 
The criteria established to determine the significance of 41BX1421 include:

1) The presence of relatively discrete and intact archeological deposits whose analysis will contribute new information to the understanding of the regional prehistoric record;

2) A demonstration that the dating of these deposits offers a valid chronological association with identifiable cultural components; and

3) A discussion of how and why the site's potential data offers a new contribution in light of the findings from similar archeological sites that have undergone previous mitigation.

\section{Project History}

Identified by Prewitt and Associates, Inc. (PAI) in 2000, 41BX1421 is located along the right descending bankline of Medio Creek on an interfluviatile terrace at its confluence with an unnamed tributary (Figure 2).

Three backhoe trenches (BHTs) and 11 shovel tests (STs) were excavated within the area of potential effect at the Loop 1604 crossing of Medio Creek. One backhoe trench and two shovel tests identified the location of 41BX1421 on the terrace (Holmes 2000).

This PAI survey effort revealed that sediments consist primarily of a ca. $100 \mathrm{~cm}$ thick deposit of fine-grained alluvium. These sediments probably represent a continuous depositional sequence of overbank deposits. Although bioturbation in the form of root disturbance was observed in these deposits, the presence of apparently intact cultural deposits suggests that only minimal displacement of cultural material has occurred. Below the fine-grained sediments there are unconsolidated gravels. Based upon cutbank profile observations, these gravels extend downward approximately $50 \mathrm{~cm}$ until contact is made with the underlying limestone bedrock.

Although no temporally diagnostic artifacts were recovered during the survey phase, PAI confirmed the presence of buried deposits with potential significance at this site. Due to the amount of recent disturbance from a sewer-line installation and the associated trackhoe trench in the northern portion of the site (see Figure 2), the survey phase indicated that approximately 50 percent of the site was intact (Holmes 2000).

\section{Report Layout}

This report is divided into six chapters with four appendices. Following the introduction, the Environmental Setting chapter briefly discusses the general physical environment of the project area. The third chapter, Archeological Background, provides an overview of the project history and cultural setting of the region. Methodology, chapter four, describes in detail the field methods, laboratory methods, and special analyses employed during the investigations. The fifth chapter, Results, discusses the results from the field and laboratory investigations. The sixth and final section, Recommendations, discusses the National Register of Historic Places (NRHP) eligibility of 41BX1421. The appendices follow, Appendix A presents the results of soil susceptibility analyses conducted for two of the test units and one of the backhoe trenches. Appendix B contains a unit by level summary of recovered material from the CAR excavation. Appendix C contains radiocarbon results from Beta Analytic, Inc., and Appendix D presents the results of the faunal analysis. 


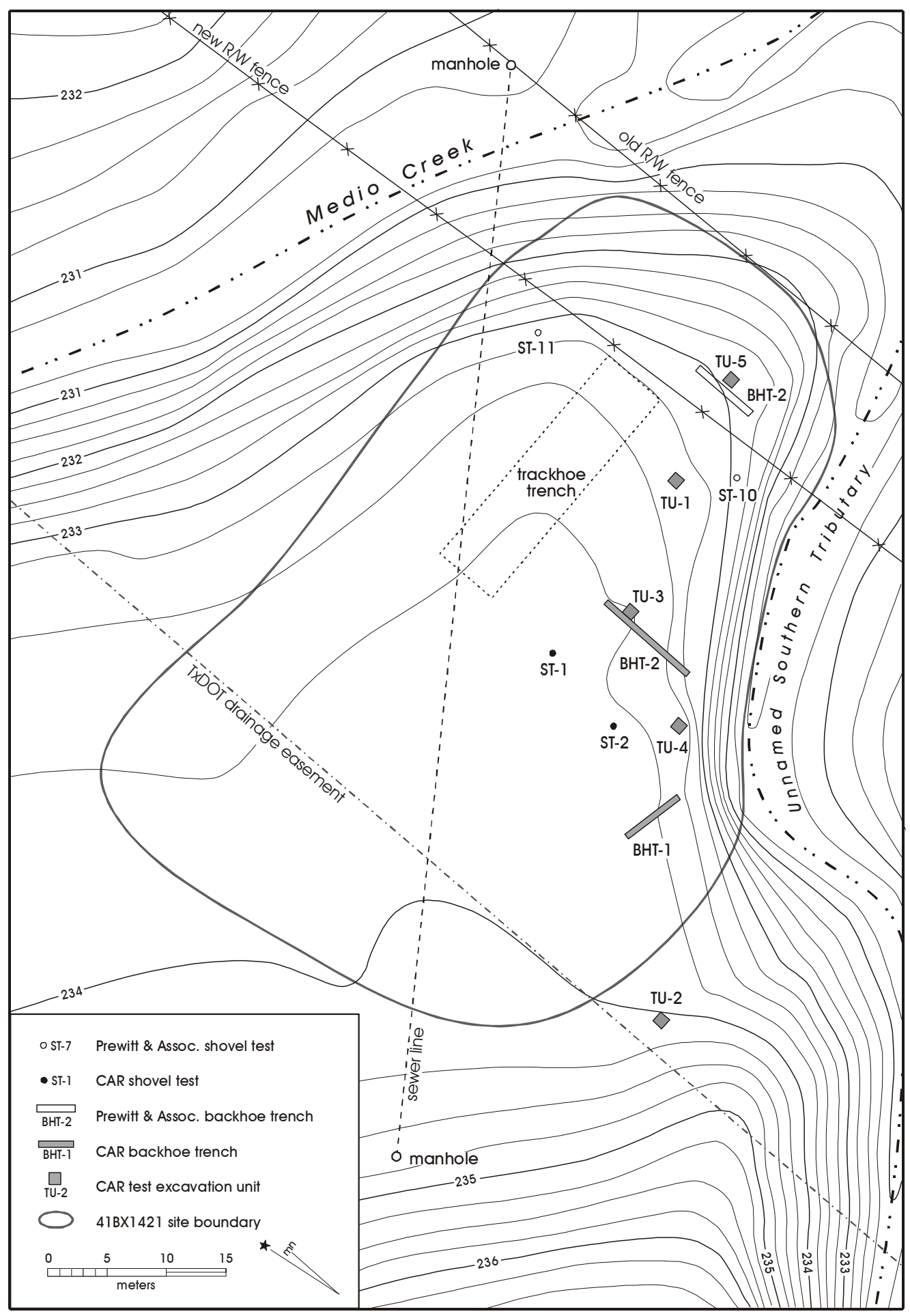

Figure 2. Total Data Station-based map of site 41BX1421. 



\section{Chapter 2: $\quad$ Environmental Setting}

As the environment of Bexar County is quite diverse, a summary of the environment specific to the immediate project area is provided to furnish a background for understanding prehistoric human adaptations to the South Texas Brush Country, Blackland Prairie, and Edwards Plateau vegetation regions at this juncture (Figure 3).

Medio Creek heads in the Edwards Plateau of eastern Medina County, follows a sinuous course through limestone bedrocks and upland gravels across the Balcones Escarpment, and confluences with Medina River in the Blackland Prairies of south-central Bexar County. 41BX1421 is situated near the base of the escarpment along an interfluviatile terrace of Medio Creek and an unnamed tributary.

\section{Weather, Flora, and Fauna}

Bexar County has a subtropical climate, with warm winters and hot summers. The average winter temperature is $58^{\circ} \mathrm{F}\left(14^{\circ} \mathrm{C}\right)$ and the average summer temperature is $80^{\circ} \mathrm{F}\left(27^{\circ} \mathrm{C}\right)$. The growing season averages around 245 days a year in the northern half of the county and 275 days a year in the southern half of the county. The prevailing winds are light $(8$ knots $)$ and predominately flow from the southeast. The average annual precipitation is 31 inches $(79 \mathrm{~cm})$, with rainfall evenly distributed throughout the year (Taylor et al. 1991:118). Atlantic hurricanes occasionally affect the county, causing high winds and sporadic, heavy rainfall.

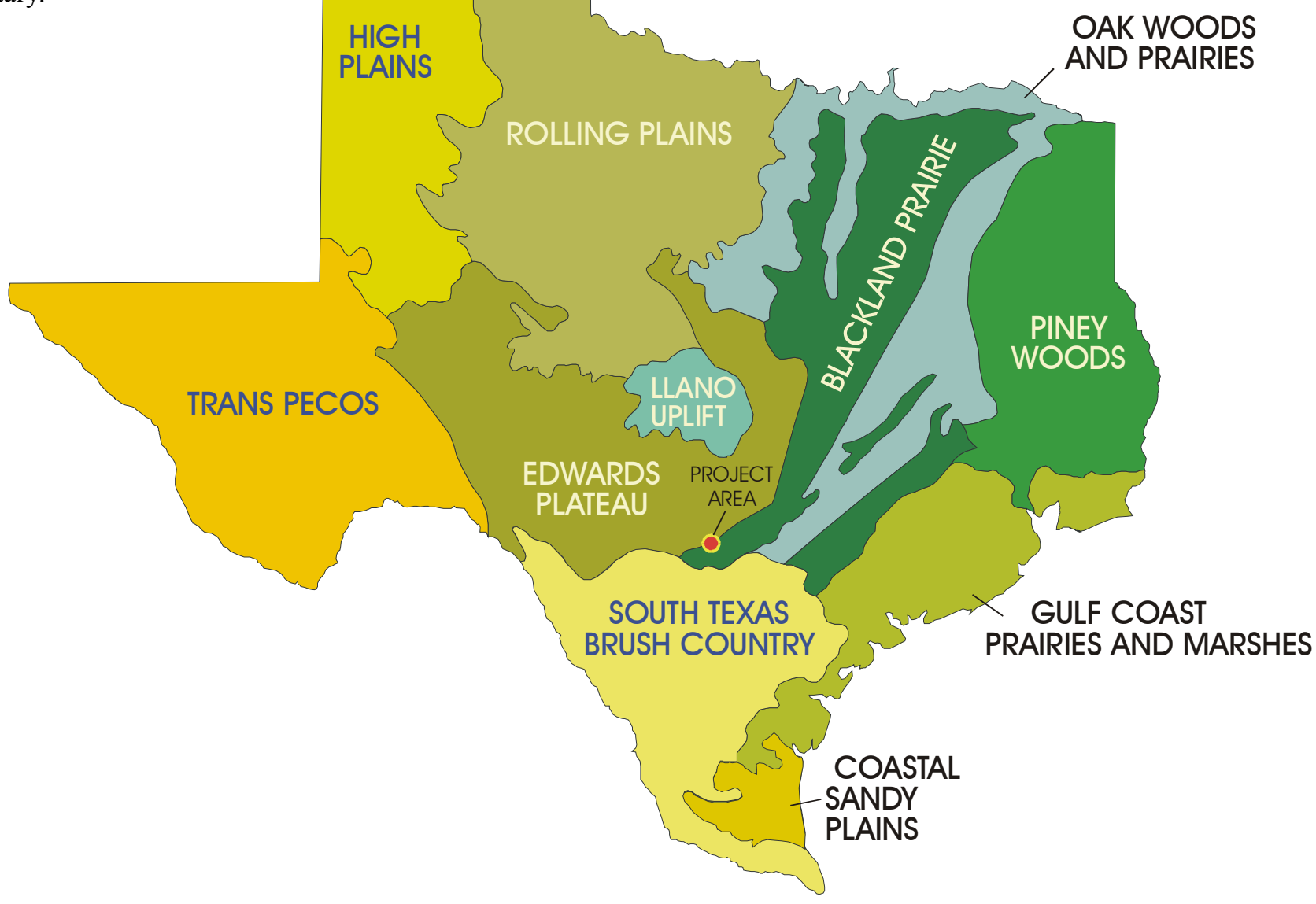

Figure 3. Project area in relationship to Natural Regions of Texas. 
The project area lies along the northern boundary of the Tamaulipan biotic region of South Texas, a region characterized by thorny brush, including mesquite, acacia, white brush, and prickly pear (Blair 1950:103). The northern boundary of this region is formed by the Balcones escarpment and fault line. The site is in close proximity to and on the downthrown side of a fault located to the north. This upstream fault line locus may have affected dependability of Medio Creek in prehistoric times.

Blair (1950:104) identifies the fauna of the region as diverse with numerous species of mammals, reptiles, and amphibians. Certainly, the riparian zones along the two streams would have afforded a resource-rich environment for such mammals as white-tailed deer, rabbit, squirrel, raccoon, opossum, skunk, and various rodents. Similarly, reptiles, amphibians, fish, and bivalves would have likely favored such a riparian area.

\section{Geology and Geomorphology}

The geology of Bexar County consists primarily of Mesozoic formations beginning with the Cretaceous Trinity Group in the northwest and continuing with the Eocene Claiborne Group in the extreme southeast. Quaternary undivided is mapped in the central portion of the county, underlying the southern part of the city of San Antonio. Located in the Upper Cretaceous Pecan Gap Chalk of thick chalk (Barnes 1976), 41BX1421 is situated within Holocene alluvial deposits of Medio Creek at its confluence with an unnamed tributary.

The project area is within the West Gulf Coastal Plain section of the Coastal Plains physiographic region (Fenneman 1931). The Austin-Tarrant Association of moderately deep and very shallow, clayey soils over chalk and marl comprises the area of current investigations, which generally conforms to the published soil descriptions of the various components (Taylor et al. 1991). More specifically, the soil is further delineated as Trinity-Frio soils (Taylor et al. 1991:Sheet 51), with Tarrant soils occupying the associated uplands of the stream and Frio soils comprising the floodplains and terraces of the stream. 


\section{Chapter 3: $\quad$ Archeological Background}

A brief overview of the aboriginal cultural setting of South Texas relative to the project area and a synopsis of previous archeological investigations conducted along Medio Creek is presented in this chapter. These summaries are based, in part, on more comprehensive reviews of cultural chronologies and archeological investigations found in Black (1989), Hester (1995), Tomka et al. (1997), and Vierra (1998).

\section{Cultural Setting}

The cultural setting of Bexar County is discussed relative to the chronology exhibited by temporally diagnostic stone tools and the radiocarbon dates wrought from in situ charcoal samples excavated at 41BX1421. This discussion begins with the Middle Archaic and continues through the Late Prehistoric for South Texas as defined by Hester (1978). The currently accepted cultural chronology for South Texas is depicted in Figure 4.

Predominantly triangular projectile points, an increase in the diversity of stone tools, and promulgation of burned rock features distinguish the Middle Archaic from earlier periods. The paucity of paleoenvironmental indicators such as charred plant remains, fossil pollen, and other macrobotanicals has left primarily the lithic classes to interpret this interval of the Archaic era for extreme South Texas.

One notable exception, however, is the encounter of over 200 burials with associated grave goods at the Loma Sandia site (41LK28) in Lone Oak County (Taylor and Highley 1995). Located atop an upland landform adjacent Hackberry Creek, a tributary of the Frio River, the site provides a glimpse into the mortuary practices of the peoples of the Middle Archaic in South Texas few other sites offer. Prior to these extensive excavations, very limited data regarding true cemeteries existed for the region as a whole (Steele and Olive 1989), and certainly so for extreme South Texas.

Hester (1995:438) cites the presence of Tortugas, Abasolo, and Carrizo dart points as "region-specific" and temporally diagnostic indicators of the South Texas Middle Archaic. Scrapers, gouges, choppers, and wedges round out the formal stone tool forms recovered from occupation sites. The variety of this collection suggests subsistence and adaptation diverse from the mobile bands of the Early Archaic of South Texas (Hester 1995:436). Black (1989:51) proposes that this shift in strategy may have been central in the inferred population increase during this time. Excavations at Choke Canyon (Hall et al. 1986:402) have recovered macrobotanical remains of mesquite and acacia in association with burned rock features and grinding tools, suggesting a greater reliance on vegetation. Further, Holloway (1986:448) suggests a stable environment, consistent with modern taxa, to at least $6,000 \mathrm{BP}$.

The occurrence of burned rock middens and features at Loma Sandia, similar to those defined in Central Texas would further indicate a population growth and a less nomadic lifestyle. With the encounter of numerous hearths during the Choke Canyon investigations, Hall et al. (1986) suggest an increased dependence on vegetation resources, including the aforementioned mesquite and acacia. Following Holloway's (1986) conclusions, a diverse array of succulents, semi-succulents and legumes may have similarly been available during the Middle Archaic of Bexar County.

The transition from the Middle Archaic to the Late Archaic in South Texas witnesses an increase in site densities, a proliferation of burned rock middens, and a shift to generally smaller projectile points. Paleoenvironmental indicators in the form of charred plant remains and faunal material become more visible in the archeological record. Small vertebrates, such as rodent, rabbit/hare, reptile, and fish comprise the Late Archaic faunal assemblage of recovered materials from the Choke Canyon investigations (Hall et al. 1982:471). Focus on these smaller faunal resources suggests more xeric conditions during this time, with larger mammals either migrating from the region and/or, albeit in smaller numbers, relegated to the less abundant riparian zones, such as Medio Creek, within South Texas.

Radiocarbon assays from Late Archaic sites in the Choke Canyon excavations verify the increase in site densities during this time. Of note are the 44 sites containing evidence of Late Archaic occupation recorded during 


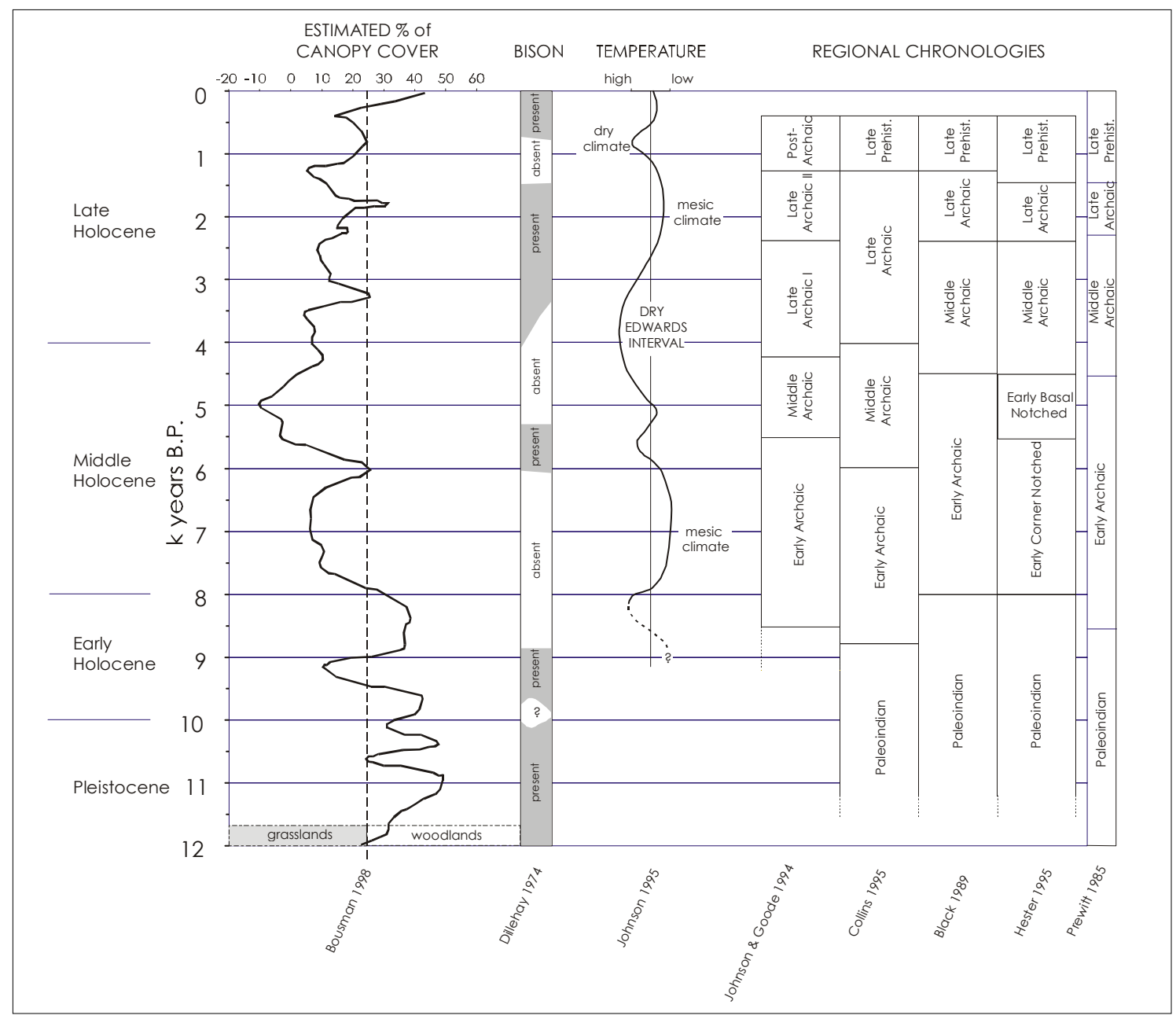

Figure 4. Comparative cultural chronologies of Central Texas.

the Choke Canyon investigations (Hall et al. 1986:400). It is conceivable, then, that the increase in burned rock features during this time is attributable to an increase in reliance on vegetation.

Lithic technology appears to be the greatest division between the Middle and Late Archaic periods. Small sidenotched and corner-notched dart points such as Ensor and Fairland types are index markers of the Late Archaic at the Choke Canyon sites (Hall et al. 1982:465). These dart points, along with the Frio type, form the EnsorFrio-Fairland component of Central Texas. Collins (1995:384, Table 2) considers these three point types to be contemporaneous and, together as a point style interval, constitutes one of the later intervals of the Late Archaic period for Central Texas. At the Panther Springs Creek site (41BX228), 41BX300, 41BX1, and the Cibolo
Creek Crossing site (41BX377) these point types have been excavated in similar contexts with good integrity (Black and McGraw 1985; Katz 1987; Lukowski 1988; Kibler and Scott 2000, respectively). The Ensor-FrioFairland component straddles the latter part of the Uvalde Phase and is a portion of the representative artifact assemblage of the succeeding Twin Sisters Phase in Central Texas (Prewitt 1981:81).

The Late Prehistoric in South Texas has been likened to the same chronology in Central Texas (Black 1989:52), sharing similar delineations of the Austin and Toyah intervals. Transition from the Late Archaic to the Late Prehistoric is arguably accepted to occur with the advancement in technology from hunting techniques utilizing the atlatl and dart to utilization of the bow and arrow. However, as Hester notes (1995:443), smaller dart 
points such as Matamoros and Catán have been recovered in Late Prehistoric contexts. Hester (1971) further suggests the existence of a true Transitional Archaic for South Texas, with Late Archaic dart point types such as Frio and Ensor carrying over well into the Austin interval.

For Central Texas, Prewitt identifies the succeeding Late Prehistoric interval as the Austin interval, occurring from the termination of the Late Archaic II until approximately 650 вр (Prewitt 1981:Figure 3). Aside from the aforementioned changes in technology, Prewitt (1981:74) ascribes only a slight increase in the dependence upon hunting as a means of subsistence and a marked increase in the occurrence of "true cemeteries" as an indicator of period change. The Transitional Archaic for this region of Texas would be generally coeval with the Austin interval, and, as suggested at 41BX1421, may have actually subsumed the entire interval.

The relatively short-lived Toyah interval, as defined by Prewitt (1981), is characterized by the "dramatic" shift in subsistence from hunter-gatherer to that of an economy based primarily on hunting. Based upon data from Dillehay (1974), bison once again reappear in the faunal assemblage of archeological sites within Central Texas. An intermediate shift to a generally wet, mesic environment is attributed to this influx of ungulate dependence (Johnson 1995). The material culture of this time period appears to reflect subsistence based on the procurement of bison in the form of various stone tools utilized for bison procurement and processing, such as Perdiz and Clifton arrow points, along with various scrapers and other stone tools.

\section{Previously Recorded Sites along Medio Creek} A total of 66 sites have been recorded along Medio Creek in Bexar County over the previous three decades of archeological research within the region (Table 1). The first systematic survey of Medio Creek was conducted in 1977 by CAR, recording the first 15 sites along the stream (McGraw 1977). Seven of these sites were reassessed during the survey and assessment of the proposed Applewhite Reservoir project. None exhibited qualities consistent with criteria necessary for inclusion in the NRHP (McGraw and Hindes 1987).

Of these fifteen sites, 41BX466 was recorded in closest proximity to the current project area. According to Texas Archeological Site Forms listed on the Texas Archeological
Sites Atlas (THC 2002), 41BX466 is located approximately $100 \mathrm{~m}$ due west of 41BX1421. This locus sits atop the upland interfluve formed by Medio Creek and the unnamed tributary. No temporally diagnostic artifacts were encountered during the survey, however bifacial scrapers and a uniface were recovered (McGraw 1977:12). It is possible that the single Nolan dart point recovered during the present survey (see Chapter 5), a result of colluvial deposition, was originally associated with this upland site.

Some of the more intensive archeological investigations in the region have been conducted along the Balcones Escarpment in Bexar County. Projects such as Wurzbach Parkway (Potter and Black 1995) have afforded testing and assessment of several sites in the northern portion of the county. Similarly, excavations at the Panther Springs Creek site (41BX228) and 41BX300 have provided data recoverylevel studies of isolated sites along primary tributaries (Black and McGraw 1985; Katz 1987, respectively). Most recently, TxDOT and CAR conducted test efforts at the Culebra Creek Site (41BX126), documenting Middle and Late Archaic occupations associated with three terraces of the stream (Nickels et al. 2001).

Of note is the site's proximity to Padrone Hill (also Loma Padron) in the western portion of the county. The hill, historically utilized as a natural landmark, certainly would have served a similar function prehistorically as it is the highest point in Bexar County (McGraw et al. 1998), reaching over $930 \mathrm{ft}$ (284 m) AMSL. According to McGraw et al. (1998:144), Padrone Hill formed the northeastern corner of Rancho San Lucas, the eighteenth century mission ranch of San José y San Miguel de Aguayo. Site 41BX1421 is located approximately 1.7 $\mathrm{km}$ (1 mile) northeast of the hill.

A later survey by CAR of the Lackland Air Force Base (Nickels et al. 1997) recorded an additional 45 sites along Medio Creek and its associated floodplain. Subsequent to the recommendations of the survey by CAR, eight of these sites were tested for NRHP eligibility. These testing efforts identified two sites, 41BX1102 and 41BX1103, that were recommended for inclusion in the NRHP. Site 41BX1102 consists of a definable Late Archaic component with numerous Pedernales dart points recovered in good context. Site 41BX1103 contains a Frio-Ensor-Fairland component of the Late Archaic II period; however, the majority of the diagnostics were recovered from surface collections (Houk and Nickels 1997). 
Table 1. Previously recorded sites along Medio Creek in Bexar County

\begin{tabular}{|c|c|c|c|c|c|c|c|c|c|}
\hline $\begin{array}{c}\text { Trinomial } \\
41 \mathrm{BX} \ldots\end{array}$ & $\mathbf{P} / \mathbf{H}^{*}$ & $\begin{array}{c}\text { Cultural } \\
\text { Component** }\end{array}$ & Site Type*** & Soil & Landform & $\begin{array}{l}\text { Distance to } \\
\text { Water (m) }\end{array}$ & $\begin{array}{l}\text { Site Size } \\
(\mathrm{m})\end{array}$ & Project & $\underset{* * * *}{\text { BR }}$ \\
\hline 343 & $\mathrm{P}$ & Unknown & LRS & Silty Clay & Terrace & 50 & $200 \times 150$ & CAR Applewhite & - \\
\hline 368 & $\mathrm{P}$ & Unknown & Campsite & Silty Clay & Upland & 100 & $300 \times 250$ & CAR & $\mathrm{X}$ \\
\hline 459 & $\mathrm{P}$ & EA, LA, LP & Campsite & Clay Loam & Upland & $0 \dagger$ & $300 \times 100$ & CAR Medio Creek Survey & $\mathrm{X}$ \\
\hline 460 & $\mathrm{P}$ & Unknown & Campsite & Clay Loam & Upland & $0 \dagger$ & $200 \times 200$ & CAR Medio Creek Survey & $\mathrm{X}$ \\
\hline 461 & $\mathrm{P}$ & LP & Campsite & Clay Loam & Upland & $0 \dagger$ & $275 \times 200$ & CAR Medio Creek Survey & - \\
\hline 462 & $\mathrm{P}$ & Unknown & LRS & $?$ & Upland & $0 \dagger$ & $120 \times 100$ & CAR Medio Creek Survey & - \\
\hline 463 & $\mathrm{P}$ & LP & Campsite & $?$ & Upland & $?$ & $75 \times 50$ & CAR Medio Creek Survey & $\mathrm{x}$ \\
\hline 464 & $\mathrm{P}$ & Unknown & LRS & $?$ & Upland & $?$ & $400 \times 450$ & CAR Medio Creek Survey & - \\
\hline 465 & $\mathrm{P}$ & Unknown & LRS & $?$ & Terrace & 25 & $350 \times 100$ & CAR Medio Creek Survey & $X$ \\
\hline 466 & $\mathrm{P}$ & Unknown & LRS & $?$ & Upland & $?$ & $75 \times 30$ & CAR Medio Creek Survey & - \\
\hline 467 & $\mathrm{P}$ & Unknown & Campsite & $?$ & Terrace & $0+$ & $50 \times 50$ & CAR Medio Creek Survey & $\mathrm{X}$ \\
\hline 468 & $\mathrm{P}$ & MA, LA, LP & Campsite & $?$ & Terrace & 15 & $100 \times 75$ & CAR Medio Creek Survey & $\mathrm{X}$ \\
\hline 469 & $\mathrm{P}$ & Unknown & LRS & ? & Terrace & $0 \dagger$ & $150 \times 60$ & CAR Medio Creek Survey & - \\
\hline 470 & $\mathrm{P}$ & Unknown & Campsite & $?$ & Terrace & $0 \dagger$ & $230 \times 75$ & CAR Medio Creek Survey & - \\
\hline 471 & $\mathrm{P}$ & Unknown & Campsite & $?$ & Upland & $?$ & $?$ & CAR Medio Creek Survey & $\mathrm{X}$ \\
\hline 472 & $\mathrm{P}$ & Unknown & Unknown & $?$ & Upland & $?$ & $?$ & CAR Medio Creek Survey & - \\
\hline 569 & $\mathrm{P}$ & Unknown & Quarry & Silty Clay & Upland & 500 & $200 \times 300$ & CAR Applewhite & - \\
\hline 762 & $?$ & $?$ & $?$ & $?$ & $?$ & 10 & $?$ & EHA West Creek Survey & $?$ \\
\hline 763 & $\mathrm{P}$ & Unknown & LRS & $?$ & Terrace & 10 & $20 \times 20$ & EHA West Creek Survey & $?$ \\
\hline 764 & $?$ & $?$ & $?$ & $?$ & $?$ & 10 & $?$ & EHA West Creek Survey & $?$ \\
\hline 1002 & $\mathrm{P} / \mathrm{H}$ & EA & Campsite & Silty Clay & Terrace & $0+$ & $400 \times 100$ & CAR Lackland AFB Survey & - \\
\hline 1060 & $\mathrm{P}$ & Unknown & Campsite & Silty Clay & Terrace & 120 & $27 \times 10$ & CAR Lackland AFB Survey & $\mathrm{X}$ \\
\hline 1069 & $\mathrm{P}$ & MA & Campsite & Silty Clay & Terrace & 30 & $125 \times 50$ & CAR Lackland AFB Survey & $\mathrm{X}$ \\
\hline 1070 & $\mathrm{P}$ & Unknown & LRS & Silty Clay & Upland & 200 & $40 \times 10$ & CAR Lackland AFB Survey & - \\
\hline 1071 & $\mathrm{P}$ & LA & Campsite & Silty Clay & Upland & 800 & $140 \times 60$ & CAR Lackland AFB Survey & - \\
\hline 1074 & $\mathrm{P} / \mathrm{H}$ & LP & Campsite & Silty Clay & Upland & 700 & $30 \times 30$ & CAR Lackland AFB Survey & - \\
\hline 1075 & $\mathrm{P}$ & Unknown & LRS & Silty Clay & Upland & 750 & $30 \times 20$ & CAR Lackland AFB Survey & - \\
\hline 1076 & $\mathrm{P}$ & LP & Campsite & Clay Loam & Upland & 10 & $70 \times 40$ & CAR Lackland AFB Survey & $\mathrm{X}$ \\
\hline 1077 & $\mathrm{P}$ & Unknown & LRS & Silty Clay & Terrace & 300 & $35 \times 40$ & CAR Lackland AFB Survey & - \\
\hline 1078 & $\mathrm{P}$ & Unknown & LRS & Silty Clay & Upland & 500 & $45 \times 25$ & CAR Lackland AFB Survey & - \\
\hline 1079 & $\mathrm{P}$ & Unknown & LRS & Silty Clay & Terrace & 300 & $30 \times 15$ & CAR Lackland AFB Survey & - \\
\hline 1080 & $\mathrm{P}$ & Unknown & LRS & Silty Clay & Upland & 700 & $20 \times 15$ & CAR Lackland AFB Survey & - \\
\hline 1081 & $\mathrm{P}$ & Unknown & LRS & Silty Clay & Upland & 570 & $75 \times 35$ & CAR Lackland AFB Survey & - \\
\hline 1082 & $\mathrm{P}$ & Unknown & Campsite & Silty Clay & Upland & 670 & $60 \times 35$ & CAR Lackland AFB Survey & $\mathrm{X}$ \\
\hline 1083 & $\mathrm{P}$ & Unknown & LRS & Silty Clay & Upland & 1000 & $30 \times 30$ & CAR Lackland AFB Survey & - \\
\hline 1084 & $\mathrm{P}$ & Unknown & LRS & Silty Clay & Upland & 1000 & $50 \times 40$ & CAR Lackland AFB Survey & - \\
\hline 1085 & $\mathrm{P}$ & Unknown & LRS & Silty Clay & Upland & 1000 & $90 \times 80$ & CAR Lackland AFB Survey & - \\
\hline 1086 & $\mathrm{P}$ & Unknown & Campsite & Silty Clay & Terrace & 400 & $25 \times 20$ & CAR Lackland AFB Survey & $\mathrm{X}$ \\
\hline 1087 & $\mathrm{P}$ & LA & Campsite & Clay Loam & Terrace & 200 & $20 \times 15$ & CAR Lackland AFB Survey & $\mathrm{X}$ \\
\hline 1088 & $\mathrm{P}$ & EA,MA,LA & Campsite & Silty Clay & Upland & 200 & $500 \times 330$ & CAR Lackland AFB Survey & $\mathrm{X}$ \\
\hline 1089 & $\mathrm{P}$ & Unknown & LRS & Silty Clay & Upland & 800 & $35 \times 30$ & CAR Lackland AFB Survey & - \\
\hline 1090 & $\mathrm{P}$ & Unknown & Campsite & Silty Clay & Upland & 900 & $30 \times 25$ & CAR Lackland AFB Survey & $\mathrm{X}$ \\
\hline 1091 & $\mathrm{P}$ & Unknown & LRS & Silty Clay & Upland & 550 & $25 \times 15$ & CAR Lackland AFB Survey & - \\
\hline 1092 & $\mathrm{P}$ & Unknown & Campsite & Silty Clay & Terrace & 90 & $35 \times 15$ & CAR Lackland AFB Survey & $\mathrm{X}$ \\
\hline 1093 & $\mathrm{P}$ & Unknown & Campsite & Silty Clay & Terrace & 45 & $50 \times 25$ & CAR Lackland AFB Survey & $\mathrm{X}$ \\
\hline 1094 & $\mathrm{P}$ & Unknown & LRS & Silty Clay & Terrace & 230 & $35 \times 25$ & CAR Lackland AFB Survey & - \\
\hline 1095 & $\mathrm{P}$ & Unknown & LRS & Silty Clay & Upland & 480 & $30 \times 20$ & CAR Lackland AFB Survey & - \\
\hline 1096 & $\mathrm{P}$ & Unknown & LRS & Silty Clay & Upland & 500 & $20 \times 15$ & CAR Lackland AFB Survey & - \\
\hline 1097 & $\mathrm{P}$ & Unknown & LRS & Silty Clay & Upland & 730 & $35 \times 20$ & CAR Lackland AFB Survey & - \\
\hline 1102 & $\mathrm{P}$ & LA & Campsite & Silty Clay & Terrace & 150 & $50 \times 35$ & CAR Lackland AFB Survey & $\mathrm{X}$ \\
\hline 1103 & $\mathrm{P}$ & LA & Campsite & Silty Clay & Terrace & 70 & $30 \times 25$ & CAR Lackland AFB Survey & $\mathrm{X}$ \\
\hline 1105 & $\mathrm{P}$ & Unknown & LRS & Silty Clay & Upland & 320 & $50 \times 45$ & CAR Lackland AFB Survey & - \\
\hline 1106 & $\mathrm{P}$ & Unknown & LRS & Silty Clay & Upland & 300 & $25 \times 25$ & CAR Lackland AFB Survey & - \\
\hline 1114 & $\mathrm{P}$ & EA & Campsite & Silty Clay & Terrace & 25 & $225 \times 40$ & CAR Lackland AFB Survey & $\mathrm{X}$ \\
\hline 1115 & $\mathrm{P}$ & Unknown & Campsite & Silty Clay & Terrace & 135 & $60 \times 30$ & CAR Lackland AFB Survey & $\mathrm{X}$ \\
\hline 1119 & $\mathrm{P}$ & Unknown & LRS & Silty Clay & Terrace & 65 & $30 \times 20$ & CAR Lackland AFB Survey & - \\
\hline 1120 & $\mathrm{P}$ & Unknown & Campsite & Silty Clay & Terrace & 200 & $10 \times 7$ & CAR Lackland AFB Survey & $\mathrm{X}$ \\
\hline 1121 & $\mathrm{P} / \mathrm{H}$ & MA & Campsite & Clay Loam & Terrace & 35 & $50 \times 35$ & CAR Lackland AFB Survey & $\mathrm{X}$ \\
\hline 1122 & $\mathrm{P}$ & LP & Campsite & Clay Loam & Terrace & 10 & $50 \times 25$ & CAR Lackland AFB Survey & $\mathrm{X}$ \\
\hline 1123 & $\mathrm{P}$ & Unknown & LRS & Clay Loam & Terrace & 60 & $50 \times 50$ & CAR Lackland AFB Survey & - \\
\hline 1124 & $\mathrm{P} / \mathrm{H}$ & Unknown & Campsite & Silty Clay & Upland & 600 & $75 \times 40$ & CAR Lackland AFB Survey & $\mathrm{X}$ \\
\hline 1125 & $\mathrm{P}$ & Unknown & Campsite & Silty Clay & Terrace & $0 \dagger$ & $30 \times 30$ & CAR Lackland AFB Survey & $\mathrm{X}$ \\
\hline 1126 & $\mathrm{P}$ & Unknown & Campsite & Silty Clay & Terrace & 35 & $50 \times 20$ & CAR Lackland AFB Survey & $\mathrm{X}$ \\
\hline 1127 & $\mathrm{P}$ & Unknown & Campsite & Silty Clay & Terrace & 75 & $30 \times 25$ & CAR Lackland AFB Survey & $\mathrm{X}$ \\
\hline 1130 & $\mathrm{P}$ & Unknown & LRS & Silty Clay & Terrace & 150 & $30 \times 20$ & CAR Lackland AFB Survey & - \\
\hline 1131 & $\mathrm{P}$ & Unknown & Campsite & Silty Clay & Terrace & 35 & $70 \times 30$ & COE Mitchell Dam Survey & $X$ \\
\hline
\end{tabular}

\begin{tabular}{|c|c|c|}
\hline * & $\mathbf{P} / \mathbf{H}-$ & P- Prehistoric \\
\hline ** & Cultural Component - & - EA-Early Archaic, MA-Middle Archaic, LA-Late Archaic, LP-Late Prehistoric \\
\hline **** & Site Type - & LRS-Lithic Reduction Station \\
\hline ***** & $\begin{array}{l}\text { Distance to Water - } \\
\text { BR - }\end{array}$ & $\begin{array}{l}\dagger \text {-In proximity to water ?-Not stated } \\
\text { X-Burned Rock - Site contains burned rock feature(s) }\end{array}$ \\
\hline
\end{tabular}




\section{Chapter 4:}

\section{Field Methods}

At commencement of the current phase of investigations, recent, significant disturbance had destroyed approximately half of the estimated original site area. A sewer-line trench and associated prospecting trackhoe trench were excavated throughout the northern portion of the site to a depth that would have precluded preservation of the buried cultural deposits.

In an attempt to expose the stratigraphy of the terrace landform and prospect for cultural features, two backhoe trenches were excavated for the current investigations (see Figure 2). Both trenches originated at the bankline of the unnamed tributary and extended inland approximately 5-10 $\mathrm{m}$ to expose representative stratigraphic profiles. These trenches were excavated to unconsolidated gravels, encountered between $80-140 \mathrm{~cm}$ bs.

Based upon TxDOT specifications and previous survey results, as above outlined, five $1-\mathrm{m}^{2}$ test units were placed within the potentially significant, intact portion of the site. Figure 2 depicts the location of these test units in relation to the survey level effort of PAI. All test units were excavated into the unconsolidated gravel sterile substrate.

All horizontal proveniences were maintained in $1-\mathrm{m}^{2}$ levels, with large (ca. $>3 \mathrm{~cm}$ ) artifacts, and temporally diagnostic artifacts point provenienced whenever possible. Vertical excavation levels did not exceed 10 $\mathrm{cm}$ in thickness. Each unit was excavated with arbitrary $10 \mathrm{~cm}$ levels. All excavated sediments were screened through $1 / 4$ " hardware cloth. All cultural material encountered during excavation was collected and recorded on field forms relative to their encountered provenience.

\section{Laboratory Methods}

At the completion of each day, all recovered artifacts and special samples along with associated paperwork were submitted to the CAR laboratory for processing and temporary curation. Processing consisted of artifact washing, a general category sort, cataloging, and entry into Microsoft Access $2000^{\circ}$ database. Subsequent to this initial laboratory processing, the various artifact categories were submitted to specialists for analyses. Following the formal analyses, the results were then incorporated into the final curation database.

Final curatorial processing was conducted in accordance with 36CFR79 (Curation of Federally Owned and Administered Archeological Collections), and other proprietary standards adhered to by CAR, the permanent curatorial facility for the NRHP eligibility test excavations at 41BX1421.

\section{Radiometric Dating}

An attempt was made to recover all charcoal or carbonrich samples encountered during the project. A total of 41 charcoal samples was collected, and each sample was judged to potentially possess adequate depositional integrity for radiometric dating. All samples were point provenienced, where possible. More specifically, the position of each sample both vertically and horizontally, and relative to the specific unit datum, was calculated on a unique, special sample log. Each charcoal sample recovered was placed in an aluminum foil packet and stored in the controlled laboratory setting at CAR. All of the samples selected for radiometric dating were submitted to Beta Analytic, Inc., of Miami, Florida for analysis.

\section{Sediment Susceptibility}

Soil samples were recovered from various locations at the site to test for magnetic sediment susceptibility. The process of measuring the change in magnetic susceptibility of the sediments involves collecting small soil samples at regular intervals throughout the vertical column of a test unit, backhoe trench, or shovel test. The potential change in value of the samples can indicate an increase or decrease in the amount of organic material through the various horizontal levels. Ideally, these peaks in magnetic susceptibility will correspond to an increase in artifact densities.

Samples recovered from the selected columns were placed in plastic bags and stored in the controlled laboratory at CAR until analysis was performed. Prior to analysis, all sediment samples were air dried on a non-metallic surface. After drying, the samples were then 
ground to a uniform grain size using a ceramic mortar and pestle. This was done to standardize particle size and make the material easier to handle and pack into sample containers. The ground samples were placed into a MS2B Dual Frequency Sensor that, in conjunction with a MS2 Magnetic Susceptibility Meter, provided the magnetic susceptibility of each sample. The results of these analyses are presented in Appendix A. 


\section{Chapter 5:}

\section{Stratigraphy}

As depicted in wall profiles of the test units and backhoe trenches (Figures 5-11), the stratigraphy was moderately consistent across the site. With a single exception, three stratigraphic units were encountered in each of the excavated units. The exception was a colluvial gravel lens encountered in the upper aspect of Test Unit 2 (see Figure 6).

The sediments encountered during the current investigations most closely resemble the Frio soil series. The typical profile exhibits an A horizon of very dark grayish brown (10YR 3/2) silty clay loam to approximately $40 \mathrm{~cm}$ bs with a gradual, wavy, and sometimes indistinct boundary. Natural inclusions consist of small to moderate $(20-50 \mathrm{~mm})$ stream-rolled limestone fragments, abundant terrestrial snail shell, and sparse limestone and chert cobbles $(50-70 \mathrm{~mm})$. Root disturbance is moderate to abundant. The tested portion of the site is contained within a relatively dense riparian zone along the tributary. The underlying $\mathrm{Bw}$ horizon consists of a yellowish brown (10YR 5/4) slightly silty clay loam extending to the unconsolidated limestone gravels of the bedrock material and ranging from 70$110 \mathrm{~cm}$ bs with an abrupt wavy boundary. Natural inclusions consist of larger stream-rolled limestone fragments and cobbles $(70-100 \mathrm{~mm})$ and moderate amounts of terrestrial snail shell while moderate root disturbance continues throughout. The basal substrate encountered during the current excavations consists of unconsolidated limestone gravels and large $(60-200 \mathrm{~mm})$ erosional limestone cobbles within a very pale brown (10YR 7/4) clay matrix This substrate is interpreted as the $\mathrm{C}$ horizon across the site.

A probable erosional feature was encountered in the northern portion of Backhoe Trench 2 (see Figure 11). Soil susceptibility samples were extracted horizontally across a plane at $60 \mathrm{~cm}$ bs and vertically down the profile to test the anomaly for potential cultural origin. The results of this analysis are presented in Appendix A.

The colluvial limestone gravel lens exhibited in Test Unit 2 is attributable to the limestone outcropping to the west of the site (see Figure 2). The erosional gravels consist of small to moderate $(20-50 \mathrm{~mm})$ limestone fragments. Natural chert fragments were not associated with the gravels encountered in Test Unit 2.

\section{Stone Tools}

A total of 2,161 chipped stone artifacts was recovered from the manual excavations at 41BX1421. Appendix B presents provenience data for chipped stone, as well as all other artifacts recovered during the manual excavations. Unmodified debitage comprises 99.4 percent $(n=2,148)$ of the assemblage and, under the current scope of work, has not been formally analyzed. The remainder of the chipped stone artifact assemblage consists of dart points $(n=7)$, bifaces $(n=4)$, a core $(n=1)$, and a uniface $(\mathrm{n}=1)$.

The dart point collection is composed of Ensor $(\mathrm{n}=1)$, Fairland $(\mathrm{n}=2)$, Frio $(\mathrm{n}=2)$, Nolan $(\mathrm{n}=1)$, and La Jita $(n=1)$ specimens (Figure 12). The majority $(86 \%[n=6])$ of the recovered dart points occur in Levels 2 through 4 $(10-40 \mathrm{~cm} \mathrm{bs})$. The single exception is a Frio dart point that was recovered from Level $6(50-60 \mathrm{~cm} \mathrm{bs})$ in Test Unit 5 . Table 2 provides a sample of the provenience data. All of the recovered specimens were complete or nearly complete, allowing for positive identification. Note that one of the Fairland (Catalog No. 37-009) and the single Ensor (Catalog No. 7-007) exhibit signs of intensive thermal alteration (see Figure 12d-e).

The four bifaces recovered consist of two proximal fragments, one distal fragment, and one indeterminate edge fragment. Both of the proximal fragments lack any typological or functional attributes, but one of the specimens (Catalog No. 38-009-1) may be an arrow point or an arrow point preform. This specimen is roughly triangular in shape, with maximum lateral basal dimensions of $23.6 \mathrm{~mm}$, and exhibits a maximum thickness of only $3.2 \mathrm{~mm}$. The remaining proximal fragment has a maximum thickness of $7.5 \mathrm{~mm}$ and a maximum lateral basal width of $49.2 \mathrm{~mm}$. The single distal fragment exhibits qualities suggestive of an arrow point or arrow point preform. This distal fragment is 25.6 $\mathrm{mm}$ in length, and has a maximum thickness of $3.3 \mathrm{~mm}$ and a maximum lateral width of $14.9 \mathrm{~mm}$ at the medial point of fracture. 


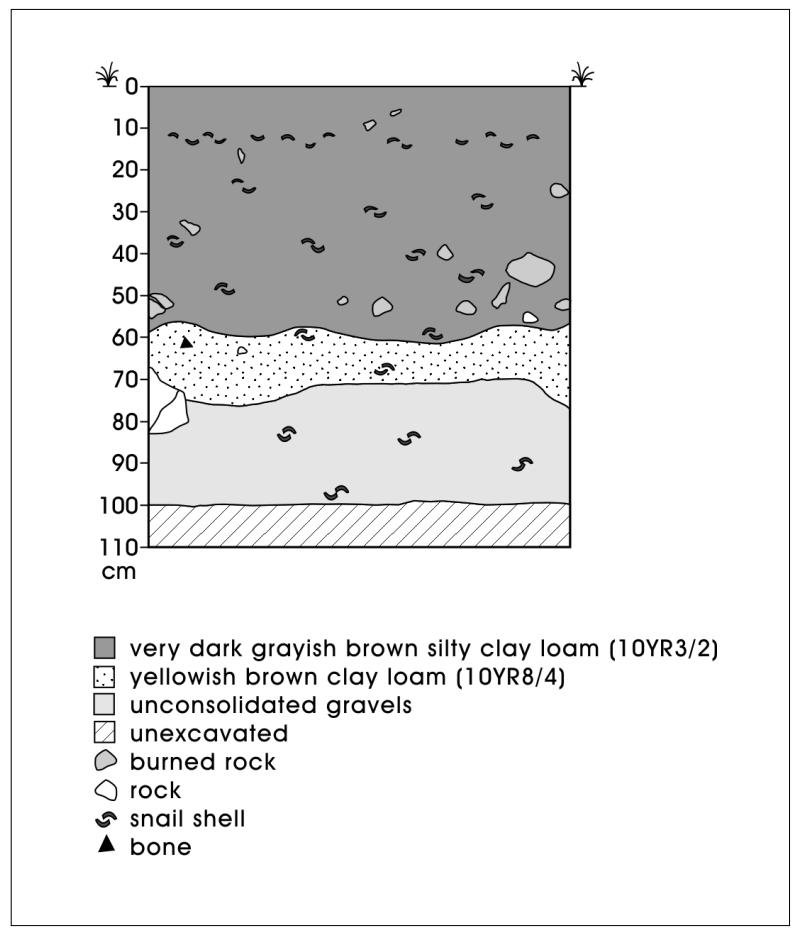

Figure 5. West wall profile of Test Unit 1.

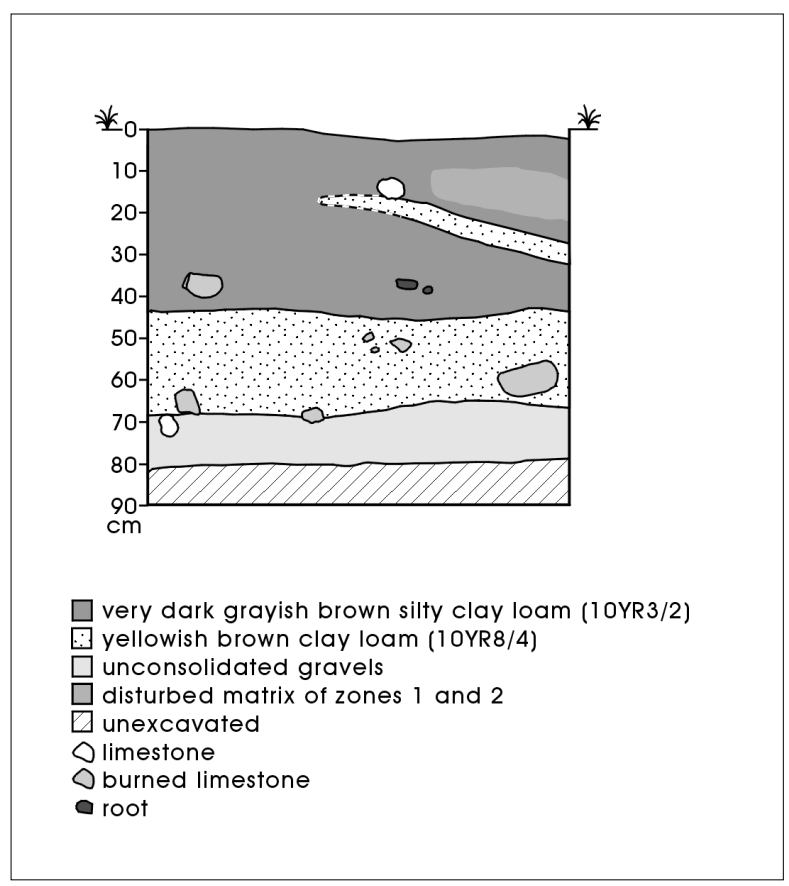

Figure 7. South wall profile of Test Unit 3.

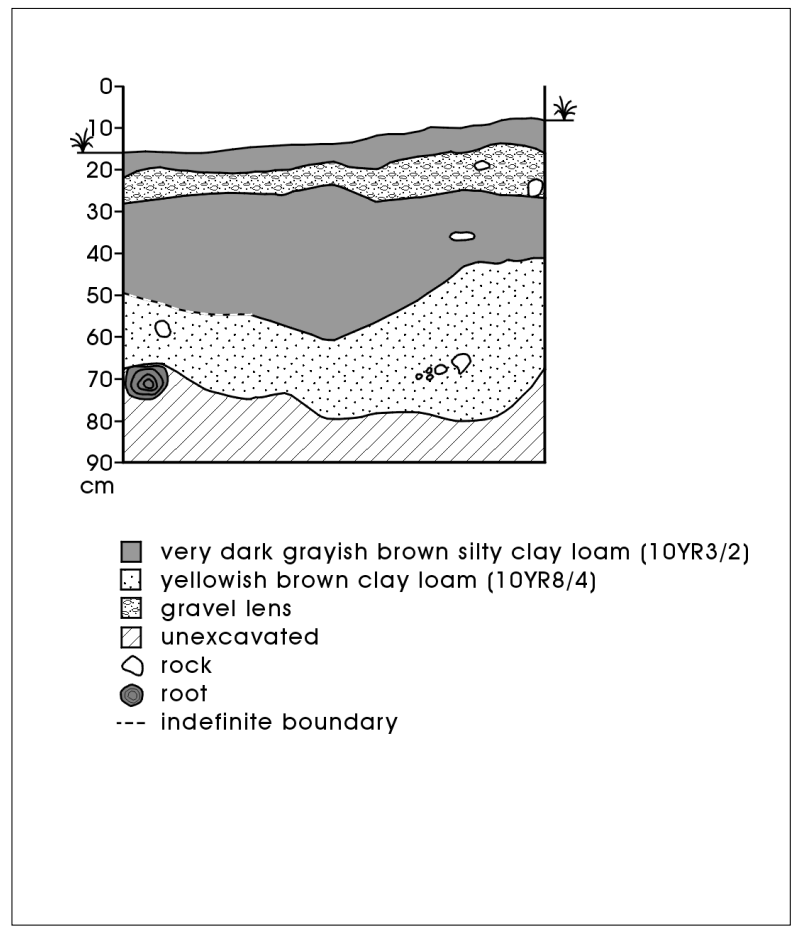

Figure 6. South wall profile of Test Unit 2.

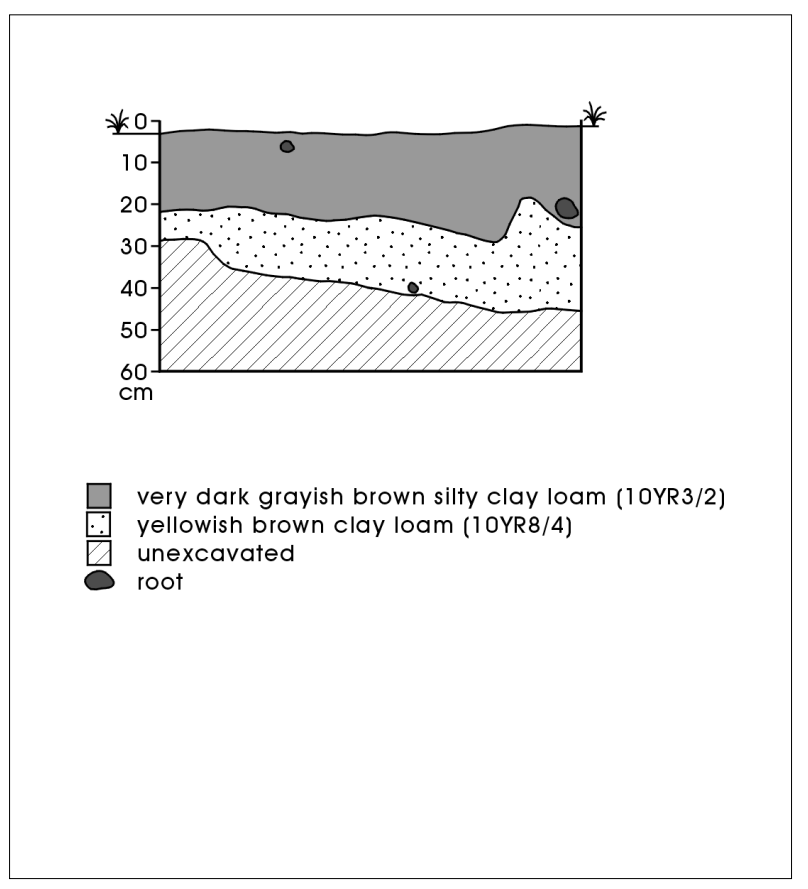

Figure 8. South wall profile of Test Unit 4. 


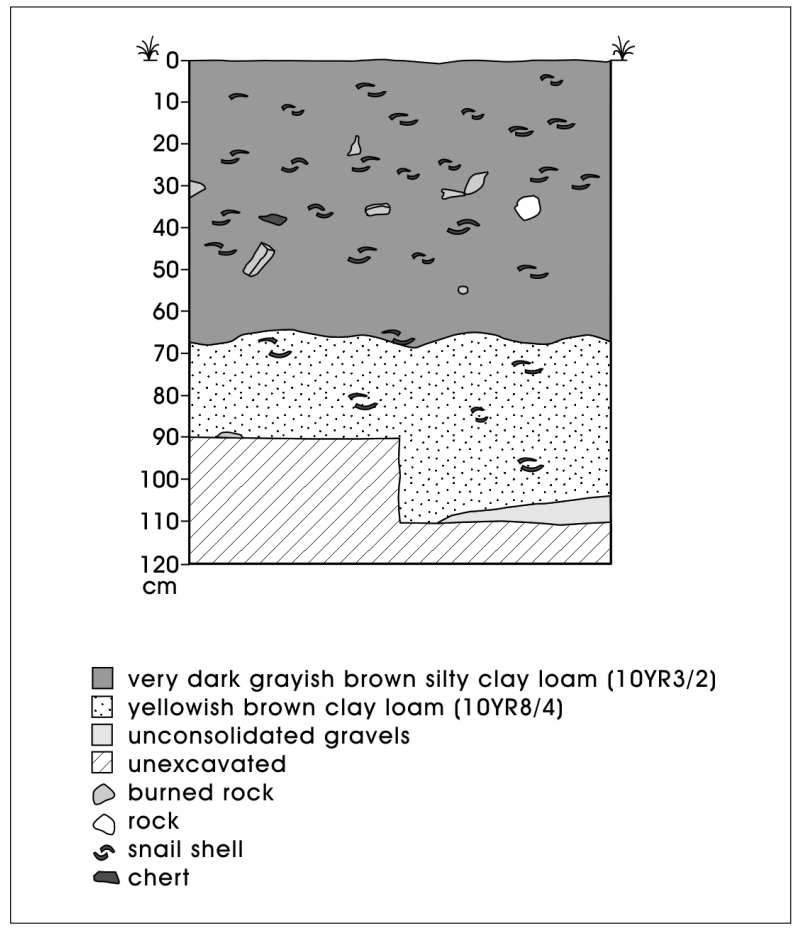

Figure 9. South wall profile of Test Unit 5.

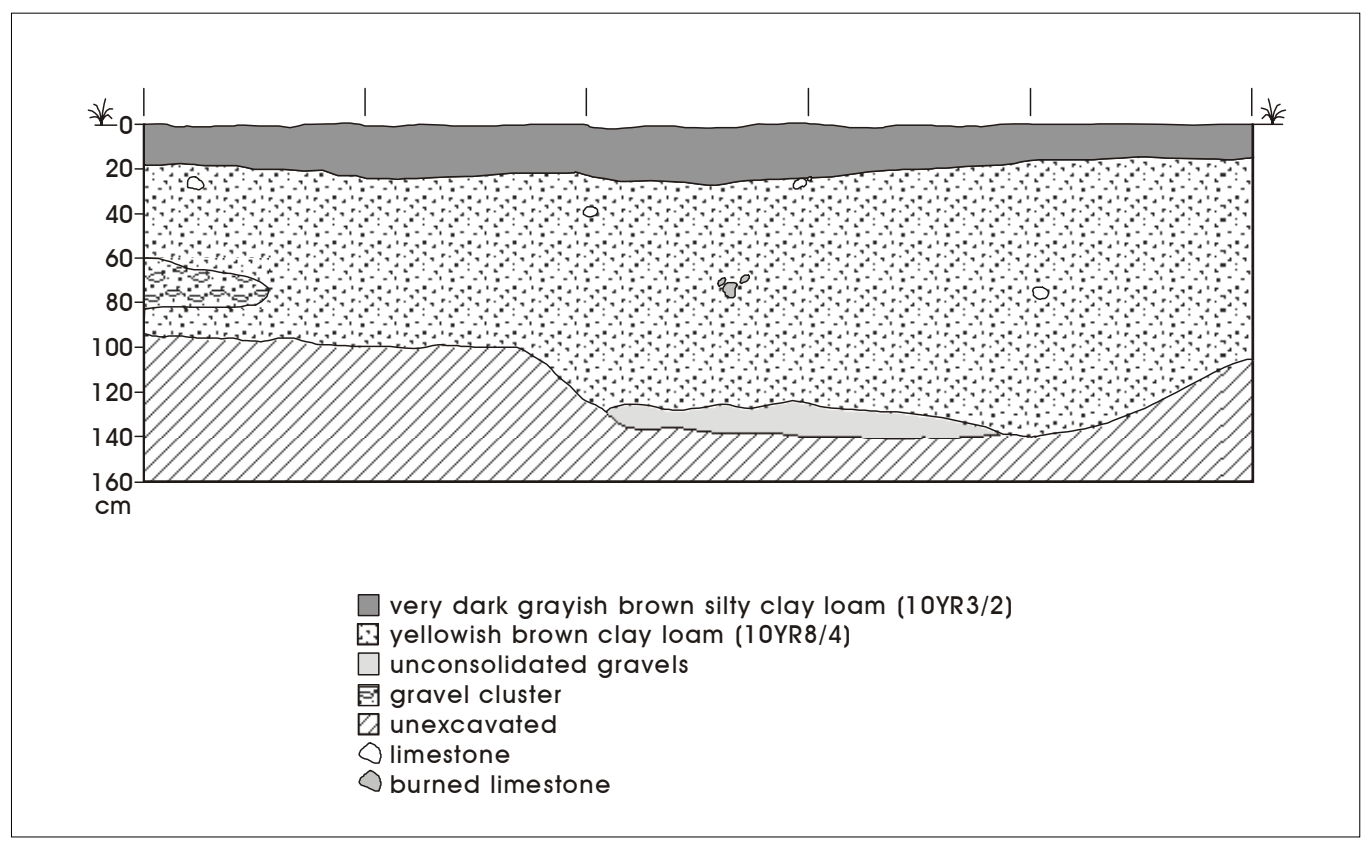

Figure 10. West wall profile of Backhoe Trench 1. 


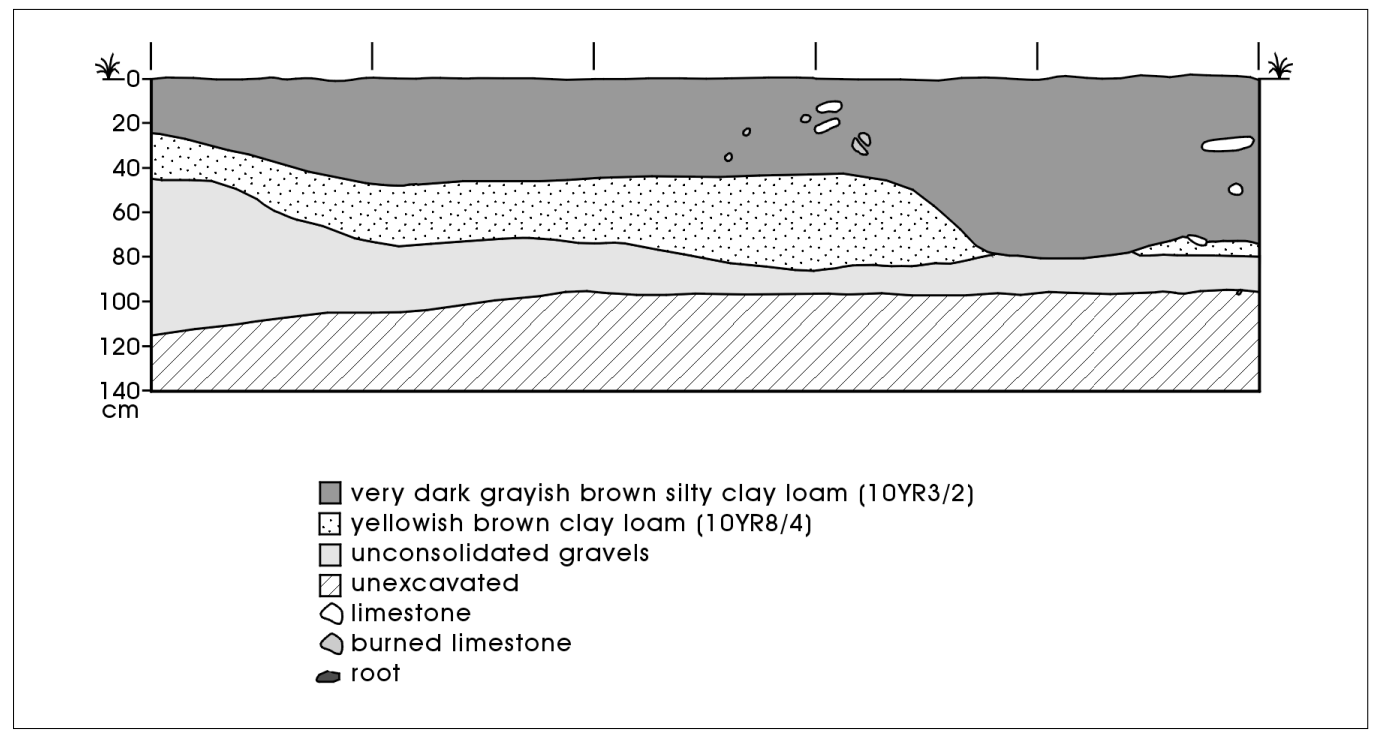

Figure 11. West wall profile of Backhoe Trench 2.

The indeterminate edge fragment appears to have been ground along the bifacial edge, suggestive of the basal portion of a finished or late-stage reduction biface; however, the specimen lacks sufficient dimensions to determine basal or lateral origin.

\section{Aboriginal Ceramics}

Two sherds of Leon Plain ceramics were recovered in a general surface collection of the site. With the exception of the possible arrow point or arrow point preform fragments discussed above, these sherds are the only temporal indicators of a Late Prehistoric component at 41BX1421; no aboriginal ceramics were encountered during mechanical or manual excavations. The sherds are relatively small $(<20 \mathrm{~mm})$, are of different thicknesses (6.5 $\mathrm{mm}$ and $9.1 \mathrm{~mm}$ ), appear to be smoothed or burnished on the exterior, and have a bone-tempered paste. The relatively small size of the ceramic sherds precludes vessel type determination; it remains unclear whether they are from the same or different vessels. The fragments were recovered along the fence line (new Loop 1604 right-of-way), approximately midway between Test Units 1 and 5 (see Figure 2).

\section{Radiocarbon Results}

A total of nine charcoal samples was submitted to Beta Analytic, Inc., for radiometric assays. The samples were recovered during the manual excavations in apparently good stratigraphic context. As only a single feature, the sheet midden, was encountered during the project, the sampling strategy employed focused on the depositional integrity of the vertical column at two separate loci.

Specifically, two units, TUs 1 and 5, were chosen as representing the apparent densest portions of the midden of burned rocks. Charcoal samples were chosen from Levels 2, 4, and 6 in TU 1 and from Levels 2, 3, 4, 5, 8, and 9 in TU 5. Thus, in theory, if chronological sequencing is evident in the two selected columns, then, by proxy, depositional integrity would be proven.

Table 2 presents the corrected radiocarbon ages of the nine samples, along with their Beta Analytic sample numbers, provenience information, feature association, material dated, and cluster groupings. Additional information on these nine samples can be found in Appendix C. The cluster groupings are derived from 


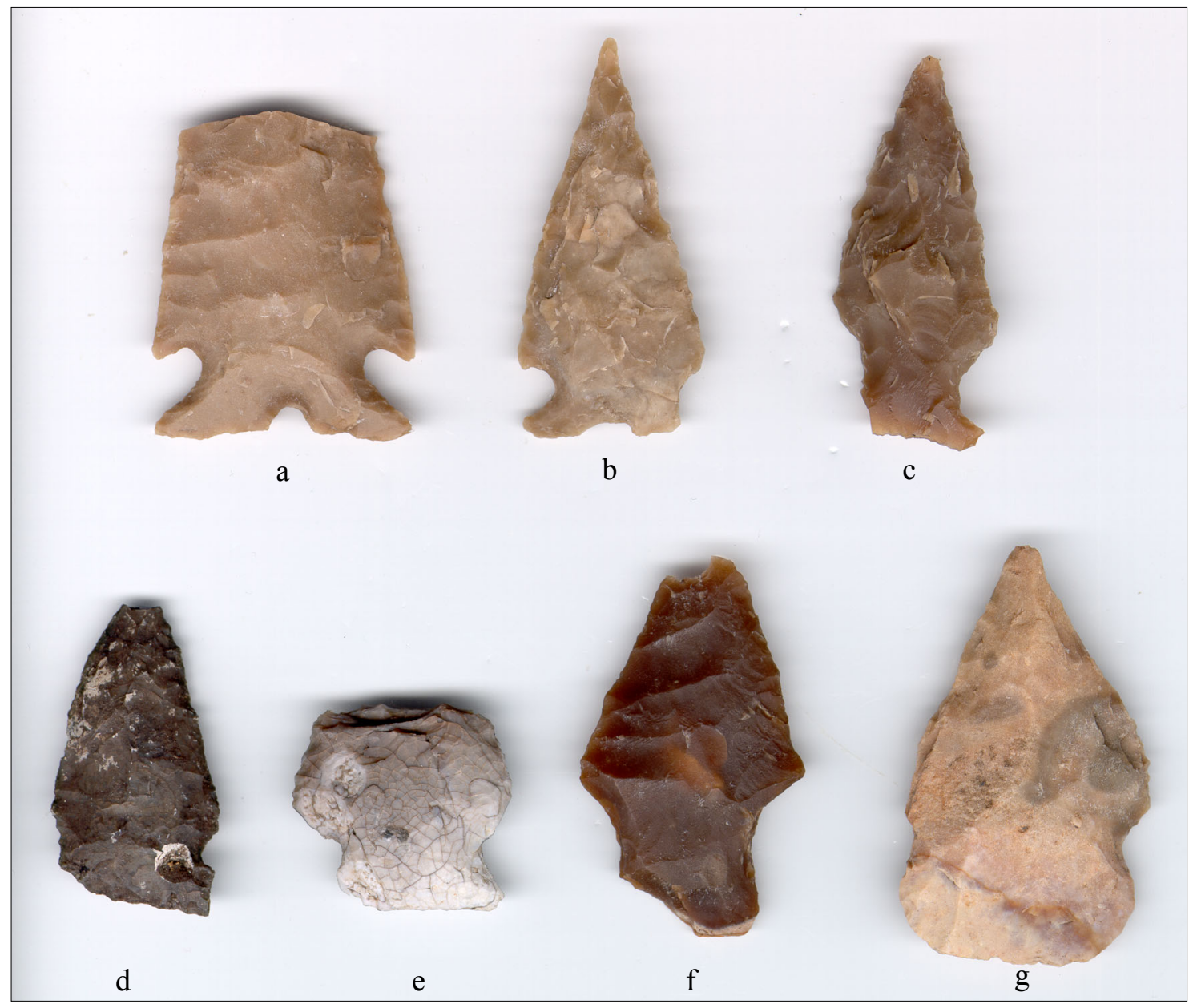

Figure 12. Dart points recovered from 41BX1421. a-b) Frio; c-d) Fairland; e) Ensor; f) Nolan; g) La Jita.

Table 2. Radiocarbon samples from Medio Creek testing (41BX1421)

\begin{tabular}{|c|c|c|c|c|c|c|c|l|c|l|}
\hline $\begin{array}{c}\text { Cluster } \\
\text { Groups }\end{array}$ & Sample \# & Catalog \# & Beta \# & Unit & Level & Feature & Weight & Class & Age BP & Diagnostic \\
\hline 1 & 1 & $06-006$ & 163782 & 1 & 2 & - & 2.30 & Charcoal & $190+/-90$ & Ensor (n=1), Level 3 \\
\hline 2 & 2 & $08-002$ & 163783 & 1 & 4 & - & 4.00 & Charcoal & $1070+/-60$ & Frio (n=1); La Jita (n=1) \\
\hline 3 & 3 & $11-002$ & 163784 & 1 & 6 & 2 & 0.70 & Charcoal & $1620+/-40$ & \\
\hline 1 & 4 & $37-002$ & 163785 & 5 & 2 & - & 3.00 & Charcoal & $80+/-40$ & Fairland (n=2) \\
\hline 1 & 5 & $38-001$ & 163786 & 5 & 3 & - & 2.00 & Charcoal & $270+/-90$ & \\
\hline 2 & 6 & $39-003$ & 163787 & 5 & 4 & 3 & 0.98 & Charcoal & $1020+/-50$ & \\
\hline 2 & 7 & $42-005$ & 163788 & 5 & 5 & - & 2.50 & Charcoal & $1190+/-40$ & Frio (n=1), Level 6 \\
\hline 2 & 8 & $45-004$ & 163789 & 5 & 8 & - & 0.45 & Charcoal & $1110+/-40$ & \\
\hline 4 & 9 & $46-002$ & 163790 & 5 & 9 & - & 2.50 & Charcoal & $3060+/-40$ & \\
\hline
\end{tabular}


clustering procedures suggested by Ward and Wilson (1978; Wilson and Ward 1981). All radiocarbon dates from the excavation block were tested using Ward and Wilson's Case II assumptions and the DSPLIT radiocarbon program (Kintigh 1992:83-85). Four different groups were identified by this procedure, and the cluster group identifications are ranked from 1, the most recent group, to 4, the oldest group. Comparison of the cluster groupings by levels and units suggest a continuous depositional sequence with no anomalous exception. The four groups proceed in chronological order from youngest to oldest downward through the vertical column. It is evident, then, based on these data that the samples are from intact deposits.

Reference to Figure 13 (see also Table 2), which plots the probability curves from each of the dates using the $\mathrm{OxCal}$ calibration program (Ramsey 2000), reinforces that impression. Individual dates are significantly different by depth in comparison among the different clusters by unit. Within TU 1, the oldest date is from Level 6, which is roughly 550 years older than the Level 4 date, and roughly 1,430 years older than the Level 2 date. The results from TU 5 are quite similar, with the exception of Sample \#9 (Catalog No. 46-002), which was recovered from the unconsolidated gravel substrate, predating the aggradation of the terrace deposits at this locale. Less and excepting this oldest date reveals that occupation appears to have been fairly consistent with the rapid depositional sequence evidenced in Levels 8 through 4 . The three dates recovered from these levels are statistically indistinguishable from one another. Within TU 5, Level 4 is roughly 750 years older than the Level 3 date, and roughly 940 years older than the Level 2 date.

\section{Chronological Framework}

The uniqueness of this report is its assessments of the artifact assemblage and the site as a whole from two very different perspectives. The interim version of the report was written prior to the approval of radiometric dating of charcoal samples. Consequently, the interpretation of the chronology and depositional integrity was derived only from the presence of diagnostic artifacts, the stratigraphic context in which these diagnostic artifacts were recovered, and the apparent integrity of the various strata documented through the manual excavation. Subsequent to production of the interim report, however, approval was granted to run a series of radiometric dates to better assess the integrity of the site. The results of these two interpretations are provided below.

\section{Interim Results}

The tentative chronological assessment of 41BX1421 was based on temporally diagnostic artifacts and their respective depositional context. A total of 41 charcoal samples was recovered during the manual excavations in apparently good stratigraphic context. Abundant samples of terrestrial snail shell were recovered from vertical and horizontal proveniences. Suggestions were made to conduct radiometric assays of a select portion of the charcoal samples and amino acid racemization analysis of select vertical column samples of the land snail shell to provide substantive additional data for assessing the temporal and depositional integrity of the cultural deposits.

The majority $(71 \%[n=5])$ of the dart point assemblage temporally placed 41BX1421 within Johnson and Goode's (1994) Late Archaic II period at approximately 2000 BP. The Ensor-Frio-Fairland component is well represented at 41BX1421, with point styles of each of the three types present. For Central Texas, Collins considers these three point types to be contemporaneous and, together as a point style interval, constituting one of the later intervals of the Late Archaic period (Collins 1995:384, Table 2). At the Panther Springs Creek site (41BX228), 41BX300, 41BX1, and the Cibolo Creek Crossing site (41BX377) these point types have been excavated in similar contexts with good integrity (e.g., Black and McGraw 1985; Katz 1987; Lukowski 1988; Kibler and Scott 2000, respectively). The Ensor-FrioFairland component straddles the latter part of the Uvalde Phase and is a portion of the representative artifact assemblage of the succeeding Twin Sisters Phase (Prewitt 1981:81, Figure 4). During these phases, Prewitt (1981:81) suggests the decline of burned rock middens with adaptation becoming more diverse. Indeed, the occurrence of artifacts diagnostic of the Ensor-FrioFairland component at 41BX1421 is vertically positioned slightly above the burned rock feature at the site (Tables 3 and 4), interpreted as a burned rock sheet midden. 


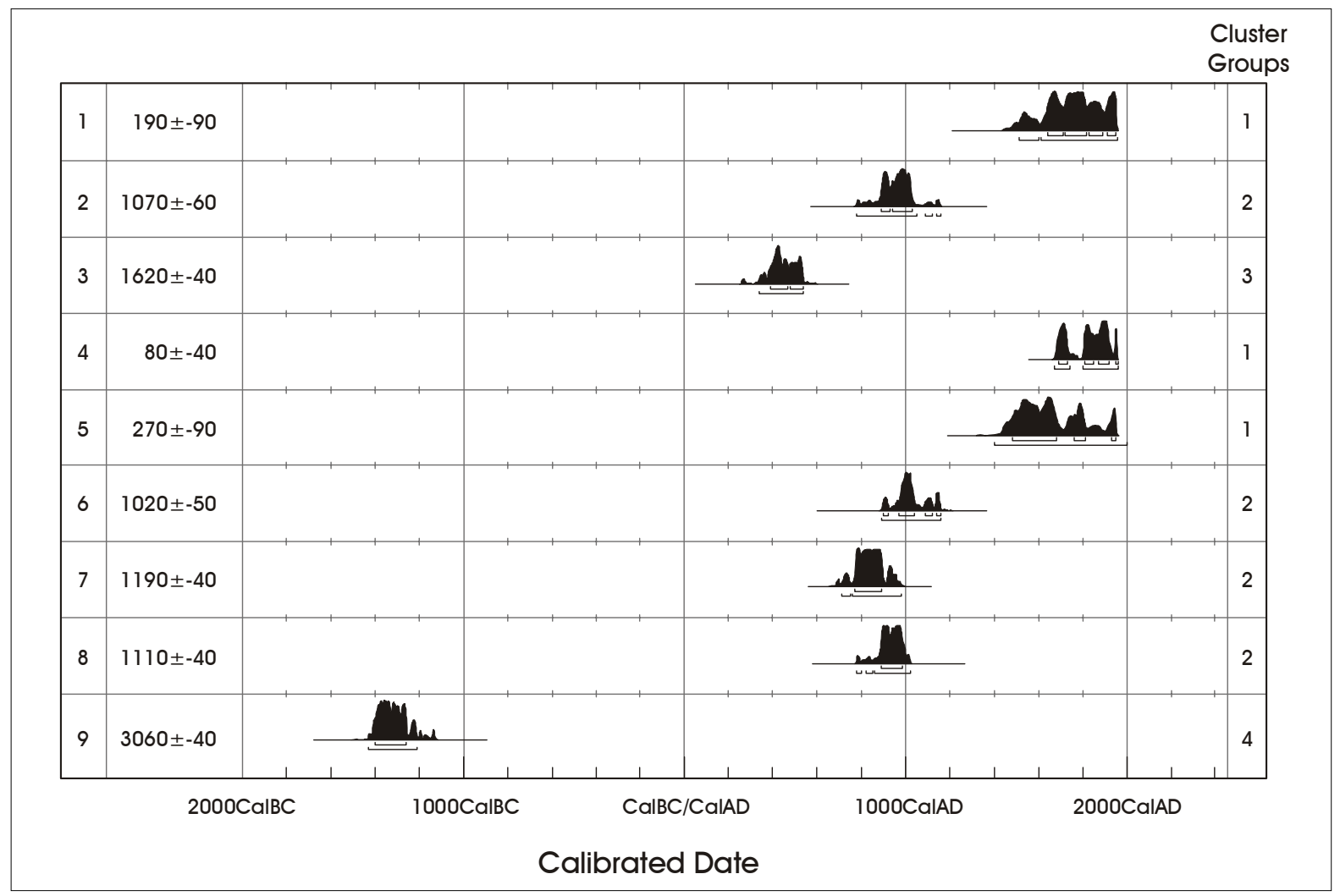

Figure 13. Calibrated radiocarbon dates from $41 B X 1421$.

Table 3. Distribution of projectile points by unit and level

\begin{tabular}{|c|c|c|c|c|c|c|}
\hline Unit & Level & Depth & Catalog No. & Class & Count & Type \\
\hline Test Unit 5 & 2 & $10-20 \mathrm{~cm}$ & $36-006$ & Point & 1 & Fairland \\
\hline Test Unit 5 & 2 & $10-20 \mathrm{~cm}$ & $37-009$ & Point & 1 & Fairland \\
\hline Test Unit 1 & 3 & $20-30 \mathrm{~cm}$ & $7-007$ & Point & 1 & Ensor \\
\hline Test Unit 1 & 4 & $30-40 \mathrm{~cm}$ & $8-009$ & Point & 1 & Frio \\
\hline Test Unit 1 & 4 & $30-40 \mathrm{~cm}$ & $8-007$ & Point & 1 & La Jita \\
\hline Test Unit 2 & 3 & $30-40 \mathrm{~cm}$ & $17-005$ & Point & 1 & Nolan \\
\hline Test Unit 5 & 6 & $50-60 \mathrm{~cm}$ & $43-007$ & Point & 1 & Frio \\
\hline
\end{tabular}

Table 4. Vertical distribution of artifacts

\begin{tabular}{|c|c|c|c|c|}
\hline Level & Bone & BR & Debitage & Diagnostic \\
\hline 1 & 3 & 4127 & 42 & 1 \\
\hline 2 & 66 & 7102 & 433 & 1 \\
\hline 3 & 19 & 16248 & 276 & 1 \\
\hline 4 & 81 & 41908 & 776 & 3 \\
\hline 5 & 50 & 29545 & 282 & 0 \\
\hline 6 & 14 & 79620 & 189 & 1 \\
\hline 7 & 6 & 15778 & 82 & 0 \\
\hline 8 & 3 & 15619 & 42 & 0 \\
\hline 9 & 2 & 1490 & 20 & 0 \\
\hline 10 & 0 & 473 & 4 & 0 \\
\hline 11 & 0 & 0 & 2 & 0 \\
\hline Totals & 244 & 211910 & 2148 & 7 \\
\hline
\end{tabular}


While the recovered diagnostic artifacts best represent the Late Archaic period, artifacts diagnostic of other temporal periods were also present. The nature of the burned rock feature exhibited in the lower levels of Test Units 1, 3, and 5 is best ascribed to the Middle Archaic period (Prewitt 1981:73). While the nature of this concentration remained unclear, a similar scatter was excavated at 41BX300 (Katz 1987), and no other definable features were encountered. It was speculated that the concentration at $41 \mathrm{BX} 1421$ could be similar to that at 41BX300 (Katz 1987:179-180), representing an area primarily used as a "community dump." As such, the area would not contain other features associated with occupation.

The recovery of a single La Jita dart point in the upper aspect of the sheet midden at $35-40 \mathrm{~cm}$ bs in Test Unit 1 was the only artifact diagnostic of the Middle Archaic. The specimen is heavily reworked with alternate beveling of the blade (Figure 14). The Nolan dart point, although also a diagnostic of the Middle Archaic, was recovered from the colluvial gravel lens encountered in Test Unit 2, located at the base of the exposed limestone formation. As the sheet midden did not extend west to the location of Test Unit 2, the Nolan point was not considered directly associated with the burned rock concentration itself; however, the interim report left the possibility open for the Nolan to be associated with the occupation(s) responsible for the formation of the burned rock concentration.
The recovery of the two Leon Plain ceramic sherds in the surface collection suggested an occupation of the Late Prehistoric at 41BX1421. As discussed in the interim report, the only likely indicators of a Late Prehistoric component recovered in the mechanical or manual excavations were the two possible arrow point or arrow point preform fragments (Catalog No. 38-009-1 recovered in TU-5, Level 3 [20-30 cm bs], and Catalog No. 39-011 recovered in TU-5, Level 4 [30-40 cm bs]). It was noted that the presence of the ceramic sherds atop ground surface, however, suggested a discrete, shallowly buried Late Prehistoric component that may have been all but obliterated with construction activities.

\section{Final Results}

The final chronological assessment of 41BX1421 is based on temporally diagnostic artifacts and the radiometric assays of nine charcoal samples, all of which were recovered during manual excavation in apparently good stratigraphic context.

Various authors (i.e., Black 1989, Hester 1995) note the similarity of South Texas and Central Texas in regard to the latter two periods of prehistory. Indeed, in light of the geographic locus of 41BX1421 at the base of the Balcones Escarpment, one could argue placement in either of these two archeological regions of Texas. The location of the site at the confluence of the two streams and at the foot of one of the more abundant sources of

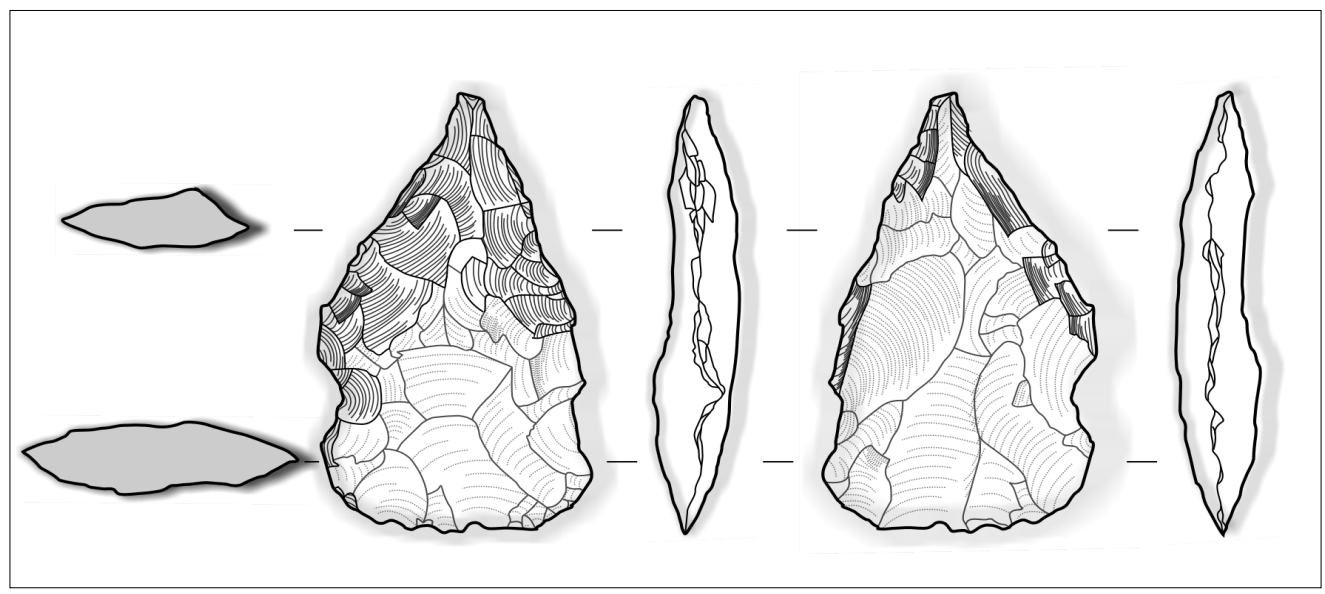

Figure 14. La Jita dart point recovered from Level 4, TU 1 at $41 B X 1421$.

Views from L-R: dorsal, right lateral, ventral, and left lateral. Note reworking along left lateral edge in dorsal view and right lateral edge in ventral view. 


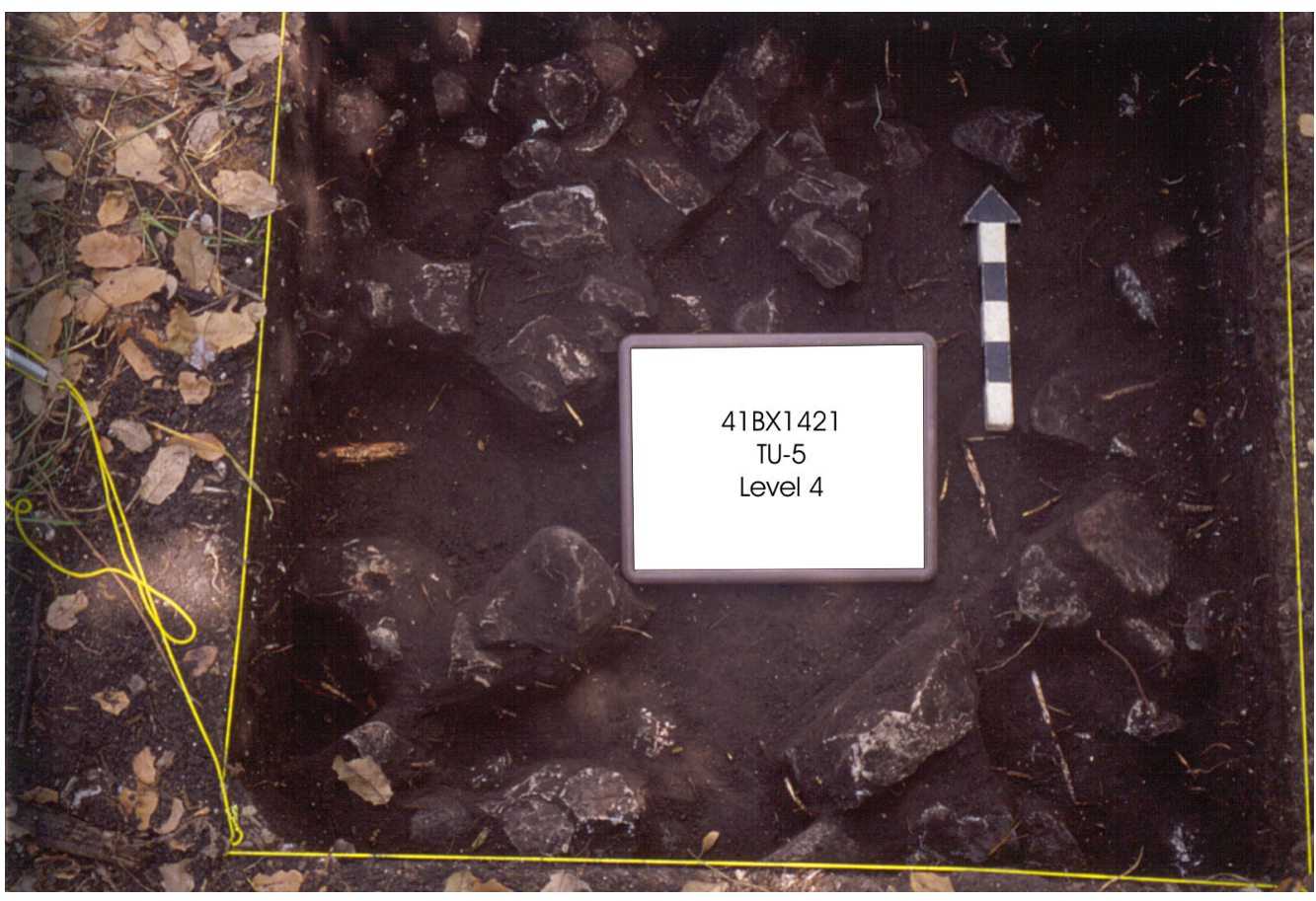

Figure 15. Photograph of sheet midden in Level 4, TU 5 at 41BX1421. View is to the north.

lithic material in the state describes many of the over 1,000 recorded prehistoric archeological sites in Bexar County.

Interpreted as an open campsite, the recovered archeological assemblage from 41BX1421 contains temporally diagnostic stone tools of the Middle Archaic and Late Archaic II. Two arrow point preforms and two sherds of Leon Plain ceramics indicate a Late Prehistoric component, as well. The single feature encountered during the 2001 excavations is a sheet midden comprised primarily of burned limestone cobbles encountered in Level 4 of TU 5 (Figures 15 and 16), Level 6 of TU 1 (Figures 17 and 18), and again in Level 6 of TU 3 (Figures 19 and 20). This feature, in concert with the two Middle Archaic dart points, suggests an incipient burned rock sheet midden. These features, and the subsequent abandonment thereof, are index markers for Prewitt's (1981:79) Clear Fork Phase of the Middle Archaic for Central Texas.

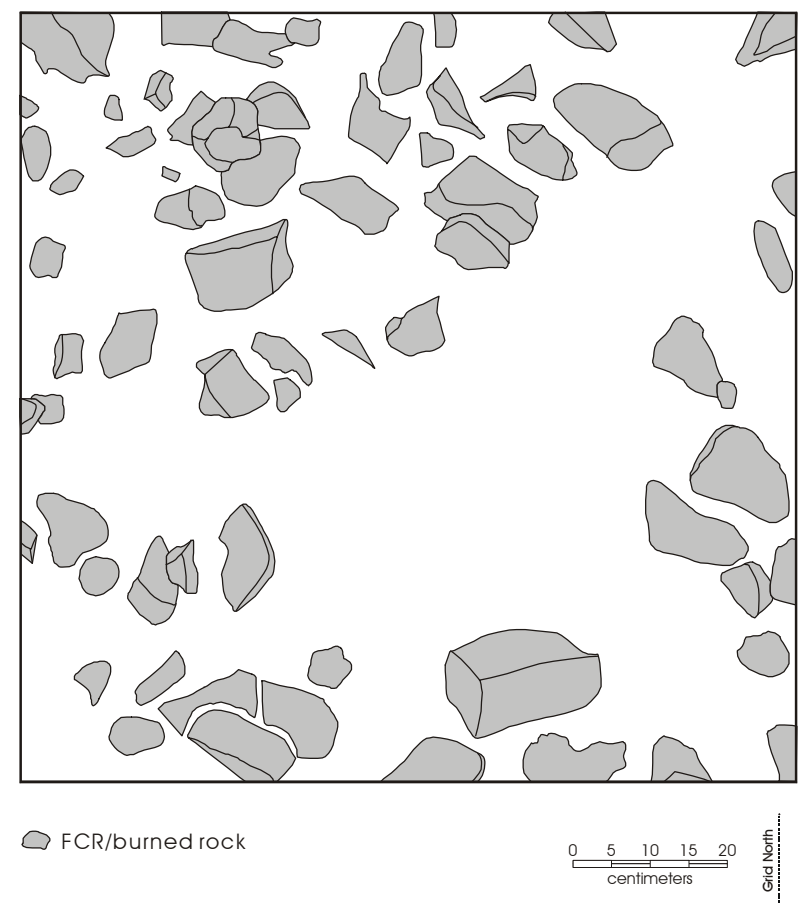

Figure 16. Plan view of sheet midden in Level 4, TU 5 at $41 B X 1421$. 


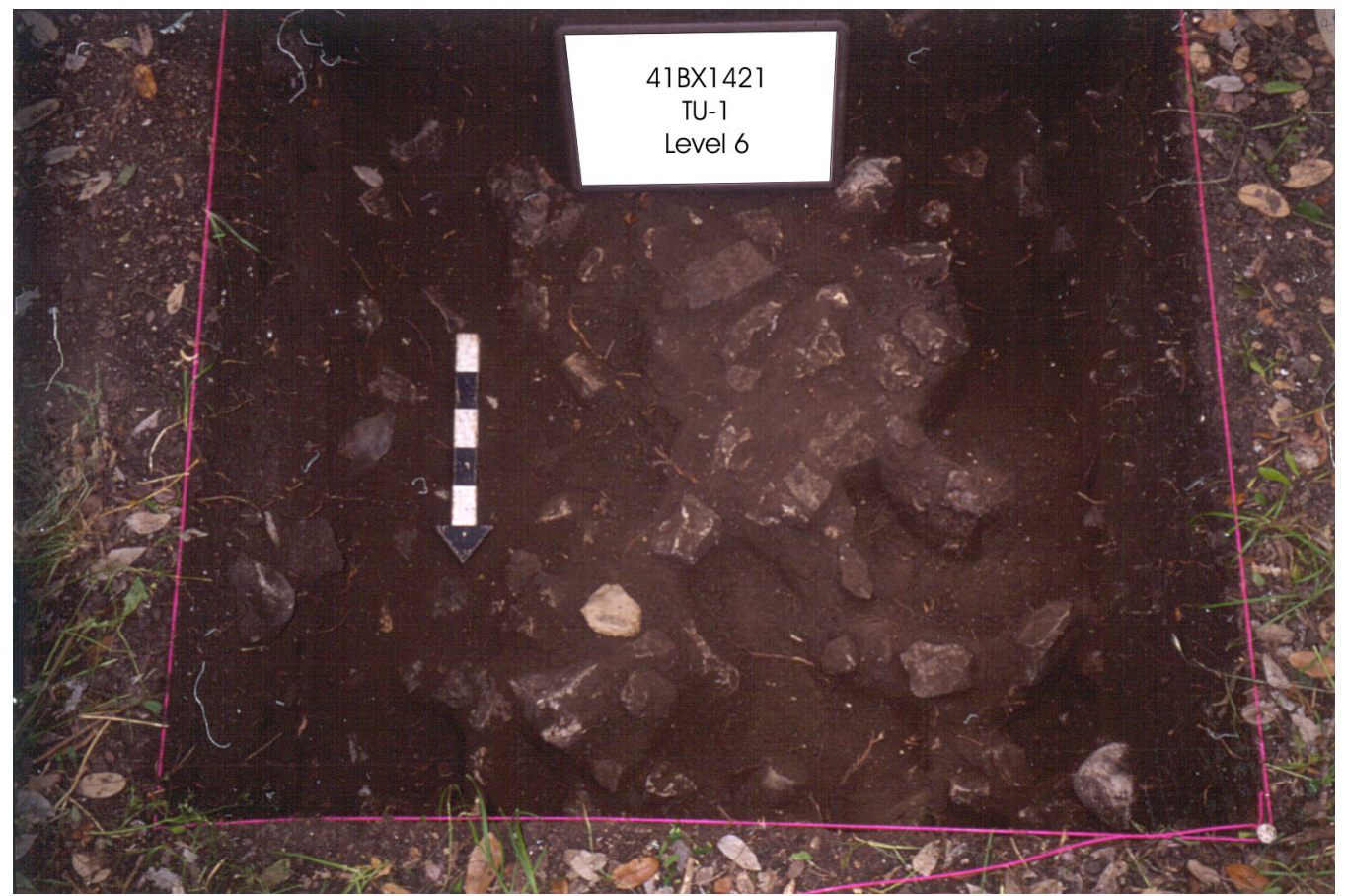

Figure 17. Photograph of sheet midden in Level 6, TU 1 at 41BX1421. View is to the south.

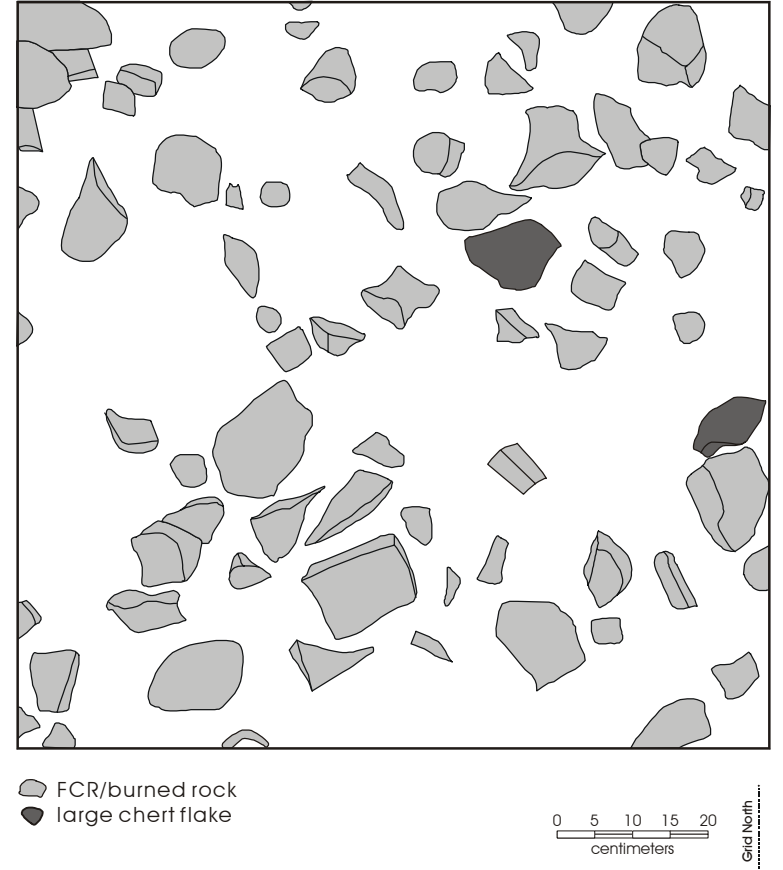

Figure 18. Plan view of sheet midden in Level 6, TU 1 at $41 B X 1421$.
Sans the radiocarbon results (Appendix C), diagnostics recovered within the deposits form, what appears to be, a simple chronological sequence at this terrace locale. A Middle Archaic culture initially occupied the site some 5,000 to 6,000 years ago, forming the incipient burned rock sheet midden and depositing the Nolan and La Jita dart points, both of which are generally accepted as horizon markers for the Middle Archaic. Following the abandonment of the site and subsequent alluvial deposition, Late Archaic II folk reoccupied the site and left behind Ensor, Frio, and Fairland dart points. Finally, a Late Prehistoric people made the final occupation of the site leaving behind some arrow point preforms and debris from a ceramic vessel. Again, based upon temporally diagnostic artifacts alone, this seems a plausible story.

The results of the radiometric assays chronicle a quite different scenario, though. More specifically, the radiometric assays indicate a predominately Late Prehistoric occupation of the site, with an earlier, less intensive Late Archaic occupation. The samples analyzed 


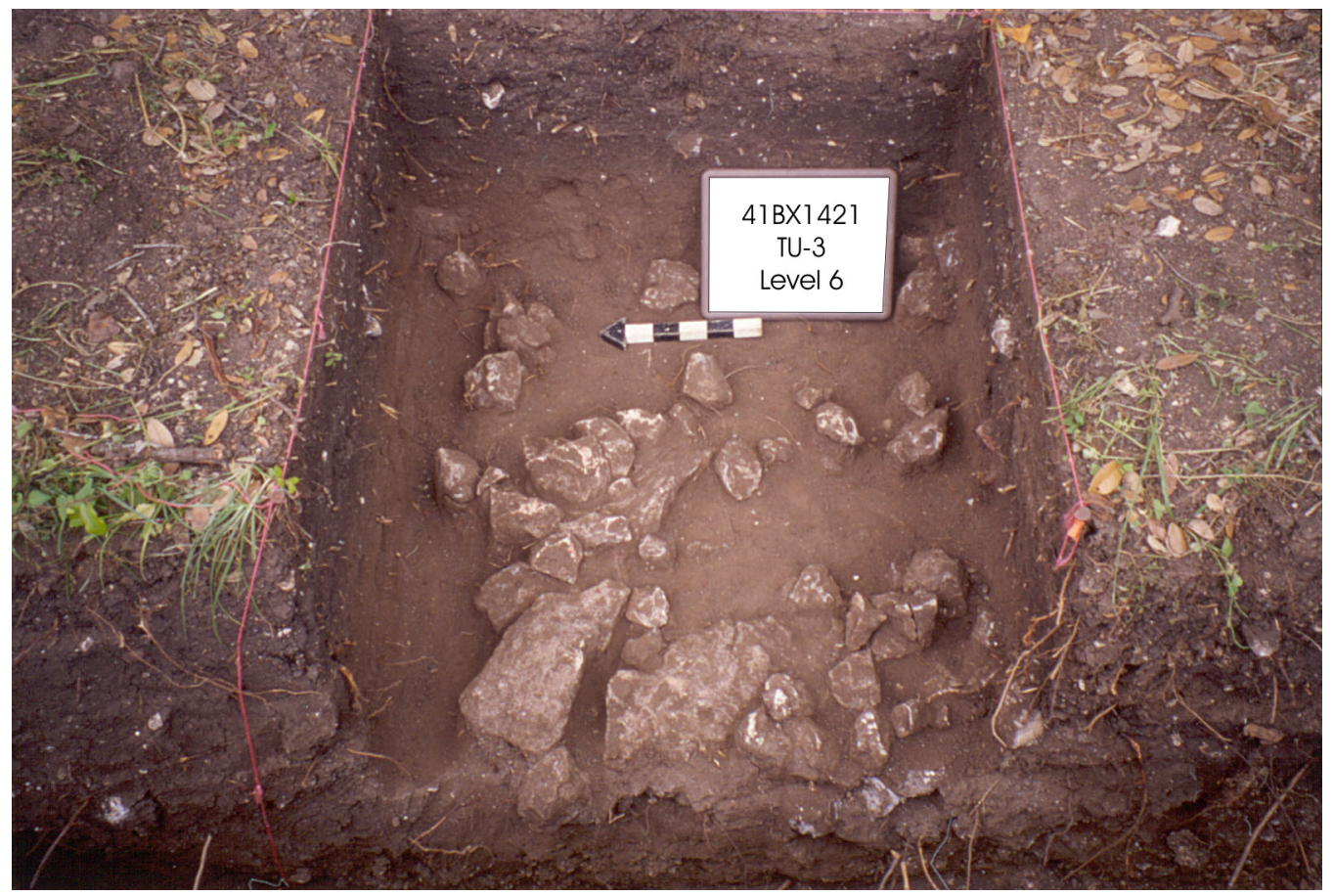

Figure 19. Photograph of sheet midden in Level 6, TU 3 at 41BX1421. View is to the east.

were recovered from two test units located at the southeastern portion of the extant remnant of the site and along the unnamed tributary to Medio Creek. The dating strategy employed attempted to focus on as complete vertical columns of charcoal samples as could be wrought from the apparent densest portion of the site. The two columns tested produced a chronological sequencing that indicates, chronological and, by extension, depositional integrity of the terrace site.

The tendency to ascribe the period change from the Late Archaic to the Late Prehistoric is aptly attributed to the advent of more advanced weaponry technology, namely the bow and arrow. It would be shortsighted, however, to infer that the technology of the atlatl and dart, equipment that spanned millennia, was immediately abandoned with the introduction of the bow. Indeed, dart points comprised roughly one-quarter of the diagnostic assemblage at Cooper Lake in east Central Texas (Fields 1995:310). Dart points such as Gary and Kent were recovered alongside Scallorn, Catahoula, and Alba arrow points and varieties of aboriginal pottery (Fields 1995).

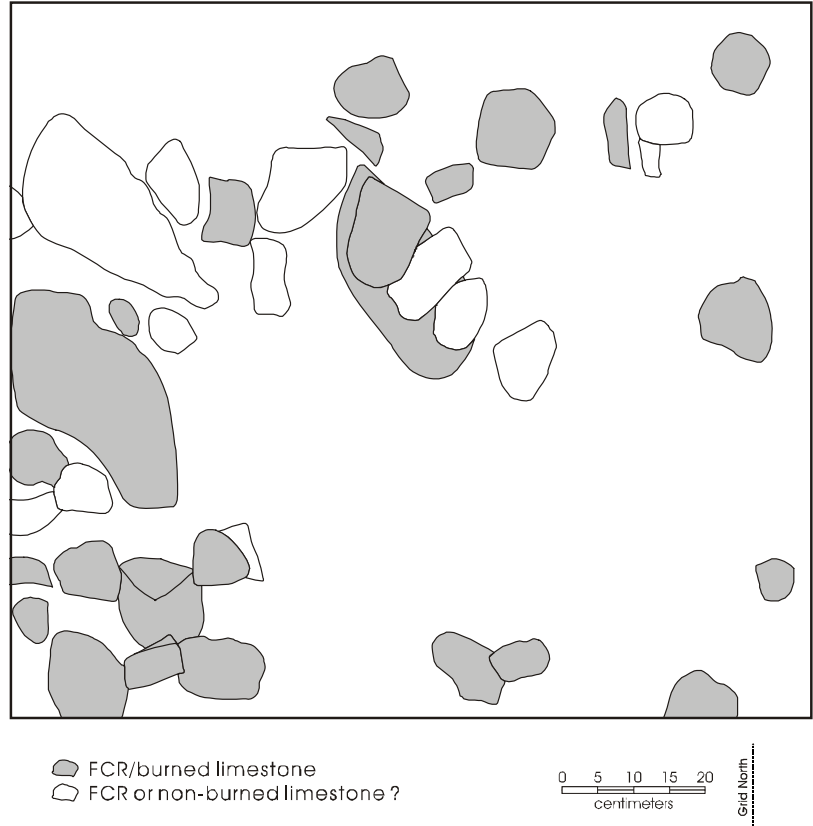

Figure 20. Plan view of sheet midden in Level 6, TU 3 at $41 B X 1421$. 
As is generally accepted, Fields (1995) places the commencement of the Cooper Lake Late Prehistoric period at roughly $1200 \mathrm{BP}$.

Similarly, most archeologists adhere to this time interval of between 1300 and $1200 \mathrm{BP}$ as the terminus of the Late Archaic. This author does not intend to deviate from these absolute dates, rather, suggest a closer look at the relative dates of index -temporally diagnostic artifacts of the latter part of the Late Archaic and the early part of the Late Prehistoric, or, more conveniently, the Transitional Archaic. More specifically, an attempt will be made, based on the artifact assemblage and radiometric dates of 41BX1421, to reevaluate the rigid assignment of point typologies as diagnostic to only one temporal period.

Numerous testing and mitigation publications reporting on projects wherein Late Archaic dart points were recovered in context with Late Prehistoric materials were reviewed for this brief synthesis. However, with preemptive foresight, only those sites in which a definitive association of the two via an isolable component will here be referenced. Aside from the east Central Texas reference above, the discussion will be limited to the southern Central Texas and South Texas archeological regions.

An excerpt from Hester's (1995:443) recent summary of the prehistory of South Texas best introduces the conundrum at hand:

The earlier parts of the Late Prehistoric are less clear [than the Toyah interval]. For example, "dart points" such as Ensor, Matamoros, Catán, and Zavala often occur in what are otherwise Late Prehistoric contexts, some even in very late contexts. These are small points and surely could have been used with the bow and arrow. Whether they were "recycled" by Late Prehistoric hunters, or were made and used as part of the bow and arrow system is hard to tell (evidence for the latter comes from 41LK106 [Creel et al. 1979]).

A review of the artifact assemblage recovered from 41LK106 indicates where two Matamoros dart points were recovered in association with 41 undecorated, bone tempered ceramic sherds (Creel et al. 1979:14). While the materials were associated with a hearth feature, no charcoal was encountered during the excavations to directly date the feature. Cross-dating of the ceramics with a site in the Choke Canyon investigations containing similar dart points and ceramics, Creel et al. (1979:28) suggest a date of roughly $700 \mathrm{BP}$ for that component at $41 \mathrm{LK} 106$.

Excavations conducted at the Panther Springs Creek site (41BX228) in the northern portion of Bexar County revealed several proveniences containing both dart points and Late Prehistoric materials (Black and McGraw 1985). Most extensive in Areas A, B, and C, the occurrence of dart points in the Late Prehistoric strata were apparently due to disturbance in each instance (Black and McGraw 1985:242, 248, 251). In each area, at least one point type of the Ensor-Frio-Fairland was recovered in context with two or more arrow points. Interestingly, in Area I, which was considered to represent the least disturbed stratified deposits, the pattern of dart points alongside arrow points is quite similar (Black and McGraw 1985:258). In this case, three Ensor dart points were recovered in association with two Scallorn arrow points and one Edwards arrow point. A key contribution to the regional chronology afforded by this study was the establishment of the Local Period temporal designations. Specific to 41BX1421, Local Period 9 appears most relevant, as the authors describe the Frio and Ensor dart point types temporally diagnostic of the Transitional Archaic. Specifically, they state, "At 41BX228, a number of dates ranging from [1040930 BP] may be applicable to Local Period 9" (Black and McGraw 1985:105). Fortunately, a charcoal sample recovered in association with a Frio dart point in Level 3 of XU N108W104 at 41BX228 provided an uncorrected radiocarbon date of $1110 \pm 110$ BP to corroborate their assertion.

Intensive investigations in Uvalde County have recorded at least five sites where dart points represent a portion of the overall Late Prehistoric artifact assemblage. Three of these sites (41UV45, 41UV47, and 41UV48) were investigated along the Leona River watershed between the Nueces and Frio Rivers at the base of the Balcones Escarpment (Lukowski 1987). Excavations at 41 UV45 recovered a Leon Plain sherd in association with an Ensor dart point (XU 47-22, Level 1). Charcoal recovered in Level 2 of the same unit produced an uncorrected 
radiocarbon date of $410 \pm 50 \mathrm{BP}$. One Perdiz arrow point and one Marshall dart point were also recovered from Level 2 of XU 47-22. Level 3 contained one Edwards arrow point, one Ensor dart point, two Frio dart points, and one Marcos dart point. A charcoal sample from Level 4 returned an uncorrected radiocarbon date of $1060 \pm 60 \mathrm{BP}$.

Site 41UV47 exhibited a diversity of dart points and arrow points sharing identical provenience. In Area A, the upper $70 \mathrm{~cm}$ (Levels 1 through 7) of deposits contain 19 typeable arrow points and five typeable dart points, with the majority of the assemblage occurring in the upper $40 \mathrm{~cm}$. Level 1 contained six Perdiz arrow points, one Scallorn arrow point, and one Fairland dart point. Level 2 contained three Perdiz arrow points and three Scallorn arrow points. Level 3 produced one Scallorn arrow point and one Montell dart point. Finally, Level 4 contained one Scallorn arrow point and two Sabinal arrow points. A charcoal sample taken from Level 5 $(40-50 \mathrm{~cm} \mathrm{bs})$ returned an uncorrected radiocarbon date of $630 \pm 70$ Bp. Notably, only two arrow points and two dart points were recovered below Level 5. In Area B of site 41UV47, a charcoal sample recovered from Level 5 produced an uncorrected radiocarbon date of $800 \pm 110$ BP. A single Ensor dart point was associated with this charcoal sample.

Excavations in Area A of 41UV48 revealed a similarly corroborative date for the arrow points and dart points. A charcoal sample recovered from Level $4(30-40 \mathrm{~cm}$ bs) of XU 91-17 returned an uncorrected radiocarbon date of $740 \pm 70$ вp. Two Edwards arrow points and one Fairland dart point were recovered from this unit level.

The 1967 investigations at the La Jita site (41UV21) examined three burned rock middens with occupations spanning the Archaic through the Late Prehistoric (Hester 1971). Diagnostic stone tools were greatly concentrated in the upper $40 \mathrm{~cm}$ of deposits at the site. Among the 86 projectile points recovered in Levels 1 through 4 in Areas A and C, six Ensor dart points and eight Frio dart points were included. Three separate radiocarbon dates identify Edwards arrow points with Archaic dart points, with dates ranging from roughly 1020 to $910 \mathrm{BP}$. Due to their presence in the Late Prehistoric deposits, Hester (1971:117) suggests these forms to be transitional projectile point types.
An alternate suggestion to the recovery of Archaic dart points in Late Prehistoric contexts is the "recycling" theory. Investigations at the Heard Schoolhouse Site (41UV86) have produced some convincing evidence for Austin interval recycling of Archaic remains (Creel and Goode 1997). A series of 13 radiometric assays from in and around the burned rock midden feature at 41UV86 indicate formation from roughly 1000 through 500 BP. Aside from the eight dart points assigned to the minimal Archaic occupation of the site, 28 dart points were recovered from the Austin interval occupation, including Angostura, Uvalde, Martindale, Nolan, Pedernales, Marshall, Castroville, Marcos, Frio, Ensor, and Fairland types (Creel and Goode 1997:227). They suggest the curation and subsequent reduction strategies in the recycling process an efficient and expedient method of lithic resource procurement (Creel and Goode 1997:229), especially in lithic poor environments.

Following in the recycling vein, in the terrace component of the Mustang Branch site (41HY209-T) in Hays County, one Ensor and one Darl were recovered in context with five Scallorn arrow points (Ricklis and Collins 1994:198). The stratified nature of the deposits and the contemporaneity of the suite of five radiometric dates, which range from roughly 790 to $630 \mathrm{BP}$, led Ricklis and Collins to conclude the dart points curated and recycled, rather than mixing from the isolable, underlying Archaic component.

With these few examples of Transitional Archaic point types in direct association with Late Prehistoric deposits and corroborative radiocarbon dates similar to those of the present study, the depositional integrity of the site as well as the chronology of the site aligns well with the temporal assignment of the Transitional Archaic/Late Prehistoric period for this region of Texas. The lack of temporally diagnostic projectile points of the Late Prehistoric Austin interval (i.e., Edwards arrow points and Scallorn arrow points), suggests that the Transitional Archaic may have predominated at $41 \mathrm{BX} 1421$ as late as roughly $1020 \mathrm{BP}$. In addition, the curation and recycling schema proposed by Ricklis and Collins (1994) and Creel and Goode (1997) is suggested by the extensive reworking of the La Jita dart point (see Figure 14). 
The recovery of the two Leon Plain ceramic sherds in the surface collection is suggestive of an occupation of the Late Prehistoric Toyah interval at 41BX1421. As discussed above, the only likely indicators of a Late Prehistoric component recovered in the mechanical or manual excavations are the two arrow point or arrow point preform fragments. Recovery of both fragments occurred in Test Unit 5 in Level 3 (Catalog No. 38-0091) and Level 4 (Catalog No. 39-011). While the biface fragments are extremely thin and could easily have been translocated downward due to a variety of natural factors, their association with radiocarbon dates between roughly 1020 to $270 \mathrm{BP}$ is consistent with our interpretation of lithic technology for the region. The presence of the ceramic sherds atop ground surface, however, suggest a discrete, shallowly buried Late Prehistoric Toyah component that may have been all but obliterated with recent construction activities.

\section{Faunal Remains}

As Meissner summarizes in Appendix D, nearly 250 vertebrate faunal remains were recovered during the testing phase. With few exceptions, the bones are generally highly fragmented and most display at least some surface pitting consistent with chemical weathering. The faunal assemblage consists entirely of mammalian remains, with only white-tailed deer and blacktailed jackrabbit identifiable on the genus taxonomic level. The remains of a cow- or bison-sized animal with evidence of butchering were recovered in Test Unit 5 in the same level as the two Fairland dart points.

\section{Other Remains}

Other materials and special samples were collected in an attempt to establish the temporal and depositional integrity of 41BX1421. Intrusive historic artifacts such as string, glass, and unidentifiable metal objects were encountered only in Test Unit 2, primarily associated with the colluvial limestone gravels in Zone I (see Figure 5). Additional soil samples were collected from select locations for sediment susceptibility analysis. The results of this analysis are presented in Appendix A.

Terrestrial snail shell was encountered throughout the vertical column of a majority of the test units excavated. Although formal quantitative efforts in the form of a detailed analysis of the land snail samples have not been conducted, it appears that Helicina dominates the overall assemblage. Based upon field observation, Rabdotus occur alongside the Helicina, albeit in fewer numbers. Conversely, relatively sparse amounts of Polygyra were noted during the manual excavations. 


\section{Chapter 6:}

Site 41BX1421 is interpreted as a multicomponent prehistoric open campsite located above and within alluvial deposits atop unconsolidated gravels at the confluence of Medio Creek and an unnamed tributary. The primary feature encountered through mechanical and manual excavations is a sheet midden of burned limestone cobbles that is interpreted as a communal refuse dump spanning the intact remnant of 41BX1421. It is probable that the remainder of the site, that portion containing evidence of occupation features, has been impacted with adjacent and intrusive subdivision development. If this interpretation is correct, then the absence of other features in the extant remnant of the site seems valid.

Based upon two separate vertical columns of radiocarbon assays, it is apparent that the deposits represent a continuous depositional sequence. The artifact assemblage, comprised of materials representative of the Transitional Archaic in South and Central Texas, appear to corroborate the nine radiometric samples. Specifically, with the exception of the Nolan dart point recovered in colluvial deposition away from the midden and probably associated with $41 \mathrm{BX} 466$, the remainder of the temporally diagnostic artifacts was recovered in stratigraphic and chronological order.

It should be noted that Johnson and Goode (1994:38) provide a general range for the bulk of the diagnostic stone tools recovered at 41BX1421 of 2150-1450 BP and Collins (1998:59) similarly provides a general range of 1786-1215 BP for the same materials. The discussion above, however, has presented several instances at various sites where these stone tools have been recovered in much later contexts. One could equally argue contemporaneity or recycling as explanations for the coexistence of these traditionally accepted Late Archaic items encountered in Late Prehistoric sites. Disturbance was not a factor encountered at 41BX1421, and the comparative sites used in the above discussion were chosen for their apparent depositional integrity. The coexistence of Late Archaic II diagnostics and Austin interval diagnostics during the Transitional Archaic of central and southern Texas is a viable interpretation of these data, though recycling of these point types cannot be excluded as an explanation.
In summary, it is the opinion of the author that, prior to the recent construction impacts and archeological testing, 41BX1421 possessed sufficient temporal and depositional integrity to be listed as a State Archeological Landmark (SAL) and to be eligible for inclusion in the National Register of Historic Places (NRHP). However, due to the recent subdivision-related destruction of the approximate northern half and archeological testing in the southern half of the site, the potential to recover additional interpretive data has been exhausted. Further, due to the number of similar sites previously excavated in the region, it is doubtful that additional excavations would provide a substantive contribution to understanding prehistory. It is judged that 41BX1421 is not eligible for listing as a SAL or as a NRHP property. It is therefore recommended that the proposed Loop 1604 improvements proceed without further cultural resources investigations. 


\section{References Cited}

Barnes, V. E.

1976 The Geologic Atlas of Texas, San Antonio Sheet. The University of Texas at Austin.

Black, S.

1989 South Texas Plain. In From the Gulf Coast to the Rio Grande: Human Adaptation in the Central, South, and Lower Pecos Texas, by T. R. Hester, S. L. Black, D. G. Steele, B. W. Olive, A. A. Fox, K. J. Reinhard, and L. C. Bement, pp. 39-62. Research Series No. 33. Arkansas Archeological Survey, Fayetteville.

Black, S. L., and A. J. McGraw

1985 The Panther Springs Creek Site: Cultural Change and Continuity within the Upper Salado Creek Watershed, South-Central Texas. Archaeological Survey Report No. 100. Center for Archaeological Research, The University of Texas at San Antonio.

Blair, W. F.

1950 The Biotic Provinces of Texas. Texas Journal of Science 2(1):93-117.

Bousman, C. B.

1998 Paleoenvironmental Change in Central Texas: The Palynological Evidence. Plains Anthropologist 43(164):201-219.

Collins, M. B.

1995 Forty Years of Archeology in Central Texas. Bulletin of the Texas Archeological Society 66:361-400.

1998 Background to the Archeological Investigations. In Wilson Leonard: An 11,000-year Archeological Record of Hunter-Gatherers in Central Texas, Volume I: Introduction, Background and Syntheses. Assembled and edited by M. B. Collins, pp. 55-68. Studies in Archeology 31, Texas Archeological Research Laboratory, The University of Texas at Austin. Archeology Studies Program, Report 10, Texas Department of Transportation, Environmental Affairs Division, Austin.

Creel, D. G., and G. T. Goode

1997 The Heard Schoolhouse Site, 41UV86. In Hot Rock Cooking on the Edwards Plateau: Four Burned Rock Midden Sites in West Central Texas, edited by S. L. Black, L. W. Ellis, D. G. Creel, and G. T. Goode, pp. 207-234. Studies in Archeology, No. 22. Texas Archeological Research Laboratory, The University of Texas at Austin. Archeology Studies Program, Report No. 2. Texas Department of Transportation, Environmental Affairs Division, Austin.

Creel, D. G., A. J. McGraw, and F. Valdez, Jr.

1979 Excavations at 41LK106, A Prehistoric Occupation Site in Live Oak County, Texas. Archaeological Survey Report, No. 62. Center for Archaeological Research, The University of Texas at San Antonio.

Dillehay, T. D.

1974 Late Quaternary Bison Population Changes on the Southern Plains. Plains Anthropologist 19(65):180-196.

Fenneman, N.

1931 Physiography of the Western United States. McGraw Hill, New York. 
Fields, R. C.

1995 The Archeology of the Post Oak Savannah of East Central Texas. Bulletin of the Texas Archeological Society 66:301-330.

Hall, G. D., S. L. Black, and C. Graves

1982 Archaeological Investigations at the Choke Canyon Reservoir, South Texas: The Phase I Findings. Choke Canyon Series, vol. 5. Center for Archaeological Research, The University of Texas at San Antonio.

Hall, G. D., T. R. Hester, and S. L. Black (editors)

1986 The Prehistoric Sites at Choke Canyon Reservoir, Southern Texas: Results of the Phase II Archaeological Investigations. Choke Canyon Series, vol. 10. Center for Archaeological Research, The University of Texas at San Antonio.

Hester, T. R.

1971 Archeological Investigations at the La Jita Site, Uvalde County, Texas. Bulletin of the Texas Archeological Society 42:51-148.

1978 Background to the Archaeology of Chaparrosa Ranch, Southern Texas. Volume I: Studies in the Archaeology of Chaparrosa Ranch. Special Report No. 6. Center for Archaeological Research, The University of Texas at San Antonio.

1995 The Prehistory of South Texas. Bulletin of the Texas Archeological Society 66:427-459.

Holloway, R. G.

1986 Macrobotanical Analysis of Phase II Materials from the Choke Canyon Reservoir Area, Texas. In Prehistoric Sites at Choke Canyon Reservoir, Southern Texas: Results of Phase II Archaeological Investigations, by G. D. Hall, T. R. Hester, and S. L. Black, pp. 437-451. Choke Canyon Series, vol. 10. Center for Archaeological Research, The University of Texas at San Antonio.

Holmes, A. M.

2000 Archeological Survey with Geoarcheological Evaluation on Loop 1604 at Medio Creek, Bexar County, Texas. Letter Report No. 462. Prewitt and Associates, Inc. Austin.

Houk, B. A., and D. L. Nickels

1997 Phase II Archaeological Investigations at Lackland Air Force Base, San Antonio, Texas. Archaeological Survey Report No. 264. Center for Archaeological Research, The University of Texas at San Antonio.

Johnson, L., Jr.

1995 Past Cultures and Climates at Jonas Terrace 41ME29 Medina County, Texas. Office of the State Archeologist, Report 40. Texas Department of Transportation and Texas Historical Commission, Austin.

Johnson, L., Jr., and G. T. Goode

1994 A New Try at Dating and Characterizing Holocene Climates, as well as Archeological Periods on the Eastern Edwards Plateau. Bulletin of the Texas Archeological Society 65:1-51.

Katz, P. R.

1987 Archaeological Mitigation at 41BX300, Salado Creek Watershed, South-Central Texas. Archaeological Survey Report No. 130. Center for Archaeological Research, The University of Texas at San Antonio. 
Kibler, K. W., and A. M. Scott

2000 Archaic Hunters and Gatherers of the Balcones Canyonlands: Data Recovery at the Cibolo Crossing Site (41BX377), Camp Bullis Military Reservation, Bexar County, Texas. Reports of Investigations Number 126. Prewitt and Associates, Inc., Austin.

Kintigh, K. W.

1992 Tools for Quantitative Archaeology. Tempe, Arizona.

Lukowski, P. D.

1987 Archaeological Investigations along the Leona River Watershed, Uvalde County, Texas. Archaeological Survey Report No. 132. Center for Archaeological Research, The University of Texas at San Antonio.

1988 Archaeological Investigations at 41BX1, Bexar County, Texas. Archaeological Survey Report No. 135. Center for Archaeological Research, The University of Texas at San Antonio.

McGraw, A. J.

1977 A Preliminary Archaeological Survey along the Medio Creek Drainage, Southwestern Bexar County, Texas. Regional Studies No. 3. Center for Archaeological Research, The University of Texas at San Antonio.

McGraw, A. J., J. W. Clark, Jr., and E. A. Robbins (editors)

1998 Part II: Routes Across the Historic Landscape, Spanish Mission Ranchos along the Camino Pita and Camino de en Medio (or Lower Presidio Road). In A Texas Legacy, the Old San Antonio Road and the Caminos Reales: A Tricentennial History, 1691-1991, edited by A. J. McGraw, J. W. Clark, Jr., and E. A. Robbins, pp. 143-152. Texas Department of Transportation, Environmental Affairs Division, Austin.

McGraw, A. J., and K. Hindes

1987 Chipped Stone and Adobe: A Cultural Resources Assessment of the Proposed Applewhite Reservoir, Bexar County, Texas. Archaeological Survey Report No. 163. Center for Archaeological Research, The University of Texas at San Antonio.

Nickels, D. L., C. B. Bousman, J. D. Leach, and D. A. Cargill

2001[1998] Test Excavations at the Culebra Creek Site, 41BX126, Bexar County, Texas. Archaeological Survey Report, No. 265. Center for Archaeological Research, The University of Texas at San Antonio. Archeological Studies Program, Report 3, Texas Department of Transportation, Environmental Affairs Division, Austin.

Nickels, D. L., D. W. Pease, and C. B. Bousman

1997 Archaeological Survey of Lackland Air Force Base, Bexar County, Texas. Archaeological Survey Report No. 248. Center for Archaeological Research, The University of Texas at San Antonio.

Potter, D. R., and S. L. Black

1995 Archeology along the Wurzbach Parkway, Module 2. Initial Testing and Evaluation of Five Prehistoric Sites in the Upper Salado Watershed, Bexar County, Texas. Studies in Archeology, No. 18. Texas Archeological Research Laboratory, The University of Texas at Austin.

Prewitt, E. R.

1981 Cultural Chronology in Central Texas. Bulletin of the Texas Archeological Society 52:65-89.

1985 From Circleville to Toyah: Comments on Central Texas Chronology. Bulletin of the Texas Archeological Society 54:201-238. 
Ramsey, C. B.

2000 OxCal Program Version 3.5. Radiocarbon Accelerator Unit, University of Oxford. Oxford, U.K.

Ricklis, R. A., and M. B. Collins

1994 Archaic and Late Prehistoric Human Ecology in the Middle Onion Creek Valley Hays County, Texas. Volume 1 and 2. Studies in Archeology, No. 19. Texas Archeological Research Laboratory, The University of Texas at Austin.

Steele, D. G., and B. W. Olive

1989 Bioarcheology of Region 3 Study Area. In From the Gulf Coast to the Rio Grande: Human Adaptation in the Central, South, and Lower Pecos Texas, edited by T. R. Hester, S. L. Black, D. G. Steele, B. W. Olive, A. A. Fox, K. J. Reinhard, and L. C. Bement, pp. 93-114. Research Series No. 33. Arkansas Archeological Survey, Fayetteville.

Taylor, A. J., and C. L. Highley

1995 Archaeological Investigations at the Loma Sandia Site (41LK28): A Prehistoric Cemetery and Campsite in Live Oak County, Texas. 2 volumes. Studies in Archeology No. 20. Texas Archeological Research Laboratory, The University of Texas at Austin.

Taylor, F. B., R. B. Hailey, and D. L. Richmond

1991 Soil Survey of Bexar County, Texas. United States Department of Agriculture, Soil Conservation Service. Washington, D.C.

Texas Historical Commission (THC)

2002 Texas Archeological Sites Atlas. <http://www.pedernales.thc.state.tx.us/> Accessed April 2002.

Tomka, S. A., T. K. Perttula, and R. J. Hard

1997 Archaeology of the Rio Grande and Central Coastal Plains, Texas: A Planning Document. Archaeological Survey Report, No. 266. Center for Archaeological Research, The University of Texas at San Antonio.

Vierra, B. J.

1998 41MV120: A Stratified Late Archaic Site in Maverick County, Texas. Archaeological Survey Report, No. 251. Center for Archaeological Research, The University of Texas at San Antonio.

Ward, G. K., and S. R. Wilson

1978 Procedures for Comparing and Combining Radiocarbon Age Determinations: A Critique. Archaeometry 20:19-31.

Wilson, S. R., and G. K. Ward

1981 Evaluation and Clustering of Radiocarbon Age Determinations: Procedures and Paradigms. Archaeometry 21:19-39. 



\title{
Appendix A
}

\section{Magnetic Sediment Susceptibility Testing}

by

\author{
Raymond P. Mauldin
}




\section{Appendix A: $\quad$ Susceptibility Testing}

The magnetic susceptibility (MS) of a given sediment sample can be thought of as a measure of how easily that sample can be magnetized (Dearing 1999; Gose and Nickels 2001[1998]). At low magnetic field strengths, this measure is primarily related to the concentration and grain size of ferro- and ferromagnetic minerals in the sample (Gose and Nickels 2001[1998]). A number of processes can result in an increase in MS values in a sediment sample. Of these processes, those that are of concern here are related to an increase in the organic constitutes or changes in the mineralogy of sediments in a given sample (see Collins et al. 1994; McClean and Kean 1993; Singer and Fine 1989). Sediments with higher organic content tend to have higher magnetic susceptibility values, probably as a result of the production of maghemite, an iron oxide, during organic decay (Reynolds and King 1995). Pedogenic processes, such as soil formation and weathering, can result in the concentration of organic material, as well as alterations in the mineralogy of a given zone. These processes can significantly impact susceptibility readings. Cultural processes, such as the concentration of ash, charcoal, and refuse, would also produce higher MS readings. A measure of the magnetic susceptibility of a sediment sample, then, may provide information on both the presence of surfaces, as well as a measure of the concentration of cultural activity upon those surfaces.

\section{Collection Procedures and Laboratory Methods}

A total of 82 samples was collected for magnetic sediment susceptibility from 41BX1421. Twenty samples were collected from Test Unit 1, 16 samples from Test Unit 3, and 15 samples were collected from Backhoe Trench 2. These samples were collected at 5-cm intervals along a given vertical stretch of a block profile. The remaining 31 samples were collected along Backhoe Trench 2 , at $10-\mathrm{cm}$ intervals, in order to explore the anomaly present in the wall of the trench. In all cases, the samples were placed in plastic bags, and stored in the laboratory at CAR until analysis.

All sediment samples were air dried on a non-metal surface. After drying, the samples were then ground to a uniform grain size using a ceramic mortar and pestle. This method was employed to standardize particle size and make the material easier to handle and pack into sample containers. After each sample was ground, the mortar and pestle were washed with tap water and wiped dry with a paper towel to avoid cross-sample contamination. The ground sample was then poured into a sample container consisting of a plastic cube with external dimensions of $2.54 \times 2.54 \times 1.94 \mathrm{~cm}$. The cubes have an average weight of 4.85 grams. The sediment filled cube was then weighed, and the weight of the sample calculated by subtracting the empty cube weight. This was performed to correct for differences in mass. Assuming that sample volume and material is constant, larger samples should have higher susceptibility values simply as a function of greater mass.

The cube was then placed into a MS2B Dual Frequency Sensor that, in conjunction with a MS2 Magnetic Susceptibility Meter, provided a measure of the magnetic susceptibility of the sample (see Dearing 1999). For each cube, three distinct readings were taken using the SI (standard international) scale. These readings were then averaged to provide a single measure. The value, referred to as volume specific susceptibility and noted with the

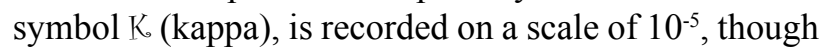
there are no units associated with the value. That is, the value is dimensionless (Dearing 1999).

In order to correct for differences in sample weight, and provide units to the value $K$, the mass specific susceptibility value (X) was calculated using the formula

$$
\mathrm{X}=\left(\mathrm{K}_{\mathrm{o}} / \mathrm{p}\right)
$$

where $\mathrm{p}$ is the sample bulk density expressed in $\mathrm{kg} \mathrm{m}^{-3}$. The bulk density is determined by dividing the sample mass by volume. However, as all samples were measured in identical cubes, and all cubes were full, the sample volume is assumed to be constant. Only the mass of the sample varied. Mass specific susceptibility can be determined by

$$
\mathrm{X}=\mathrm{K} * \text { calibrated mass/ sample mass }
$$


where sample mass is determined by subtracting the cube weight from the total sample weight (Dearing 1999). Calibrated mass is assumed to be 10 grams.

While the resulting values now have both a scale and associated units, the critical element for the current discussion is related to relative differences between $\mathrm{X}$ sample values within a given profile or site, rather than absolute differences. That is, the principal interest is in rapid changes in the mass specific susceptibility values along a profile. This change may signal either a buried surface and/or cultural activity at that location. Comparisons of absolute values between samples from different areas, especially when the parent material of the soils is different, are of limited utility given our current goals.

This can be seen in Table A-1, which lists a variety of examples of mass specific susceptibility values for several different materials. In all cases, the analysis was performed following the procedures outlined previously. Note that the values differ widely, from a low of -1.47 for tap water, to a high of 97.62 for sediments collected from a burned-rock midden. Samples 5 and 6 are of two different clays from the same general setting, far northern Lamar County in north Texas. The mass specific susceptibility is different for these samples, probably as a function of different frequencies of trace elements that, though small in absolute quantity, can dramatically impact the susceptibility values.

The potential impacts of cultural processes on susceptibility values can be seen by considering a data set collected from an archeological site located in Brown County, 41BR473. A total of 279 sediment susceptibility samples was collected from each level of over 50 shovel tests placed at this site. In all cases, the analytical procedures followed those outlined previously. Table A-2 presents summary data on all 279 cases, along with susceptibility scores for those settings that had firecracked rock (FCR) or chipped stone present. If cultural inputs result in higher susceptibility values, then it should be the case that significantly higher susceptibility values will be present in levels that have cultural material.

Table A-1. Magnetic sediment susceptibility data for a variety of substances

\begin{tabular}{|l|c|c|c|c|c|c|c|}
\hline \multicolumn{1}{|c|}{ Sample Type } & $\begin{array}{c}\text { Total } \\
\text { Wt. (gr.) }\end{array}$ & $\begin{array}{c}\text { Sample } \\
\text { Wt. (gr.) }\end{array}$ & $\begin{array}{c}\text { Reading } \\
\mathbf{1}(\mathbf{k})\end{array}$ & $\begin{array}{c}\text { Reading } \\
\mathbf{2}(\mathbf{( k )}\end{array}$ & $\begin{array}{c}\text { Reading } \\
\mathbf{3}(\mathbf{k})\end{array}$ & $\begin{array}{c}\text { Average } \\
\text { K }\end{array}$ & $\begin{array}{c}\text { Corrected } \\
\text { Mass (X) }\end{array}$ \\
\hline $\begin{array}{l}\text { 1) Sandy } \\
\text { sediment with } \\
\text { organics }\end{array}$ & 13.7 & 8.85 & 27.9 & 28 & 28.1 & 28.00 & 31.64 \\
\hline $\begin{array}{l}\text { 2) Modern } \\
\text { mesquite } \\
\text { charcoal and } \\
\text { sediment }\end{array}$ & 9.4 & 4.55 & 10.7 & 10.8 & 10.7 & 10.73 & 23.59 \\
\hline $\begin{array}{l}\text { 3) Modern oak } \\
\text { wood ash }\end{array}$ & 7.5 & 2.65 & 16.1 & 16.2 & 16.2 & 16.17 & 61.01 \\
\hline $\begin{array}{l}\text { 4) Sediment from } \\
\text { burned rock } \\
\text { midden }\end{array}$ & 11.3 & 6.45 & 62.9 & 63 & 63 & 62.97 & 97.62 \\
\hline $\begin{array}{l}\text { 5) Gray clay- } \\
\text { no human } \\
\text { occupation }\end{array}$ & 12.6 & 7.75 & 10.4 & 10.3 & 10.4 & 10.37 & 13.38 \\
\hline $\begin{array}{l}\text { 6) Red clay- } \\
\text { no human } \\
\text { occupation }\end{array}$ & 10.8 & 5.95 & 11.9 & 12 & 12 & 11.97 & 20.11 \\
\hline 7) Sandstone & 14.7 & 9.85 & 6.9 & 7 & 7.1 & 7.00 & 7.11 \\
\hline 8) Limestone & 12.7 & 7.85 & -0.5 & -0.5 & -0.5 & -0.50 & -0.64 \\
\hline 9) Tap water & 10.5 & 5.65 & -0.8 & -0.8 & -0.9 & -0.83 & -1.47 \\
\hline
\end{tabular}


Table A-2. Presence/absence of cultural material and mass specific sediment susceptibility scores for shovel tests at 41BR473

\begin{tabular}{|c|c|c|c|c|c|}
\hline & All Cases & $\begin{array}{c}\text { FCR } \\
\text { Present }\end{array}$ & $\begin{array}{c}\text { FCR } \\
\text { Absent }\end{array}$ & $\begin{array}{c}\text { Chipped Stone } \\
\text { Present }\end{array}$ & $\begin{array}{c}\text { Chipped Stone } \\
\text { Absent }\end{array}$ \\
\hline $\begin{array}{c}\text { Number } \\
\text { of Samples }\end{array}$ & 279 & 84 & 195 & 38 & 241 \\
\hline Mean Value & 48.3 & 56.9 & 44.6 & 55.2 & 47.2 \\
\hline $\begin{array}{c}\text { Standard } \\
\text { Deviation }\end{array}$ & 17.2 & 17.7 & 15.6 & 16.1 & 17.1 \\
\hline
\end{tabular}

An examination of Table A-2 will demonstrate that this is indeed the case. Levels that have FCR present do have higher scores relative to those that lack FCR. Similarly, those levels that have chipped stone present have a higher average mass specific susceptibility score relative to those that lack chipped stone. As the distribution is approximately normal, a t-test was used to test the overall significance of these differences. In both the FCR and chipped stone comparisons, the test confirms that those levels with cultural material have significantly higher scores than those without cultural material (FCR t-statistic $=5.804, \mathrm{df}=277, \mathrm{p}<.001$; chipped stone t-statistic $=2.674, \mathrm{df}=277, \mathrm{p}=.008$ ). Our preliminary investigations, then, coupled with the previous work, clearly suggest that an analysis of the magnetic susceptibility of sediment can provide additional information on both the presence of buried surfaces, as well as the impact of cultural material on those surfaces.

\section{Results}

Table A-3 presents the results of the susceptibility analysis of the 82 samples at 41BX1421. Figures A-1 and A-2 present graphs of the mass specific values for Test Units 1 and 3 (Figure A-1), as well as those associated with the anomaly in BHT 2 (Figure A-2).

Figure A-1, which presents the values for Test Unit 1 (top) and Test Unit 3 (bottom) demonstrate a single, substantial peak at roughly $20 \mathrm{~cm}$ below surface. The two profiles are surprisingly similar suggesting that the processes that are responsible for their formation are similar. The pattern is consistent with a single buried surface at roughly $20 \mathrm{~cm}$ across the area. While there is an additional peak at about $60 \mathrm{~cm}$ below surface in both profiles, the small magnitude of the peak is small and difficult to interpret.

The vertical pattern in Backhoe Trench 2 (see Figure A-2, top) is significantly different from the Test Units 1 and 3 profiles. Samples from this section of the profile were selected in order to explore the potential anomaly present in the trench wall (see Figure 11). The vertical column was collected from the western face of the trench and cut through the anomaly. Note that there are essentially three peaks in the plot, with one at ca. $30 \mathrm{~cm}$ below surface, one at about $47 \mathrm{~cm}$ below surface, and a third at roughly $65 \mathrm{~cm}$ below surface. The initial peak probably corresponds to the initial peaks seen in Test Units 1 and 3. However, the lower peaks clearly reflect a different pattern.

The plot on the bottom in Figure A-2 reflects the results of a series of horizontal samples, collected at $10-\mathrm{cm}$ intervals, taken at $60 \mathrm{~cm}$ below the surface. In conjunction with the vertical data presented in Figure A-2 (top), the values clearly confirm that the anomaly has high values confined to an area roughly $80 \mathrm{~cm}$ northsouth, and roughly $25 \mathrm{~cm}$ in thickness, located $40 \mathrm{~cm}$ below the surface. While a variety of interpretations are possible, the magnetic susceptibility values of these sediments are consistent with the presence of a buried archeological feature. 
Table A-3. Magnetic Susceptibility Values for Test Units 1 and 3, and Backhoe Trench 2

\begin{tabular}{|c|c|c|c|c|c|c|c|c|}
\hline Test Unit & Depth/Location & Weight (g) & Sample Wt. (g) & Reading 1 & Reading 2 & Reading 3 & Average & $\mathbf{X}$ \\
\hline 1 & 5 & 12 & 7.15 & 72.7 & 73.1 & 73.2 & 73.00 & 102.10 \\
\hline 1 & 10 & 12.1 & 7.25 & 82.5 & 82.4 & 82.8 & 82.57 & 113.89 \\
\hline 1 & 15 & 12 & 7.15 & 87.5 & 86.8 & 87.1 & 87.13 & 121.86 \\
\hline 1 & 20 & 12.1 & 7.25 & 91.6 & 92.2 & 91.8 & 91.87 & 126.71 \\
\hline 1 & 25 & 12.2 & 7.35 & 91.2 & 91.1 & 91 & 91.10 & 123.95 \\
\hline 1 & 30 & 12.1 & 7.25 & 86 & 85.6 & 85.8 & 85.80 & 118.34 \\
\hline 1 & 35 & 12 & 7.15 & 82.9 & 82.8 & 82.8 & 82.83 & 115.85 \\
\hline 1 & 40 & 12.2 & 7.35 & 77.9 & 78 & 77.9 & 77.93 & 106.03 \\
\hline 1 & 45 & 12.2 & 7.35 & 72.9 & 73.4 & 73.5 & 73.27 & 99.68 \\
\hline 1 & 50 & 12 & 7.15 & 66.2 & 66.1 & 65.9 & 66.07 & 92.40 \\
\hline 1 & 55 & 12.2 & 7.35 & 65.1 & 64.7 & 65.3 & 65.03 & 88.48 \\
\hline 1 & 60 & 12.2 & 7.35 & 66.7 & 66.2 & 66.2 & 66.37 & 90.29 \\
\hline 1 & 65 & 12.1 & 7.25 & 49 & 49 & 48.9 & 48.97 & 67.54 \\
\hline 1 & 70 & 12 & 7.15 & 39.3 & 39.6 & 40 & 39.63 & 55.43 \\
\hline 1 & 75 & 12.1 & 7.25 & 37.9 & 37.5 & 37.7 & 37.70 & 52.00 \\
\hline 1 & 80 & 12 & 7.15 & 33.1 & 33.4 & 32.9 & 33.13 & 46.34 \\
\hline 1 & 85 & 12 & 7.15 & 32.7 & 32.5 & 32.3 & 32.50 & 45.45 \\
\hline 1 & 90 & 12.2 & 7.35 & 34.1 & 34.3 & 34.3 & 34.23 & 46.58 \\
\hline 1 & 95 & 12 & 7.15 & 31.8 & 31.7 & 32 & 31.83 & 44.52 \\
\hline 1 & 100 & 12.3 & 7.45 & 27.5 & 27.8 & 28.2 & 27.83 & 37.36 \\
\hline 3 & 5 & 12.3 & 7.45 & 66.7 & 66.6 & 66.4 & 66.57 & 89.35 \\
\hline 3 & 10 & 12 & 7.15 & 67.5 & 67.4 & 67 & 67.30 & 94.13 \\
\hline 3 & 15 & 12 & 7.15 & 75.1 & 75.6 & 75.5 & 75.40 & 105.45 \\
\hline 3 & 20 & 12.3 & 7.45 & 81 & 81.5 & 80.5 & 81.00 & 108.72 \\
\hline 3 & 25 & 12.1 & 7.25 & 76.1 & 76.4 & 76.4 & 76.30 & 105.24 \\
\hline 3 & 30 & 12.3 & 7.45 & 78.9 & 78.6 & 78.5 & 78.67 & 105.59 \\
\hline 3 & 35 & 12.1 & 7.25 & 74.4 & 74.2 & 74.2 & 74.27 & 102.44 \\
\hline 3 & 40 & 12.1 & 7.25 & 71.9 & 72 & 71.9 & 71.93 & 99.22 \\
\hline 3 & 45 & 12.3 & 7.45 & 71.5 & 71.4 & 71.5 & 71.47 & 95.93 \\
\hline 3 & 50 & 12 & 7.15 & 65.6 & 66 & 66.2 & 65.93 & 92.21 \\
\hline 3 & 55 & 12.1 & 7.25 & 63 & 62.5 & 63 & 62.83 & 86.67 \\
\hline 3 & 60 & 12 & 7.15 & 62.9 & 62.6 & 63.1 & 62.87 & 87.93 \\
\hline 3 & 65 & 12.2 & 7.35 & 61.3 & 61.2 & 61.2 & 61.23 & 83.31 \\
\hline 3 & 70 & 12.1 & 7.25 & 56 & 55.7 & 55.8 & 55.83 & 77.01 \\
\hline 3 & 75 & 12 & 7.15 & 56.2 & 56 & 55.9 & 56.03 & 78.37 \\
\hline 3 & 80 & 12.1 & 7.25 & 54.8 & 54.8 & 55.2 & 54.93 & 75.77 \\
\hline BHT 2 & 7 & 12.3 & 7.45 & 71.5 & 71.6 & 71.5 & 71.53 & 96.02 \\
\hline BHT 2 & 15 & 12 & 7.15 & 66.9 & 67.1 & 66.8 & 66.93 & 93.61 \\
\hline BHT 2 & 20 & 12 & 7.15 & 65.7 & 65.2 & 65.2 & 65.37 & 91.42 \\
\hline BHT 2 & 25 & 12.1 & 7.25 & 71.4 & 71.5 & 71.6 & 71.50 & 98.62 \\
\hline BHT 2 & 30 & 12.1 & 7.25 & 75.7 & 75.8 & 75.3 & 75.60 & 104.28 \\
\hline BHT 2 & 35 & 12.2 & 7.35 & 68.4 & 68.4 & 68.7 & 68.50 & 93.20 \\
\hline BHT 2 & 40 & 12.1 & 7.25 & 67.3 & 67.2 & 67.4 & 67.30 & 92.83 \\
\hline BHT 2 & 45 & 12.2 & 7.35 & 80 & 80.2 & 80 & 80.07 & 108.93 \\
\hline BHT 2 & 50 & 12.1 & 7.25 & 80.8 & 80.5 & 80.6 & 80.63 & 111.22 \\
\hline BHT 2 & 55 & 12.2 & 7.35 & 79.7 & 79.7 & 79.7 & 79.70 & 108.44 \\
\hline BHT 2 & 60 & 12.2 & 7.35 & 76.7 & 76.3 & 76 & 76.33 & 103.85 \\
\hline BHT 2 & 65 & 12.3 & 7.45 & 82.6 & 82.7 & 82.8 & 82.70 & 111.01 \\
\hline BHT 2 & 70 & 12.1 & 7.25 & 75.8 & 75.3 & 75.8 & 75.63 & 104.32 \\
\hline
\end{tabular}


Table A-3. Continued...

\begin{tabular}{|c|c|c|c|c|c|c|c|c|}
\hline Test Unit & Depth/Location & Weight (g) & Sample Wt. (g) & Reading 1 & Reading 2 & Reading 3 & Average & $\underline{\mathbf{X}}$ \\
\hline BHT 2 & 75 & 12 & 7.15 & 68.3 & 68.6 & 68.4 & 68.43 & 95.71 \\
\hline BHT 2 & 80 & 9.1 & 4.25 & 23.4 & 23.4 & 23.5 & 23.43 & 55.14 \\
\hline BHT 2 at 60 & 0 & 12.2 & 7.35 & 61.8 & 61.5 & 61.3 & 61.53 & 83.72 \\
\hline BHT 2 at 60 & 10 & 12 & 7.15 & 60.3 & 60.3 & 60.8 & 60.47 & 84.57 \\
\hline BHT 2 at 60 & 20 & 12.3 & 7.45 & 60.3 & 60.4 & 60.6 & 60.43 & 81.12 \\
\hline BHT 2 at 60 & 30 & 12.4 & 7.55 & 70.3 & 70 & 69.6 & 69.97 & 92.67 \\
\hline BHT 2 at 60 & 40 & 12.1 & 7.25 & 61.5 & 61.8 & 62 & 61.77 & 85.20 \\
\hline BHT 2 at 60 & 50 & 12.2 & 7.35 & 63 & 63.2 & 62.5 & 62.90 & 85.58 \\
\hline BHT 2 at 60 & 60 & 12 & 7.15 & 64.9 & 64.8 & 64.5 & 64.73 & 90.54 \\
\hline BHT 2 at 60 & 70 & 12.3 & 7.45 & 66.2 & 65.9 & 66.1 & 66.07 & 88.68 \\
\hline BHT 2 at 60 & 80 & 12.3 & 7.45 & 77.3 & 77.3 & 77.4 & 77.33 & 103.80 \\
\hline BHT 2 at 60 & 90 & 12 & 7.15 & 69.9 & 69.8 & 69.9 & 69.87 & 97.72 \\
\hline BHT 2 at 60 & 100 & 12 & 7.15 & 68.6 & 68.4 & 69 & 68.67 & 96.04 \\
\hline BHT 2 at 60 & 110 & 12 & 7.15 & 77.4 & 77.1 & 77.4 & 77.30 & 108.11 \\
\hline BHT 2 at 60 & 120 & 12.1 & 7.25 & 75.5 & 75.3 & 75.1 & 75.30 & 103.86 \\
\hline BHT 2 at 60 & 130 & 12 & 7.15 & 80.3 & 80.2 & 79.8 & 80.10 & 112.03 \\
\hline BHT 2 at 60 & 140 & 12.1 & 7.25 & 84.8 & 84.6 & 84.2 & 84.53 & 116.60 \\
\hline BHT 2 at 60 & 150 & 12.2 & 7.35 & 76.6 & 76.5 & 76.5 & 76.53 & 104.13 \\
\hline BHT 2 at 60 & 160 & 12.4 & 7.55 & 81.8 & 81.6 & 81.5 & 81.63 & 108.12 \\
\hline BHT 2 at 60 & 170 & 12.2 & 7.35 & 80.9 & 80.4 & 80.7 & 80.67 & 109.75 \\
\hline BHT 2 at 60 & 180 & 12.3 & 7.45 & 75 & 75.5 & 75.1 & 75.20 & 100.94 \\
\hline BHT 2 at 60 & 190 & 12.1 & 7.25 & 68.4 & 68.5 & 68.2 & 68.37 & 94.30 \\
\hline BHT 2 at 60 & 200 & 12.1 & 7.25 & 66.7 & 66.9 & 67.1 & 66.90 & 92.28 \\
\hline BHT 2 at 60 & 210 & 12.1 & 7.25 & 67.1 & 67.3 & 67 & 67.13 & 92.60 \\
\hline BHT 2 at 60 & 220 & 12 & 7.15 & 67.3 & 67.7 & 67.4 & 67.47 & 94.36 \\
\hline BHT 2 at 60 & 230 & 12.3 & 7.45 & 76.6 & 77.4 & 76.6 & 76.87 & 103.18 \\
\hline BHT 2 at 60 & 240 & 12.1 & 7.25 & 68.7 & 68.1 & 68.7 & 68.50 & 94.48 \\
\hline BHT 2 at 60 & 250 & 12.1 & 7.25 & 73.7 & 73.9 & 73.3 & 73.63 & 101.56 \\
\hline BHT 2 at 60 & 260 & 12.2 & 7.35 & 74.1 & 74.3 & 73.8 & 74.07 & 100.77 \\
\hline BHT 2 at 60 & 270 & 12.3 & 7.45 & 70.9 & 70.7 & 70.9 & 70.83 & 95.08 \\
\hline BHT 2 at 60 & 280 & 12.2 & 7.35 & 81.3 & 81.2 & 81.8 & 81.43 & 110.79 \\
\hline BHT 2 at 60 & 290 & 12 & 7.15 & 71.1 & 71.9 & 72 & 71.67 & 100.23 \\
\hline BHT 2 at 60 & 300 & 12.2 & 7.35 & 59.5 & 59.1 & 58.8 & 59.13 & 80.45 \\
\hline
\end{tabular}


TU1

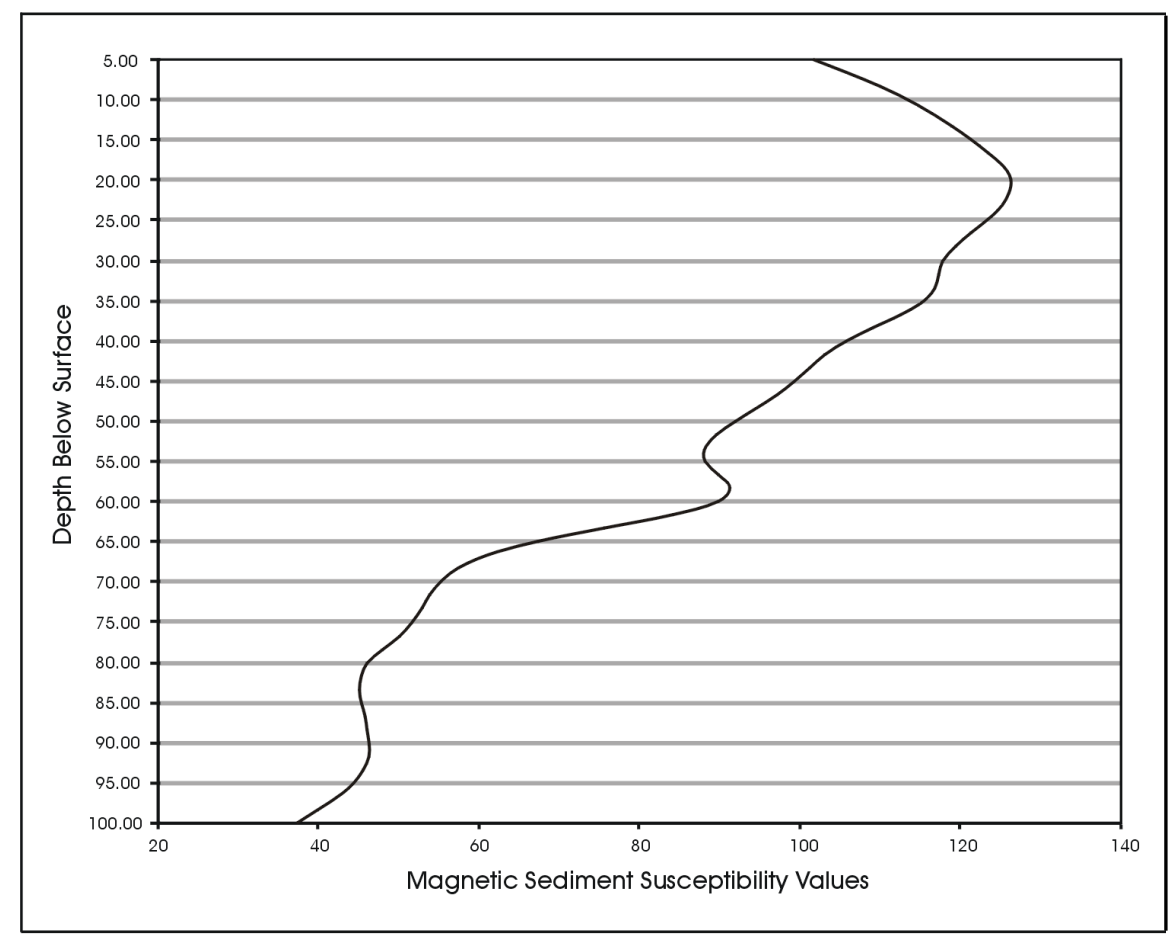

TU3

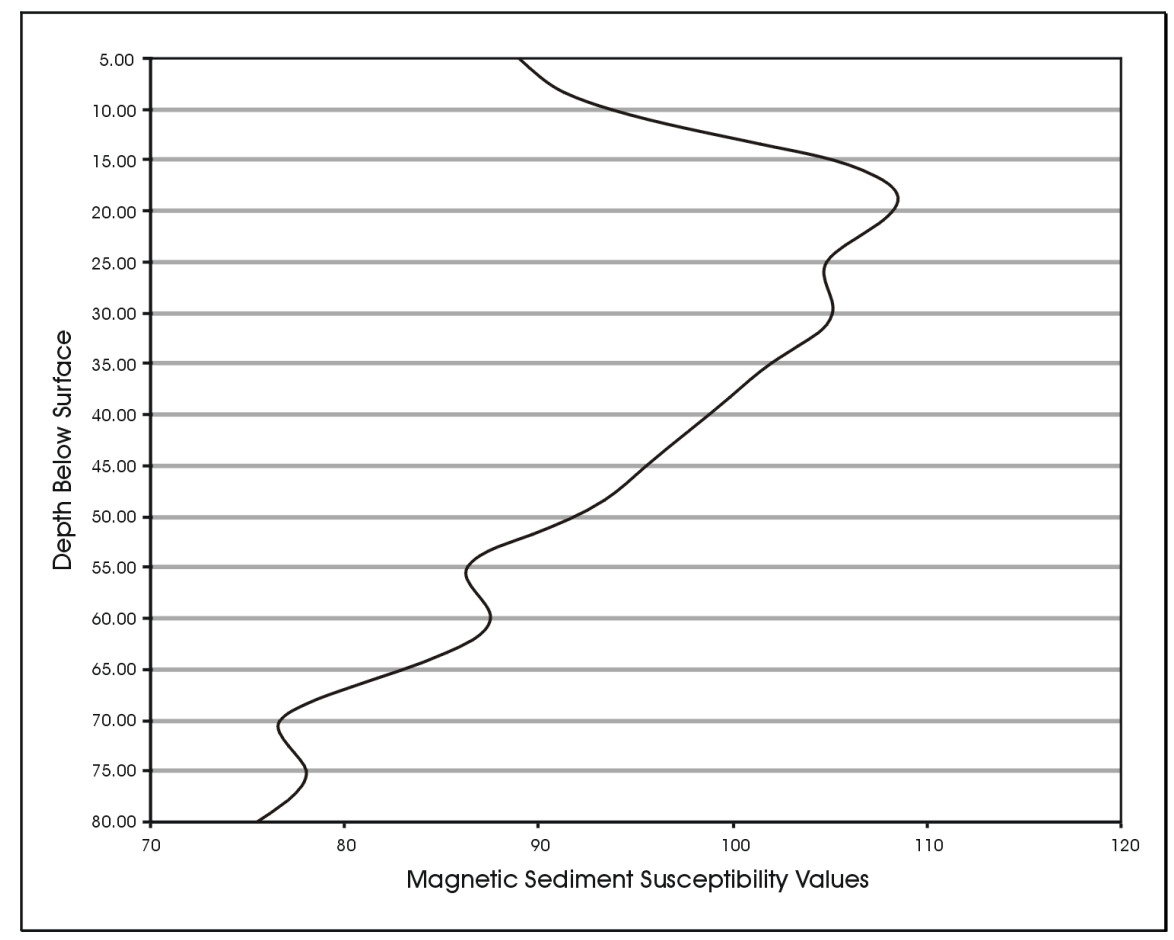

Figure A-1. Mass specific values graphs for Test Units 1 and 3. 
BHT 2

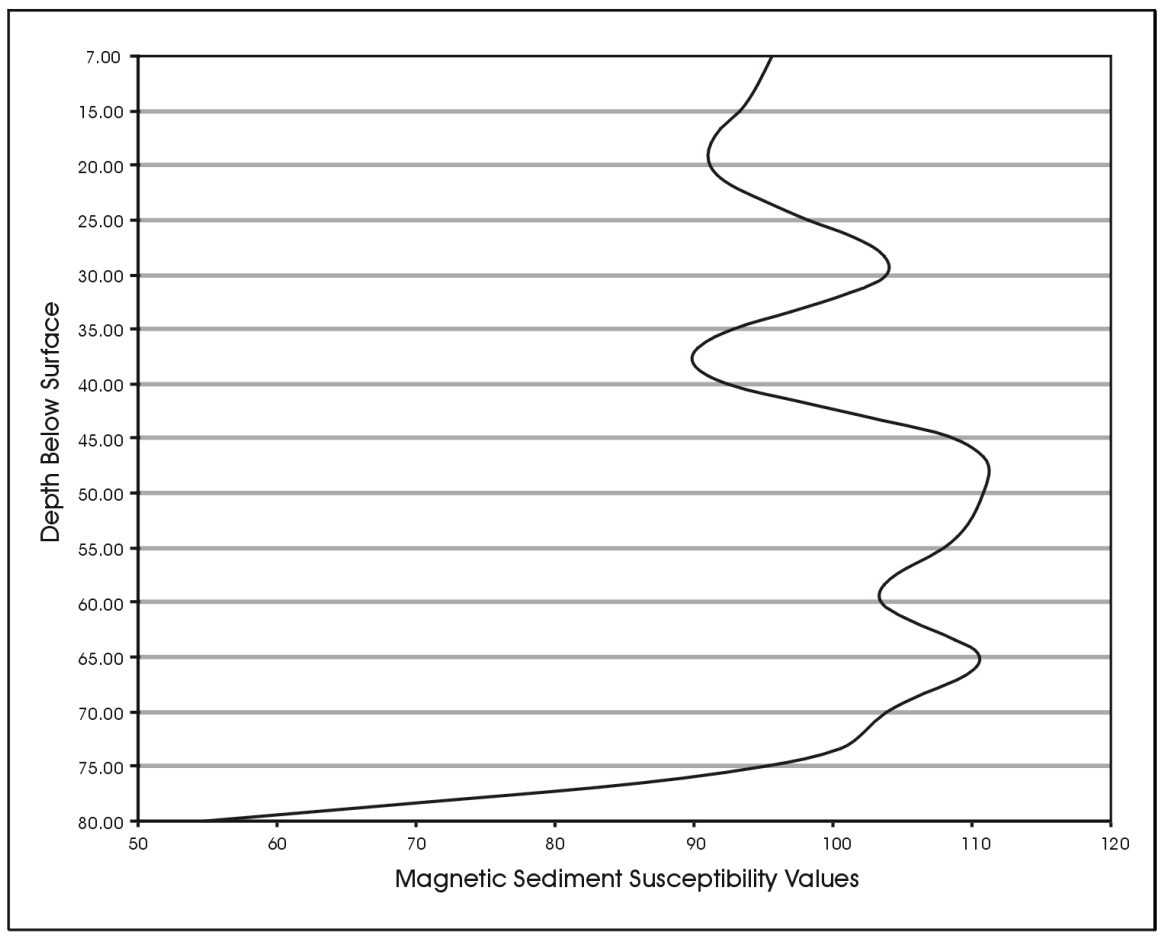

BHT 2

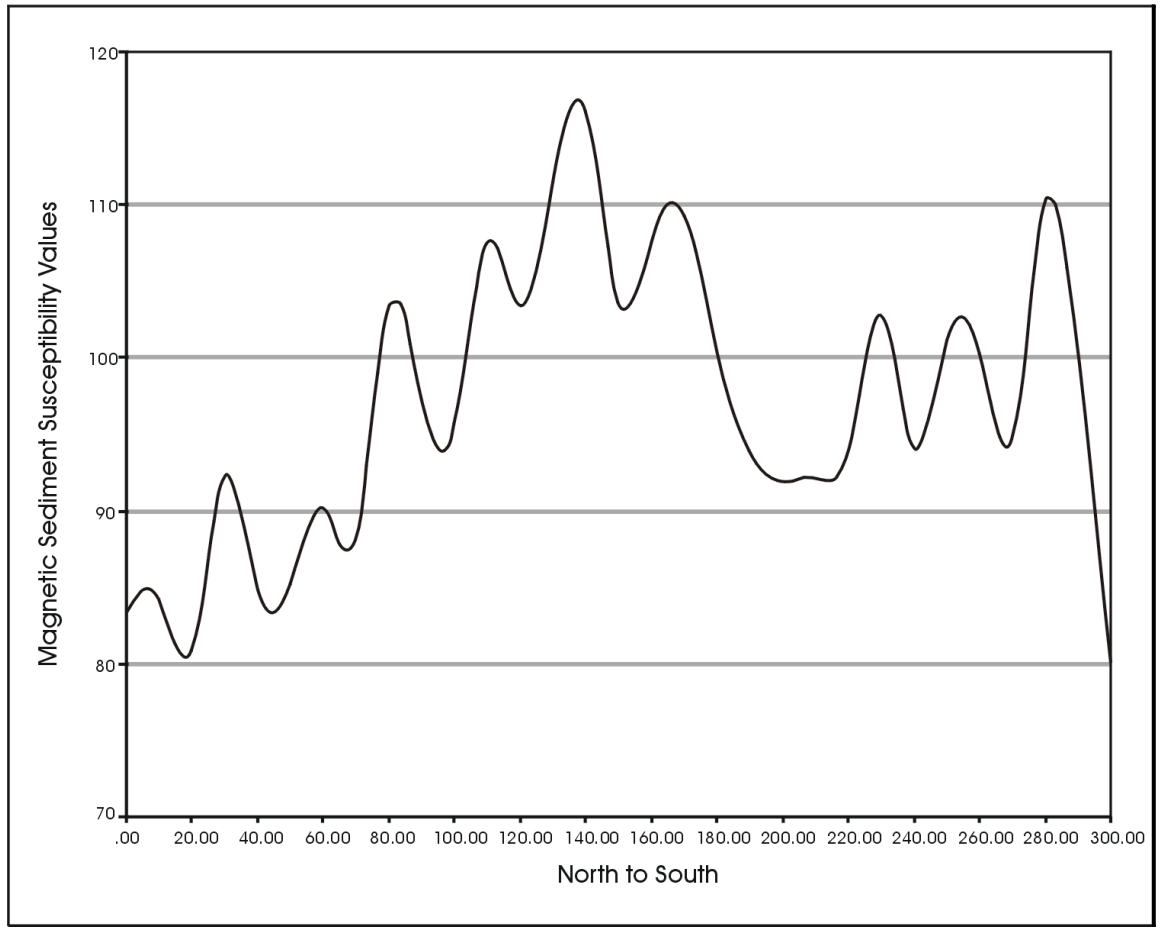

Figure A-2. Mass specific values graphs for Backhoe Trench 2. 


\section{References Cited}

Collins, M. B., W. A. Gose, and S. Shaw

1994 Preliminary Geomorphological Findings at Dust and Nearby Caves. Journal of Alabama Archaeology 40:35-56.

Dearing, J.

1999 Environmental Magnetic Susceptibility. Chi publishing, Kenilworth, England.

Gose, W. A., and D. L. Nickels

2001[1998] Archaeomagnetic and Magnetic Susceptibility Analyses. In Test Excavations at the Culebra Creek Site, 41BX126, Bexar County, Texas, by D. L. Nickels, C. B. Bousman, J. D. Leach, and D. A. Cargill, pp. 204-214. Archaeological Survey Report, No. 265, Center for Archaeological Research, The University of Texas at San Antonio; Archeology Studies Program, Report 3, Environmental Affairs Division, Texas Department of Transportation, Austin.

McClean, R. G., and W. F. Kean

1993 Contributions of Wood Ash Magnetism to Archeomagnetic Properties of Fire Pits and Hearths. Earth and Planetary Science Letters 119:387-394.

Reynolds, R. L., and J. W. King

1995 Magnetic Records of Climate Change. U.S. National Report to I.U.G.G., 1991-1994. American Geophysical Union. <http://www.agu.ong/revgeophys/reyno100/reyno100.html> Accessed April 2001.

Singer, M. J., and P. Fine

1989 Pedogenic Factors Affecting Magnetic Susceptibility of Northern California Soils. Soil Science Society of America Journal 53:1119-1127. 



\section{Appendix B}

\section{Artifact and Ecofact Recovery by Unit and Level}


Table B-1. Artifacts and ecofacts recovered from 41BX1421

\begin{tabular}{|c|c|c|c|c|c|c|c|}
\hline Lot No. & Unit & Level & Depth & Catalog No. & Class & Count & Weight (g) \\
\hline 5 & Test Unit 1 & 1 & $0-10 \mathrm{~cm}$ & $5-001$ & Snail Shell & 1 & 0000.00 \\
\hline 5 & Test Unit 1 & 1 & $0-10 \mathrm{~cm}$ & $5-002$ & Lithics & 17 & 0000.00 \\
\hline 5 & Test Unit 1 & 1 & $0-10 \mathrm{~cm}$ & $5-003$ & Bone & 2 & 0000.00 \\
\hline 5 & Test Unit 1 & 1 & $0-10 \mathrm{~cm}$ & 5-004 & Burned Rock & 108 & 2198.30 \\
\hline 6 & Test Unit 1 & 2 & $10-20 \mathrm{~cm}$ & 6-001 & Lithics & 210 & 0000.00 \\
\hline 6 & Test Unit 1 & 2 & $10-20 \mathrm{~cm}$ & 6-002 & Burned Rock & 91 & 0057.40 \\
\hline 6 & Test Unit 1 & 2 & $10-20 \mathrm{~cm}$ & 6-003 & Snail Shell & 1 & 0000.00 \\
\hline 6 & Test Unit 1 & 2 & $10-20 \mathrm{~cm}$ & 6-004 & Bone & 17 & 0000.00 \\
\hline 6 & Test Unit 1 & 2 & $10-20 \mathrm{~cm}$ & 6-005 & Soil Sample/Flotation & 1 & 0000.00 \\
\hline 6 & Test Unit 1 & 2 & $10-20 \mathrm{~cm}$ & $6-006$ & Charcoal & 1 & 0000.00 \\
\hline 7 & Test Unit 1 & 3 & $20-30 \mathrm{~cm}$ & 7-001 & Soil Sample/Flotation & 1 & 0000.00 \\
\hline 7 & Test Unit 1 & 3 & $20-30 \mathrm{~cm}$ & 7-002 & Lithics & 82 & 0000.00 \\
\hline 7 & Test Unit 1 & 3 & $20-30 \mathrm{~cm}$ & $7-003$ & Snail Shell & 1 & 0000.00 \\
\hline 7 & Test Unit 1 & 3 & $20-30 \mathrm{~cm}$ & $7-004$ & Bone & 11 & 0000.00 \\
\hline 7 & Test Unit 1 & 3 & $20-30 \mathrm{~cm}$ & $7-005$ & Mussel Shell & 1 & 0000.00 \\
\hline 7 & Test Unit 1 & 3 & $20-30 \mathrm{~cm}$ & $7-006$ & Charcoal & 1 & 0000.00 \\
\hline 7 & Test Unit 1 & 3 & $20-30 \mathrm{~cm}$ & $7-007$ & Point & 1 & 0000.00 \\
\hline 7 & Test Unit 1 & 3 & $20-30 \mathrm{~cm}$ & $7-009$ & Other & 1 & 0000.00 \\
\hline 7 & Test Unit 1 & 3 & $20-30 \mathrm{~cm}$ & 7-010-01 & Burned Rock & 121 & 9750.40 \\
\hline 7 & Test Unit 1 & 3 & $20-30 \mathrm{~cm}$ & $7-010-02$ & Burned Rock & 120 & 0000.00 \\
\hline 8 & Test Unit 1 & 4 & $30-40 \mathrm{~cm}$ & 8-001 & Soil Sample/Flotation & 1 & 0000.00 \\
\hline 8 & Test Unit 1 & 4 & $30-40 \mathrm{~cm}$ & 8-002 & Charcoal & 1 & 0000.00 \\
\hline 8 & Test Unit 1 & 4 & $30-40 \mathrm{~cm}$ & $8-003$ & Lithics & 579 & 0000.00 \\
\hline 8 & Test Unit 1 & 4 & $30-40 \mathrm{~cm}$ & 8-004 & Snail Shell & 1 & 0000.00 \\
\hline 8 & Test Unit 1 & 4 & $30-40 \mathrm{~cm}$ & 8-005 & Mussel Shell & 1 & 0000.00 \\
\hline 8 & Test Unit 1 & 4 & $30-40 \mathrm{~cm}$ & 8-006-01 & Burned Rock & 85 & 2462.10 \\
\hline 8 & Test Unit 1 & 4 & $30-40 \mathrm{~cm}$ & 8-006-02 & Burned Rock & 164 & 4889.50 \\
\hline 8 & Test Unit 1 & 4 & $30-40 \mathrm{~cm}$ & 8-006-03 & Burned Rock & 104 & 4082.30 \\
\hline 8 & Test Unit 1 & 4 & $30-40 \mathrm{~cm}$ & 8-007 & Point & 1 & 0000.00 \\
\hline 8 & Test Unit 1 & 4 & $30-40 \mathrm{~cm}$ & 8-008 & Bone & 12 & 0000.00 \\
\hline 8 & Test Unit 1 & 4 & $30-40 \mathrm{~cm}$ & 8-008-02 & Bone & 58 & 0000.00 \\
\hline 8 & Test Unit 1 & 4 & $30-40 \mathrm{~cm}$ & 8-009 & Point & 1 & 0000.00 \\
\hline 8 & Test Unit 1 & 4 & $30-40 \mathrm{~cm}$ & $8-010$ & Charcoal & 1 & 0000.00 \\
\hline 9 & Test Unit 1 & 5 & $40-50 \mathrm{~cm}$ & 9-001 & Lithics & 129 & 0000.00 \\
\hline 9 & Test Unit 1 & 5 & $40-50 \mathrm{~cm}$ & 9-002 & Snail Shell & 1 & 0000.00 \\
\hline 9 & Test Unit 1 & 5 & $40-50 \mathrm{~cm}$ & 9-003-01 & Burned Rock & 113 & 2721.60 \\
\hline 9 & Test Unit 1 & 5 & $40-50 \mathrm{~cm}$ & 9-003-02 & Burned Rock & 94 & 7257.50 \\
\hline 9 & Test Unit 1 & 5 & $40-50 \mathrm{~cm}$ & 9-004 & Soil Sample/Flotation & 1 & 0000.00 \\
\hline 9 & Test Unit 1 & 5 & $40-50 \mathrm{~cm}$ & 9-005 & Charcoal & 1 & 0000.00 \\
\hline 9 & Test Unit 1 & 5 & $40-50 \mathrm{~cm}$ & 9-006 & Lithics & 5 & 0000.00 \\
\hline 9 & Test Unit 1 & 5 & $40-50 \mathrm{~cm}$ & $9-007$ & Other & 1 & 0000.00 \\
\hline 9 & Test Unit 1 & 5 & $40-50 \mathrm{~cm}$ & $9-008$ & Charcoal & 1 & 0000.00 \\
\hline 9 & Test Unit 1 & 5 & $40-50 \mathrm{~cm}$ & 9-009 & Charcoal & 1 & 0000.00 \\
\hline 9 & Test Unit 1 & 5 & $40-50 \mathrm{~cm}$ & 9-010 & Charcoal & 1 & 0000.00 \\
\hline 9 & Test Unit 1 & 5 & $40-50 \mathrm{~cm}$ & 9-011 & Charcoal & 1 & 0000.00 \\
\hline 9 & Test Unit 1 & 5 & $40-50 \mathrm{~cm}$ & 9-012 & Bone & 32 & 0000.00 \\
\hline 10 & Test Unit 1 & 6 & $50-60 \mathrm{~cm}$ & $10-001$ & Soil Sample/Flotation & 1 & 0000.00 \\
\hline 10 & Test Unit 1 & 6 & $50-60 \mathrm{~cm}$ & $10-002$ & Soil Sample/Flotation & 1 & 0000.00 \\
\hline 11 & Test Unit 1 & 6 & $50-60 \mathrm{~cm}$ & $11-001$ & Lithics & 52 & 0000.00 \\
\hline 11 & Test Unit 1 & 6 & $50-60 \mathrm{~cm}$ & $11-002$ & Charcoal & 1 & 0000.00 \\
\hline 11 & Test Unit 1 & 6 & $50-60 \mathrm{~cm}$ & $11-003-01$ & Burned Rock & 15 & 0715.30 \\
\hline 11 & Test Unit 1 & 6 & $50-60 \mathrm{~cm}$ & $11-003-02$ & Burned Rock & 116 & 12927.40 \\
\hline 11 & Test Unit 1 & 6 & $50-60 \mathrm{~cm}$ & $11-003-03$ & Burned Rock & 30 & 11113.00 \\
\hline 11 & Test Unit 1 & 6 & $50-60 \mathrm{~cm}$ & $11-004$ & Snail Shell & 1 & 0000.00 \\
\hline 11 & Test Unit 1 & 6 & $50-60 \mathrm{~cm}$ & $11-006$ & Charcoal & 1 & 0000.00 \\
\hline 12 & Test Unit 1 & 7 & $60-70 \mathrm{~cm}$ & $12-001$ & Soil Sample/Flotation & 1 & 0000.00 \\
\hline 12 & Test Unit 1 & 7 & $60-70 \mathrm{~cm}$ & $12-003$ & Snail Shell & 1 & 0000.00 \\
\hline 12 & Test Unit 1 & 7 & $60-70 \mathrm{~cm}$ & $12-004$ & Charcoal & 1 & 0000.00 \\
\hline 12 & Test Unit 1 & 7 & $60-70 \mathrm{~cm}$ & $12-005$ & Burned Rock & 72 & 1842.40 \\
\hline 12 & Test Unit 1 & 7 & $60-70 \mathrm{~cm}$ & $12-006$ & Lithics & 17 & 0000.00 \\
\hline 12 & Test Unit 1 & 7 & $60-70 \mathrm{~cm}$ & $12-007$ & Bone & 3 & 0000.00 \\
\hline
\end{tabular}


Table B-1. Continued...

\begin{tabular}{|c|c|c|c|c|c|c|c|}
\hline Lot No. & Unit & Level & Depth & Catalog No. & Class & Count & Weight (g) \\
\hline 13 & Test Unit 1 & 9 & $80-90 \mathrm{~cm}$ & 13-001 & Soil Sample/Flotation & 1 & 0000.00 \\
\hline 13 & Test Unit 1 & 9 & $80-90 \mathrm{~cm}$ & $13-002$ & Snail Shell & 1 & 0000.00 \\
\hline 13 & Test Unit 1 & 9 & $80-90 \mathrm{~cm}$ & $13-004$ & Tool & 1 & 0000.00 \\
\hline 13 & Test Unit 1 & 9 & $80-90 \mathrm{~cm}$ & $13-005$ & Burned Rock & 3 & 0024.00 \\
\hline 13 & Test Unit 1 & 9 & $80-90 \mathrm{~cm}$ & $13-006$ & Lithics & 6 & 0000.00 \\
\hline 13 & Test Unit 1 & 9 & $80-90 \mathrm{~cm}$ & $13-007$ & Burned Rock & 2 & 0082.40 \\
\hline 13 & Test Unit 1 & 9 & $80-90 \mathrm{~cm}$ & $13-008$ & Snail Shell & 1 & 0000.00 \\
\hline 14 & Test Unit 1 & 10 & $90-100 \mathrm{~cm}$ & $14-001$ & Soil Sample/Flotation & 1 & 0000.00 \\
\hline 15 & Test Unit 2 & 1 & $0-20 \mathrm{~cm}$ & $15-001$ & Burned Rock & 21 & 0072.90 \\
\hline 15 & Test Unit 2 & 1 & $0-20 \mathrm{~cm}$ & $15-002$ & Snail Shell & 1 & 0000.00 \\
\hline 15 & Test Unit 2 & 1 & $0-20 \mathrm{~cm}$ & $15-003$ & Lithics & 1 & 0000.00 \\
\hline 16 & Test Unit 2 & 2 & $20-30 \mathrm{~cm}$ & $16-001$ & Soil Sample/Flotation & 1 & 0000.00 \\
\hline 16 & Test Unit 2 & 2 & $20-30 \mathrm{~cm}$ & $16-002$ & Snail Shell & 1 & 0000.00 \\
\hline 16 & Test Unit 2 & 2 & $20-30 \mathrm{~cm}$ & $16-003$ & Lithics & 2 & 0000.00 \\
\hline 16 & Test Unit 2 & 2 & $20-30 \mathrm{~cm}$ & $16-004$ & Historic & 2 & 0000.00 \\
\hline 16 & Test Unit 2 & 2 & $20-30 \mathrm{~cm}$ & $16-005$ & Burned Rock & 119 & 0510.30 \\
\hline 17 & Test Unit 2 & 3 & $30-40 \mathrm{~cm}$ & $17-001$ & Snail Shell & 1 & 0000.00 \\
\hline 17 & Test Unit 2 & 3 & $30-40 \mathrm{~cm}$ & $17-002$ & Burned Rock & 56 & 0212.20 \\
\hline 17 & Test Unit 2 & 3 & $30-40 \mathrm{~cm}$ & $17-004$ & Bone & 1 & 0000.00 \\
\hline 17 & Test Unit 2 & 3 & $30-40 \mathrm{~cm}$ & $17-005$ & Point & 1 & 0000.00 \\
\hline 17 & Test Unit 2 & 3 & $30-40 \mathrm{~cm}$ & $17-006$ & Soil Sample/Flotation & 1 & 0000.00 \\
\hline 17 & Test Unit 2 & 3 & $30-40 \mathrm{~cm}$ & $17-007$ & Lithics & 3 & 0000.00 \\
\hline 18 & Test Unit 2 & 4 & $40-50 \mathrm{~cm}$ & $18-001$ & Snail Shell & 1 & 0000.00 \\
\hline 18 & Test Unit 2 & 4 & $40-50 \mathrm{~cm}$ & $18-002$ & Historic & 2 & 0000.00 \\
\hline 18 & Test Unit 2 & 4 & $40-50 \mathrm{~cm}$ & $18-003$ & Burned Rock & 58 & 0203.50 \\
\hline 18 & Test Unit 2 & 4 & $40-50 \mathrm{~cm}$ & $18-004$ & Soil Sample/Flotation & 1 & 0000.00 \\
\hline 19 & Test Unit 2 & 5 & $50-60 \mathrm{~cm}$ & $19-001$ & Burned Rock & 53 & 0258.00 \\
\hline 19 & Test Unit 2 & 5 & $50-60 \mathrm{~cm}$ & $19-002$ & Lithics & 4 & 0000.00 \\
\hline 19 & Test Unit 2 & 5 & $50-60 \mathrm{~cm}$ & $19-003$ & Snail Shell & 1 & 0000.00 \\
\hline 19 & Test Unit 2 & 5 & $50-60 \mathrm{~cm}$ & 19-004 & Soil Sample/Flotation & 1 & 0000.00 \\
\hline 20 & Test Unit 2 & 6 & $60-70 \mathrm{~cm}$ & $20-001$ & Burned Rock & 11 & 0057.60 \\
\hline 20 & Test Unit 2 & 6 & $60-70 \mathrm{~cm}$ & $20-002$ & Charcoal & 1 & 0000.00 \\
\hline 20 & Test Unit 2 & 6 & $60-70 \mathrm{~cm}$ & $20-004$ & Soil Sample/Flotation & 1 & 0000.00 \\
\hline 21 & Test Unit 2 & 7 & $70-80 \mathrm{~cm}$ & 21-001 & Soil Sample/Flotation & 1 & 0000.00 \\
\hline 21 & Test Unit 2 & 7 & $70-80 \mathrm{~cm}$ & 21-002 & Snail Shell & 1 & 0000.00 \\
\hline 22 & Test Unit 3 & 1 & $0-10 \mathrm{~cm}$ & 22-001 & Lithics & 8 & 0000.00 \\
\hline 22 & Test Unit 3 & 1 & $0-10 \mathrm{~cm}$ & $22-002$ & Snail Shell & 1 & 0000.00 \\
\hline 22 & Test Unit 3 & 1 & $0-10 \mathrm{~cm}$ & $22-003$ & Bone & 1 & 0000.00 \\
\hline 22 & Test Unit 3 & 1 & $0-10 \mathrm{~cm}$ & 22-004 & Mussel Shell & 1 & 0000.00 \\
\hline 22 & Test Unit 3 & 1 & $0-10 \mathrm{~cm}$ & $22-005$ & Burned Rock & 25 & 1010.50 \\
\hline 22 & Test Unit 3 & 1 & $0-10 \mathrm{~cm}$ & $22-006$ & Soil Sample/Flotation & 1 & 0000.00 \\
\hline 23 & Test Unit 3 & 2 & $10-20 \mathrm{~cm}$ & $23-002$ & Burned Rock & 51 & 2360.40 \\
\hline 23 & Test Unit 3 & 2 & $10-20 \mathrm{~cm}$ & 23-002-02 & Lithics & 29 & 0000.00 \\
\hline 23 & Test Unit 3 & 2 & $10-20 \mathrm{~cm}$ & 23-003 & Soil Sample/Flotation & 1 & 0000.00 \\
\hline 23 & Test Unit 3 & 2 & $10-20 \mathrm{~cm}$ & 23-004 & Soil Sample/Flotation & 1 & 0000.00 \\
\hline 23 & Test Unit 3 & 2 & $10-20 \mathrm{~cm}$ & 23-005 & Snail Shell & 1 & 0000.00 \\
\hline 23 & Test Unit 3 & 2 & $10-20 \mathrm{~cm}$ & $23-006$ & Lithics & 8 & 0000.00 \\
\hline 23 & Test Unit 3 & 2 & $10-20 \mathrm{~cm}$ & 23-007 & Burned Rock & 56 & 2913.20 \\
\hline 23 & Test Unit 3 & 2 & $10-20 \mathrm{~cm}$ & $23-008$ & Snail Shell & 1 & 0000.00 \\
\hline 24 & Test Unit 3 & 2 & $15 \mathrm{~cm}$ & 24-001 & Charcoal & 1 & 0000.00 \\
\hline 25 & Test Unit 3 & 2 & $19 \mathrm{~cm}$ & 25-001 & Charcoal & 1 & 0000.00 \\
\hline 26 & Test Unit 3 & 3 & $20-30 \mathrm{~cm}$ & 26-001 & Burned Rock & 61 & 2478.00 \\
\hline 26 & Test Unit 3 & 3 & $20-30 \mathrm{~cm}$ & $26-002$ & Mussel Shell & 1 & 0000.00 \\
\hline 26 & Test Unit 3 & 3 & $20-30 \mathrm{~cm}$ & $26-003$ & Lithics & 23 & 0000.00 \\
\hline 26 & Test Unit 3 & 3 & $20-30 \mathrm{~cm}$ & 26-004 & Snail Shell & 1 & 0000.00 \\
\hline 26 & Test Unit 3 & 3 & $20-30 \mathrm{~cm}$ & $26-005$ & Soil Sample/Flotation & 1 & 0000.00 \\
\hline 27 & Test Unit 3 & 4 & $30-40 \mathrm{~cm}$ & $27-001$ & Soil Sample/Flotation & 1 & 0000.00 \\
\hline 27 & Test Unit 3 & 4 & $30-40 \mathrm{~cm}$ & 27-002-01 & Burned Rock & 12 & 0027.40 \\
\hline 27 & Test Unit 3 & 4 & $30-40 \mathrm{~cm}$ & $27-002-02$ & Burned Rock & 103 & 5896.70 \\
\hline 27 & Test Unit 3 & 4 & $30-40 \mathrm{~cm}$ & $27-003$ & Snail Shell & 1 & 0000.00 \\
\hline 27 & Test Unit 3 & 4 & $30-40 \mathrm{~cm}$ & 27-004 & Lithics & 59 & 0000.00 \\
\hline
\end{tabular}


Table B-1. Continued...

\begin{tabular}{|c|c|c|c|c|c|c|c|}
\hline Lot No. & Unit & Level & Depth & Catalog No. & Class & Count & Weight (g) \\
\hline 27 & Test Unit 3 & 4 & $30-40 \mathrm{~cm}$ & $27-005$ & Bone & 10 & 0000.00 \\
\hline 27 & Test Unit 3 & 4 & $30-40 \mathrm{~cm}$ & $27-006$ & Charcoal & 1 & 0000.00 \\
\hline 27 & Test Unit 3 & 4 & $30-40 \mathrm{~cm}$ & $27-007$ & Charcoal & 1 & 0000.00 \\
\hline 28 & Test Unit 3 & 5 & $40-50 \mathrm{~cm}$ & 28-001-01 & Burned Rock & 5 & 0000.00 \\
\hline 28 & Test Unit 3 & 5 & $40-50 \mathrm{~cm}$ & 28-001-02 & Burned Rock & 117 & 12020.20 \\
\hline 28 & Test Unit 3 & 5 & $40-50 \mathrm{~cm}$ & $28-002$ & Lithics & 11 & 0000.00 \\
\hline 28 & Test Unit 3 & 5 & $40-50 \mathrm{~cm}$ & $28-003$ & Snail Shell & 1. & 0000.00 \\
\hline 28 & Test Unit 3 & 5 & $40-50 \mathrm{~cm}$ & 28-004 & Bone & 15 & 0000.00 \\
\hline 28 & Test Unit 3 & 5 & $40-50 \mathrm{~cm}$ & $28-005$ & Soil Sample/Flotation & 1 & 0000.00 \\
\hline 28 & Test Unit 3 & 5 & $40-50 \mathrm{~cm}$ & $28-006$ & Charcoal & 1 & 0000.00 \\
\hline 28 & Test Unit 3 & 5 & $40-50 \mathrm{~cm}$ & $28-007$ & Mussel Shell & 1 & 0000.00 \\
\hline 29 & Test Unit 3 & 6 & $50-60 \mathrm{~cm}$ & 29-001 & Lithics & 4 & 0000.00 \\
\hline 29 & Test Unit 3 & 6 & $50-60 \mathrm{~cm}$ & 29-002 & Snail Shell & 1 & 0000.00 \\
\hline 29 & Test Unit 3 & 6 & $50-60 \mathrm{~cm}$ & $29-003$ & Soil Sample/Flotation & 1 & 0000.00 \\
\hline 29 & Test Unit 3 & 6 & $50-60 \mathrm{~cm}$ & 29-004-01 & Burned Rock & 5 & 4309.10 \\
\hline 29 & Test Unit 3 & 6 & $50-60 \mathrm{~cm}$ & 29-004-02 & Burned Rock & 38 & 4535.90 \\
\hline 29 & Test Unit 3 & 6 & $50-60 \mathrm{~cm}$ & $29-004-03$ & Burned Rock & 14 & 5669.90 \\
\hline 29 & Test Unit 3 & 6 & $50-60 \mathrm{~cm}$ & 29-004-04 & Burned Rock & 8 & 6123.50 \\
\hline 29 & Test Unit 3 & 6 & $50-60 \mathrm{~cm}$ & 29-004-05 & Burned Rock & 26 & 11793.40 \\
\hline 29 & Test Unit 3 & 6 & $50-60 \mathrm{~cm}$ & 29-004-06 & Burned Rock & 50 & 2168.40 \\
\hline 29 & Test Unit 3 & 6 & $50-60 \mathrm{~cm}$ & 29-004-07 & Burned Rock & 8 & 11566.60 \\
\hline 29 & Test Unit 3 & 6 & $50-60 \mathrm{~cm}$ & 29-004-08 & Burned Rock & 8 & 4535.90 \\
\hline 29 & Test Unit 3 & 6 & $50-60 \mathrm{~cm}$ & $29-005$ & Bone & 13 & 0000.00 \\
\hline 30 & Test Unit 3 & 7 & $60-70 \mathrm{~cm}$ & $30-001$ & Soil Sample/Flotation & 1 & 0000.00 \\
\hline 30 & Test Unit 3 & 7 & $60-70 \mathrm{~cm}$ & $30-002$ & Snail Shell & 1 & 0000.00 \\
\hline 30 & Test Unit 3 & 7 & $60-70 \mathrm{~cm}$ & $30-003$ & Lithics & 19 & 0000.00 \\
\hline 30 & Test Unit 3 & 7 & $60-70 \mathrm{~cm}$ & 30-004 & Burned Rock & 139 & 13108.80 \\
\hline 31 & Test Unit 3 & 8 & $70-80 \mathrm{~cm}$ & $31-001$ & Soil Sample/Flotation & 1 & 0000.00 \\
\hline 31 & Test Unit 3 & 8 & $70-80 \mathrm{~cm}$ & $31-002$ & Snail Shell & 1 & 0000.00 \\
\hline 31 & Test Unit 3 & 8 & $70-80 \mathrm{~cm}$ & $31-003$ & Lithics & 1 & 0000.00 \\
\hline 31 & Test Unit 3 & 8 & $70-80 \mathrm{~cm}$ & $31-004-01$ & Burned Rock & 122 & 12247.00 \\
\hline 31 & Test Unit 3 & 8 & $70-80 \mathrm{~cm}$ & $31-004-02$ & Burned Rock & 65 & 2948.40 \\
\hline 32 & Test Unit 4 & 1 & $0-10 \mathrm{~cm}$ & $32-001$ & Charcoal & 1. & 0000.00 \\
\hline 32 & Test Unit 4 & 1 & $0-10 \mathrm{~cm}$ & $32-002$ & Lithics & 2 & 0000.00 \\
\hline 32 & Test Unit 4 & 1 & $0-10 \mathrm{~cm}$ & $32-003$ & Burned Rock & 7 & 0037.60 \\
\hline 32 & Test Unit 4 & 1 & $0-10 \mathrm{~cm}$ & 32-004 & Snail Shell & 1 & 0000.00 \\
\hline 32 & Test Unit 4 & 1 & $0-10 \mathrm{~cm}$ & 32-005 & Soil Sample/Flotation & 1 & 0000.00 \\
\hline 33 & Test Unit 4 & 2 & $10-20 \mathrm{~cm}$ & 33-001 & Soil Sample/Flotation & 1 & 0000.00 \\
\hline 33 & Test Unit 4 & 2 & $10-20 \mathrm{~cm}$ & 33-002 & Snail Shell & 1 & 0000.00 \\
\hline 33 & Test Unit 4 & 2 & $10-20 \mathrm{~cm}$ & $33-003$ & Burned Rock & 6 & 0388.00 \\
\hline 33 & Test Unit 4 & 2 & $10-20 \mathrm{~cm}$ & 33-004 & Lithics & 4 & 0000.00 \\
\hline 34 & Test Unit 4 & 3 & $20-30 \mathrm{~cm}$ & $34-001$ & Burned Rock & 7 & 0178.30 \\
\hline 34 & Test Unit 4 & 3 & $20-30 \mathrm{~cm}$ & $34-002$ & Lithics & 1 & 0000.00 \\
\hline 34 & Test Unit 4 & 3 & $20-30 \mathrm{~cm}$ & $34-004$ & Snail Shell & 1 & 0000.00 \\
\hline 35 & Test Unit 4 & 4 & $30-45 \mathrm{~cm}$ & $35-001$ & Snail Shell & 1 & 0000.00 \\
\hline 35 & Test Unit 4 & 4 & $30-45 \mathrm{~cm}$ & $35-002$ & Mussel Shell & 1 & 0000.00 \\
\hline 35 & Test Unit 4 & 4 & $30-45 \mathrm{~cm}$ & $35-003$ & Burned Rock & 9 & 0135.60 \\
\hline 35 & Test Unit 4 & 4 & $30-45 \mathrm{~cm}$ & $35-004$ & Lithics & 3 & 0000.00 \\
\hline 36 & Test Unit 5 & 1 & $0-10 \mathrm{~cm}$ & $36-001$ & Lithics & 14 & 0000.00 \\
\hline 36 & Test Unit 5 & 1 & $0-10 \mathrm{~cm}$ & $36-002$ & Burned Rock & 48 & 0807.50 \\
\hline 36 & Test Unit 5 & 1 & $0-10 \mathrm{~cm}$ & $36-003$ & Snail Shell & 1 & 0000.00 \\
\hline 36 & Test Unit 5 & 1 & $0-10 \mathrm{~cm}$ & 36-004 & Charcoal & 1 & 0000.00 \\
\hline 36 & Test Unit 5 & 1 & $0-10 \mathrm{~cm}$ & $36-005$ & Charcoal & 1 & 0000.00 \\
\hline 36 & Test Unit 5 & 2 & $10-20 \mathrm{~cm}$ & $36-006$ & Point & 1 & 0000.00 \\
\hline 37 & Test Unit 5 & 2 & $10-20 \mathrm{~cm}$ & $37-001$ & Soil Sample/Flotation & 1 & 0000.00 \\
\hline 37 & Test Unit 5 & 2 & $10-20 \mathrm{~cm}$ & $37-002$ & Charcoal & 1 & 0000.00 \\
\hline 37 & Test Unit 5 & 2 & $10-20 \mathrm{~cm}$ & $37-004$ & Snail Shell & 1. & 0000.00 \\
\hline 37 & Test Unit 5 & 2 & $10-20 \mathrm{~cm}$ & $37-005$ & Burned Rock & 141 & 0873.60 \\
\hline 37 & Test Unit 5 & 2 & $10-20 \mathrm{~cm}$ & $37-006$ & Bone & 21 & 0000.00 \\
\hline 37 & Test Unit 5 & 2 & $10-20 \mathrm{~cm}$ & $37-007$ & Lithics & 180 & 0000.00 \\
\hline 37 & Test Unit 5 & 2 & $10-20 \mathrm{~cm}$ & $37-008$ & Charcoal & 1 & 0000.00 \\
\hline
\end{tabular}


Table B-1. Continued...

\begin{tabular}{|c|c|c|c|c|c|c|c|}
\hline Lot No. & Unit & Level & Depth & Catalog No. & Class & Count & Weight (g) \\
\hline 37 & Test Unit 5 & 2 & $10-20 \mathrm{~cm}$ & $37-009$ & Point & 1 & 0000.00 \\
\hline 37 & Test Unit 5 & 2 & $10-20 \mathrm{~cm}$ & $37-010$ & Charcoal & 1 & 0000.00 \\
\hline 37 & Test Unit 5 & 2 & $10-20 \mathrm{~cm}$ & $37-011$ & Charcoal & 1 & 0000.00 \\
\hline 37 & Test Unit 5 & 2 & $10-20 \mathrm{~cm}$ & $37-012$ & Charcoal & 1 & 0000.00 \\
\hline 37 & Test Unit 5 & 2 & $10-20 \mathrm{~cm}$ & $37-013$ & Bone & 28 & 0000.00 \\
\hline 38 & Test Unit 5 & 3 & $20-30 \mathrm{~cm}$ & $38-001$ & Charcoal & 1 & 0000.00 \\
\hline 38 & Test Unit 5 & 3 & $20-30 \mathrm{~cm}$ & $38-002$ & Soil Sample/Flotation & 1 & 0000.00 \\
\hline 38 & Test Unit 5 & 3 & $20-30 \mathrm{~cm}$ & $38-003$ & Lithics & 166 & 0000.00 \\
\hline 38 & Test Unit 5 & 3 & $20-30 \mathrm{~cm}$ & $38-004$ & Snail Shell & 1. & 0000.00 \\
\hline 38 & Test Unit 5 & 3 & $20-30 \mathrm{~cm}$ & $38-005$ & Burned Rock & 199 & 3628.70 \\
\hline 38 & Test Unit 5 & 3 & $20-30 \mathrm{~cm}$ & $38-006$ & Bone & 8 & 0000.00 \\
\hline 38 & Test Unit 5 & 3 & $20-30 \mathrm{~cm}$ & $38-007$ & Charcoal & 1 & 0000.00 \\
\hline 38 & Test Unit 5 & 3 & $20-30 \mathrm{~cm}$ & $38-008$ & Charcoal & 1 & 0000.00 \\
\hline 38 & Test Unit 5 & 3 & $20-30 \mathrm{~cm}$ & $38-009$ & Tool & 2 & 0000.00 \\
\hline 38 & Test Unit 5 & 3 & $20-30 \mathrm{~cm}$ & $38-010$ & Other & 1 & 0000.00 \\
\hline 39 & Test Unit 5 & 4 & $30-40 \mathrm{~cm}$ & $39-001$ & Lithics & 135 & 0000.00 \\
\hline 39 & Test Unit 5 & 4 & $30-40 \mathrm{~cm}$ & $39-002$ & Snail Shell & 1 & 0000.00 \\
\hline 39 & Test Unit 5 & 4 & $30-40 \mathrm{~cm}$ & $39-003$ & Charcoal & 1 & 0000.00 \\
\hline 39 & Test Unit 5 & 4 & $30-40 \mathrm{~cm}$ & $39-004$ & Soil Sample/Flotation & 1 & 0000.00 \\
\hline 39 & Test Unit 5 & 4 & $30-40 \mathrm{~cm}$ & $39-005-01$ & Burned Rock & 76 & 3340.10 \\
\hline 39 & Test Unit 5 & 4 & $30-40 \mathrm{~cm}$ & $39-005-02$ & Burned Rock & 34 & 5640.80 \\
\hline 39 & Test Unit 5 & 4 & $30-40 \mathrm{~cm}$ & $39-005-03$ & Burned Rock & 53 & 4658.90 \\
\hline 39 & Test Unit 5 & 4 & $30-40 \mathrm{~cm}$ & $39-005-04$ & Burned Rock & 51 & 5522.00 \\
\hline 39 & Test Unit 5 & 4 & $30-40 \mathrm{~cm}$ & 39-005-05 & Burned Rock & 51 & 5049.00 \\
\hline 39 & Test Unit 5 & 4 & $30-40 \mathrm{~cm}$ & $39-006$ & Tool & 1 & 0000.00 \\
\hline 39 & Test Unit 5 & 4 & $30-40 \mathrm{~cm}$ & $39-008$ & Charcoal & 1 & 0000.00 \\
\hline 39 & Test Unit 5 & 4 & $30-40 \mathrm{~cm}$ & $39-009$ & Charcoal & 1 & 0000.00 \\
\hline 39 & Test Unit 5 & 4 & $30-40 \mathrm{~cm}$ & $39-011$ & Tool & 1 & 0000.00 \\
\hline 39 & Test Unit 5 & 4 & $30-40 \mathrm{~cm}$ & $39-012$ & Mussel Shell & 1 & 0000.00 \\
\hline 40 & Test Unit 5 & 4 & $30-40 \mathrm{~cm}$ & $40-001$ & Charcoal & 1 & 0000.00 \\
\hline 40 & Test Unit 5 & 4 & $30-40 \mathrm{~cm}$ & $40-002$ & Charcoal & 1 & 0000.00 \\
\hline 41 & Test Unit 5 & 5 & $40-50 \mathrm{~cm}$ & $41-001$ & Soil Sample/Flotation & 1 & 0000.00 \\
\hline 42 & Test Unit 5 & 5 & $40-50 \mathrm{~cm}$ & $42-001-01$ & Burned Rock & 81 & 2674.10 \\
\hline 42 & Test Unit 5 & 5 & $40-50 \mathrm{~cm}$ & 42-001-02 & Burned Rock & 64 & 4586.80 \\
\hline 42 & Test Unit 5 & 5 & $40-50 \mathrm{~cm}$ & $42-002$ & Tool & 1 & 0000.00 \\
\hline 42 & Test Unit 5 & 5 & $40-50 \mathrm{~cm}$ & $42-003$ & Snail Shell & 1 & 0000.00 \\
\hline 42 & Test Unit 5 & 5 & $40-50 \mathrm{~cm}$ & $42-004$ & Lithics & 131 & 0000.00 \\
\hline 42 & Test Unit 5 & 5 & $40-50 \mathrm{~cm}$ & $42-005$ & Charcoal & 1 & 0000.00 \\
\hline 42 & Test Unit 5 & 5 & $40-50 \mathrm{~cm}$ & $42-006$ & Charcoal & 1 & 0000.00 \\
\hline 42 & Test Unit 5 & 5 & $40-50 \mathrm{~cm}$ & $42-008$ & Bone & 3 & 0000.00 \\
\hline 42 & Test Unit 5 & 5 & $40-50 \mathrm{~cm}$ & $42-009$ & Mussel Shell & 1 & 0000.00 \\
\hline 43 & Test Unit 5 & 6 & $50-60 \mathrm{~cm}$ & $43-001$ & Soil Sample/Flotation & 1 & 0000.00 \\
\hline 43 & Test Unit 5 & 6 & $50-60 \mathrm{~cm}$ & $43-002-01$ & Burned Rock & 93 & 4082.30 \\
\hline 43 & Test Unit 5 & 6 & $50-60 \mathrm{~cm}$ & $43-002-02$ & Burned Rock & 33 & 0021.30 \\
\hline 43 & Test Unit 5 & 6 & $50-60 \mathrm{~cm}$ & $43-003$ & Charcoal & 1 & 0000.00 \\
\hline 43 & Test Unit 5 & 6 & $50-60 \mathrm{~cm}$ & $43-004$ & Bone & 1 & 0000.00 \\
\hline 43 & Test Unit 5 & 6 & $50-60 \mathrm{~cm}$ & $43-005$ & Snail Shell & 1 & 0000.00 \\
\hline 43 & Test Unit 5 & 6 & $50-60 \mathrm{~cm}$ & $43-006$ & Lithics & 133 & 0000.00 \\
\hline 43 & Test Unit 5 & 6 & $50-60 \mathrm{~cm}$ & $43-007$ & Point & 1. & 0000.00 \\
\hline 43 & Test Unit 5 & 6 & $50-60 \mathrm{~cm}$ & $43-008$ & Core & 1 & 0000.00 \\
\hline 44 & Test Unit 5 & 7 & $60-70 \mathrm{~cm}$ & $44-001$ & Snail Shell & 1 & 0000.00 \\
\hline 44 & Test Unit 5 & 7 & $60-70 \mathrm{~cm}$ & $44-002$ & Lithics & 45 & 0000.00 \\
\hline 44 & Test Unit 5 & 7 & $60-70 \mathrm{~cm}$ & $44-003$ & Soil Sample/Flotation & 1 & 0000.00 \\
\hline 44 & Test Unit 5 & 7 & $60-70 \mathrm{~cm}$ & $44-004$ & Charcoal & 1 & 0000.00 \\
\hline 44 & Test Unit 5 & 7 & $60-70 \mathrm{~cm}$ & $44-005$ & Bone & 2 & 0000.00 \\
\hline 44 & Test Unit 5 & 7 & $60-70 \mathrm{~cm}$ & $44-006-01$ & Burned Rock & 30 & 0782.20 \\
\hline 44 & Test Unit 5 & 7 & $60-70 \mathrm{~cm}$ & $44-006-02$ & Burned Rock & 22 & 0044.20 \\
\hline 45 & Test Unit 5 & 8 & $70-80 \mathrm{~cm}$ & $45-001$ & Bone & 3 & 0000.00 \\
\hline 45 & Test Unit 5 & 8 & $70-80 \mathrm{~cm}$ & $45-002$ & Snail Shell & 1 & 0000.00 \\
\hline 45 & Test Unit 5 & 8 & $70-80 \mathrm{~cm}$ & $45-003$ & Lithics & 33 & 0000.00 \\
\hline 45 & Test Unit 5 & 8 & $70-80 \mathrm{~cm}$ & $45-004$ & Charcoal & 1 & 0000.00 \\
\hline
\end{tabular}


Table B-1. Continued...

\begin{tabular}{|c|l|l|l|l|l|r|r|}
\hline Lot No. & Unit & Level & \multicolumn{1}{|c|}{ Depth } & Catalog No. & Class & Count & Weight (g) \\
\hline 45 & Test Unit 5 & 8 & $70-80 \mathrm{~cm}$ & $45-005-01$ & Burned Rock & 7 & 0315.00 \\
\hline 45 & Test Unit 5 & 8 & $70-80 \mathrm{~cm}$ & $45-005-02$ & Burned Rock & 10 & 0024.70 \\
\hline 45 & Test Unit 5 & 8 & $70-80 \mathrm{~cm}$ & $45-006$ & Soil Sample/Flotation & 1 & 0000.00 \\
\hline 46 & Test Unit 5 & 9 & $80-90 \mathrm{~cm}$ & $46-002$ & Charcoal & 1 & 0000.00 \\
\hline 46 & Test Unit 5 & 9 & $80-90 \mathrm{~cm}$ & $46-003$ & Snail Shell & 1 & 0000.00 \\
\hline 46 & Test Unit 5 & 9 & $80-90 \mathrm{~cm}$ & $46-004$ & Lithics & 14 & 0000.00 \\
\hline 46 & Test Unit 5 & 9 & $80-90 \mathrm{~cm}$ & $46-005-01$ & Burned Rock & 9 & 1259.40 \\
\hline 46 & Test Unit 5 & 9 & $80-90 \mathrm{~cm}$ & $46-005-02$ & Burned Rock & 6 & 0124.70 \\
\hline 46 & Test Unit 5 & 9 & $80-90 \mathrm{~cm}$ & $46-006$ & Bone & 2 & 0000.00 \\
\hline 47 & Test Unit 5 & 10 & $90-100 \mathrm{~cm}$ & $47-001$ & Soil Sample/Flotation & 1 & 0000.00 \\
\hline 47 & Test Unit 5 & 10 & $90-100 \mathrm{~cm}$ & $47-002$ & Snail Shell & 1 & 0000.00 \\
\hline 47 & Test Unit 5 & 10 & $90-100 \mathrm{~cm}$ & $47-003$ & Lithics & 4 & 0000.00 \\
\hline 47 & Test Unit 5 & 10 & $90-100 \mathrm{~cm}$ & $47-004$ & Charcoal & 1 & 0000.00 \\
\hline 47 & Test Unit 5 & 10 & $90-100 \mathrm{~cm}$ & $47-005$ & Burned Rock & 6 & 0472.70 \\
\hline 48 & Test Unit 5 & 11 & $100-110 \mathrm{~cm}$ & $48-001$ & Soil Sample/Flotation & 1 & 0000.00 \\
\hline 48 & Test Unit 5 & 11 & $100-110 \mathrm{~cm}$ & $48-002$ & Lithics & 2 & 0000.00 \\
\hline 48 & Test Unit 5 & 11 & $100-110 \mathrm{~cm}$ & $48-003$ & Snail Shell & 1 & 0000.00 \\
\hline 49 & Shovel Test 2 & 3 & $20-30 \mathrm{~cm}$ & $49-001$ & Lithics & 1 & 0000.00 \\
\hline 50 & Shovel Test 2 & 5 & $40-50 \mathrm{~cm}$ & $50-001$ & Lithics & Burned Rock & 1 \\
\hline 50 & Shovel Test 2 & 5 & $40-50 \mathrm{~cm}$ & $50-002$ & Soil Sample/Flotation & 1 & 0000.00 \\
\hline 51 & Test Unit 1 & 8 & $70-80 \mathrm{~cm}$ & $51-001$ & Lithics & 0027.00 \\
\hline 51 & Test Unit 1 & 8 & $70-80 \mathrm{~cm}$ & $51-002$ & Burned Rock & 0000.00 \\
\hline 51 & Test Unit 1 & 8 & $70-80 \mathrm{~cm}$ & $51-003$ & Bone & 0000.00 \\
\hline 52 & Test Unit 1 & 7 & $60-70 \mathrm{~cm}$ & $52-001$ & $50-70 \mathrm{~cm}$ & $52-002$ & 0083.80 \\
\hline 52 & Test Unit 1 & 7 & & & 0000.00 \\
\hline & & & & & 0000.00 \\
\hline
\end{tabular}




\section{Appendix C}

\section{Radiocarbon Results}




\begin{tabular}{|c|c|c|c|}
\hline Sample Data & $\begin{array}{c}\text { Measured } \\
\text { Radiocarbon Age }\end{array}$ & $\begin{array}{c}13 \mathrm{C} / 12 \mathrm{C} \\
\text { Ratio }\end{array}$ & $\begin{array}{c}\text { Conventional } \\
\left.\text { Radiocarbon Age( }{ }^{*}\right)\end{array}$ \\
\hline $\begin{array}{l}\text { Beta - } 163782 \\
\text { SAMPLE : 06-006 } \\
\text { ANALYSIS : Radiometric-Sta } \\
\text { MATERIAL/PRETREATMEI } \\
2 \text { SIGMA CALIBRATION : }\end{array}$ & $\begin{array}{l}170+/-80 \mathrm{BP} \\
\mathrm{y} \text { (with extended count } \\
\text { material): acid/alkali/c } \\
1490 \text { to } 1960(\mathrm{Cal} \mathrm{BP}\end{array}$ & $-23.9 \mathrm{o} / 00$ & $190+/-90 \mathrm{BP}$ \\
\hline $\begin{array}{l}\text { Beta - } 163783 \\
\text { SAMPLE : 08-002 } \\
\text { ANALYSIS : Radiometric-Sta } \\
\text { MATERIAL/PRETREATMEl } \\
2 \text { SIGMA CALIBRATION : }\end{array}$ & $\begin{array}{l}1050+/-60 \mathrm{BP} \\
\mathrm{y} \text { (with extended count } \\
\text { material): acid/alkali/s } \\
870 \text { to } 1040(\mathrm{Cal} \mathrm{BP} 1\end{array}$ & $-23.9 \mathrm{o} / 00$ & $1070+/-60 \mathrm{BP}$ \\
\hline $\begin{array}{l}\text { Beta - } 163784 \\
\text { SAMPLE : 11-002 } \\
\text { ANALYSIS : AMS-Standard } \\
\text { MATERIAL/PRETREATMEI } \\
2 \text { SIGMA CALIBRATION : }\end{array}$ & $\begin{array}{l}1620+/-40 \mathrm{BP} \\
\text { material): acid/alkali/s } \\
370 \text { to } 540 \text { (Cal BP } 15\end{array}$ & $-25.3 \mathrm{o} / 00$ & $1620+/-40 \mathrm{BP}$ \\
\hline $\begin{array}{l}\text { Beta - } 163785 \\
\text { SAMPLE : } 37-002 \\
\text { ANALYSIS : Radiometric-Sta } \\
\text { MATERIAL/PRETREATMEI } \\
2 \text { SIGMA CALIBRATION : }\end{array}$ & $\begin{array}{l}70+/-40 \mathrm{BP} \\
\mathrm{y} \text { (with extended count } \\
\text { material): acid/alkali/s } \\
\text { s outside of the calibrat }\end{array}$ & $-24.4 \mathrm{o} / 00$ & $80+/-40 \mathrm{BP}$ \\
\hline $\begin{array}{l}\text { Beta - } 163786 \\
\text { SAMPLE : } 38-001 \\
\text { ANALYSIS : Radiometric-Sta } \\
\text { MATERIAL/PRETREATMEI } \\
2 \text { SIGMA CALIBRATION : }\end{array}$ & $\begin{array}{l}270+/-90 \mathrm{BP} \\
\text { (with extended count } \\
\text { material): acid/alkali/c } \\
440 \text { to } 1890 \text { (Cal BP }\end{array}$ & $-25.0 \mathrm{o} / 00$ & $270+/-90 \mathrm{BP}$ \\
\hline
\end{tabular}




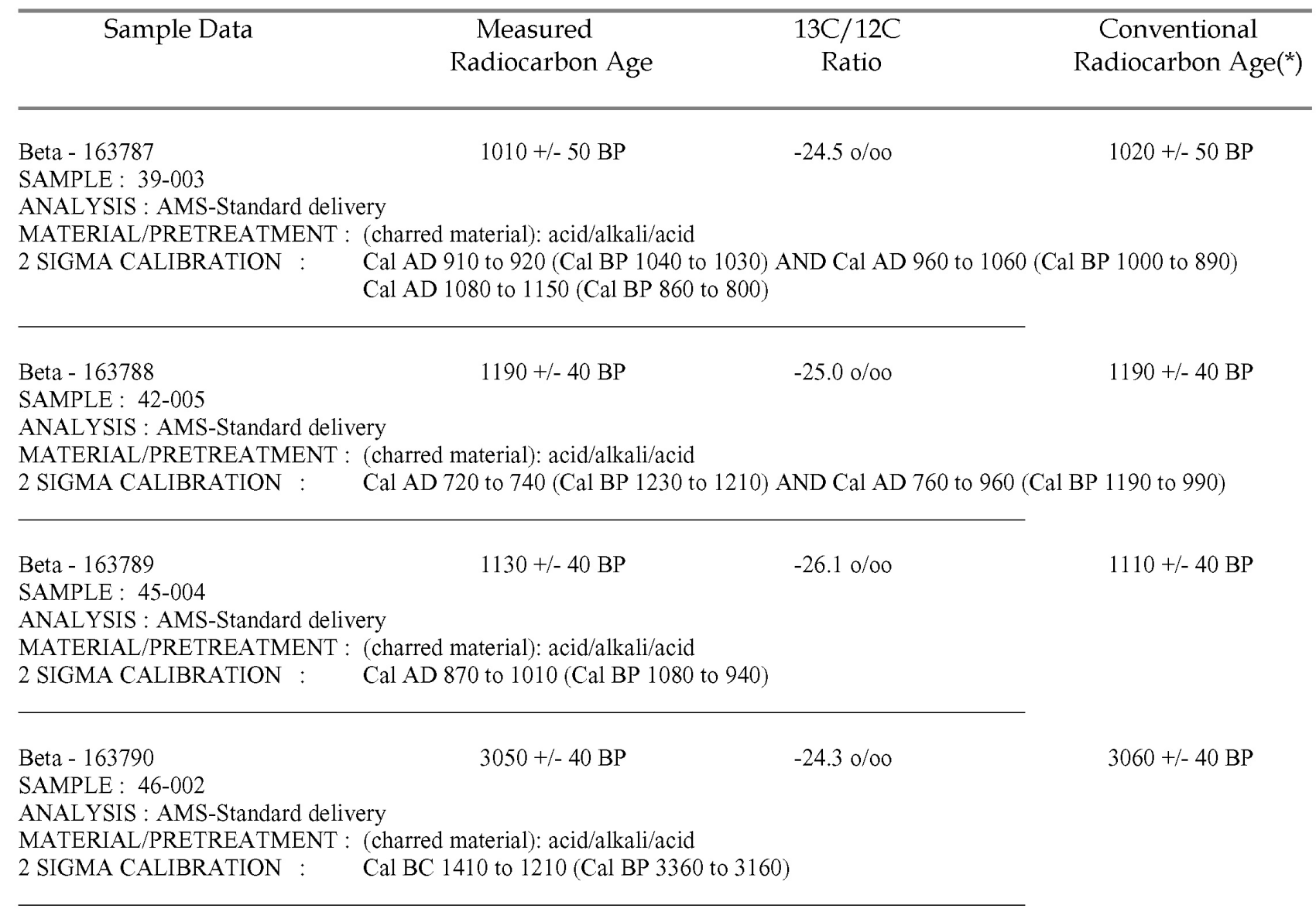




\section{CALIBRATION OF RADIOCARBON AGE TO CALENDAR YEARS}

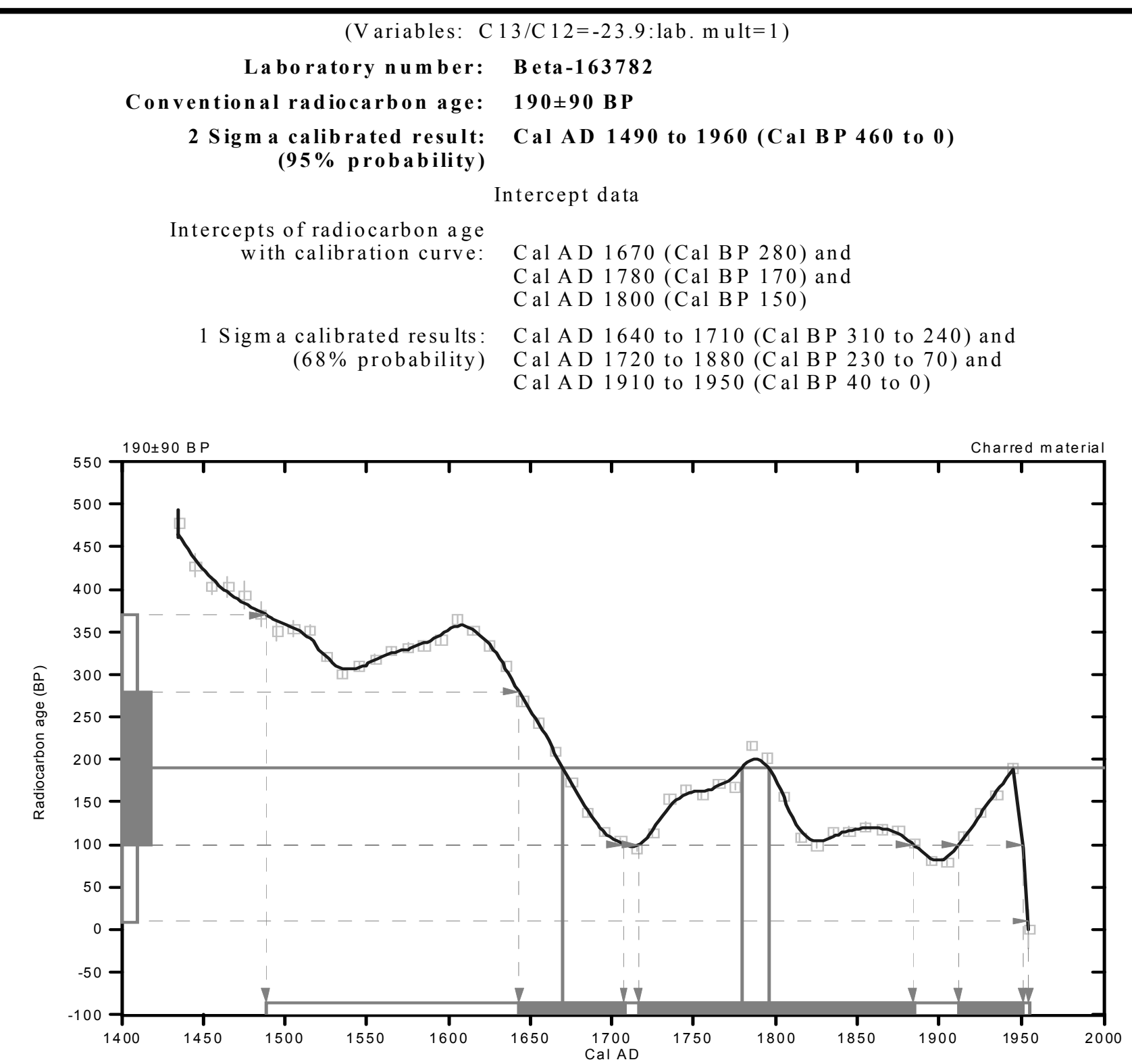

References:

Da tabase used

Calibration Databa se

Editorial Com ment

Stuiver, M., van der Plicht, H., 1998, Radiocarbon 40(3), pxii-xiii

INTCAL98 Radiocarbon Age Calibration

Stuiver, M., et. al., 1998, Radiocarbon 40(3), p1041-1083

Math em atics

A Simplified Approach to Calibrating C14 Dates

Talma, A. S., Vogel, J. C., 1993 , Radiocarbon 35(2), p317-322

\section{Beta Analytic Inc.}

4985 SW 74 Court, Miami, Florida 33155 USA Tel: (305)6675167•Fax: (305)6630964・E-Mail: beta@ radiocarbon.com 


\section{CALIBRATION OFRADIOCARBON AGE TO CALENDAR YEARS}

(V ariables: C 13/C 12=-23.9:1ab. mult=1)

Laboratory number: Beta-163783

Conventional radiocarbon age: $1070 \pm 60 \mathrm{BP}$

2 Sigm a calibrated result: Cal AD 870 to 1040 (Cal B P 1080 to 910)

(95\% probability)

Intercept data

Intercept of radiocarbon age

with calibration curve: Cal A D 990 (Cal B P 960)

1 Sigma calibrated result: Cal A D 900 to 1020 (Cal B P 1050 to 930 )

(68\% probability)

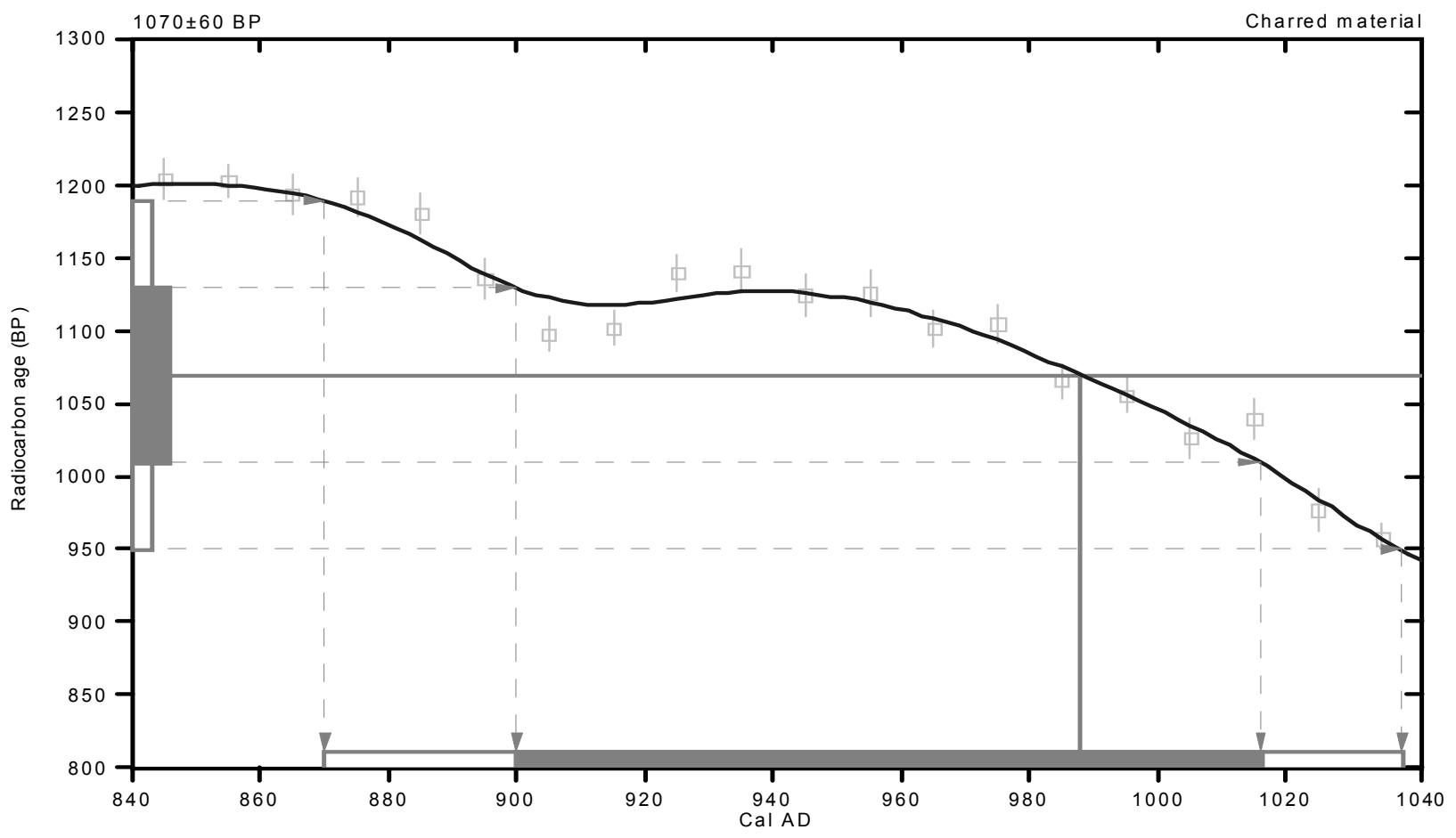

References:

Database used

Calibration Database

Editorial Com ment

Stuiver, M., van der Plicht, H., 1998, Radiocarbon 40(3), pxii-xiii

INTCAL98 Radiocarbon Age Calibration

Stuiver, M., et. al., 1998, Radiocarbon 40(3), p1041-1083

Mathematics

A Simplified Approach to Calibrating C14 Dates

Talma, A. S., Vogel, J. C., 1993, Radiocarbon 3 5(2), p317-322

\section{Beta Analytic Inc.}

4985 SW 74 Court, Miami, Florida 33155 USA Tel: (305)6675167•Fax:(305)6630964・E-Mail: beta@radiocarbon.com 


\section{CALIBRATION OF RADIOCARBON AGE TO CALENDAR YEARS}

(Variables: C $13 /$ C $12=-25.3: 1 \mathrm{ab} . \mathrm{mult}=1$ )

Laboratory number: Beta-163784

Conventional radiocarbon age: $1620 \pm 40 \mathrm{BP}$

2 Sigm a calibrated result: Cal AD 370 to 540 (Cal B P 1580 to 1410)

$(95 \%$ probability $)$

Intercept data

Intercept of radiocarbon age

with calibration curve: Cal A D 420 (Cal B P 1530)

1 Sigma calibrated result: Cal A D 400 to 450 (Cal B P 1550 to 1500) (68\% probability)

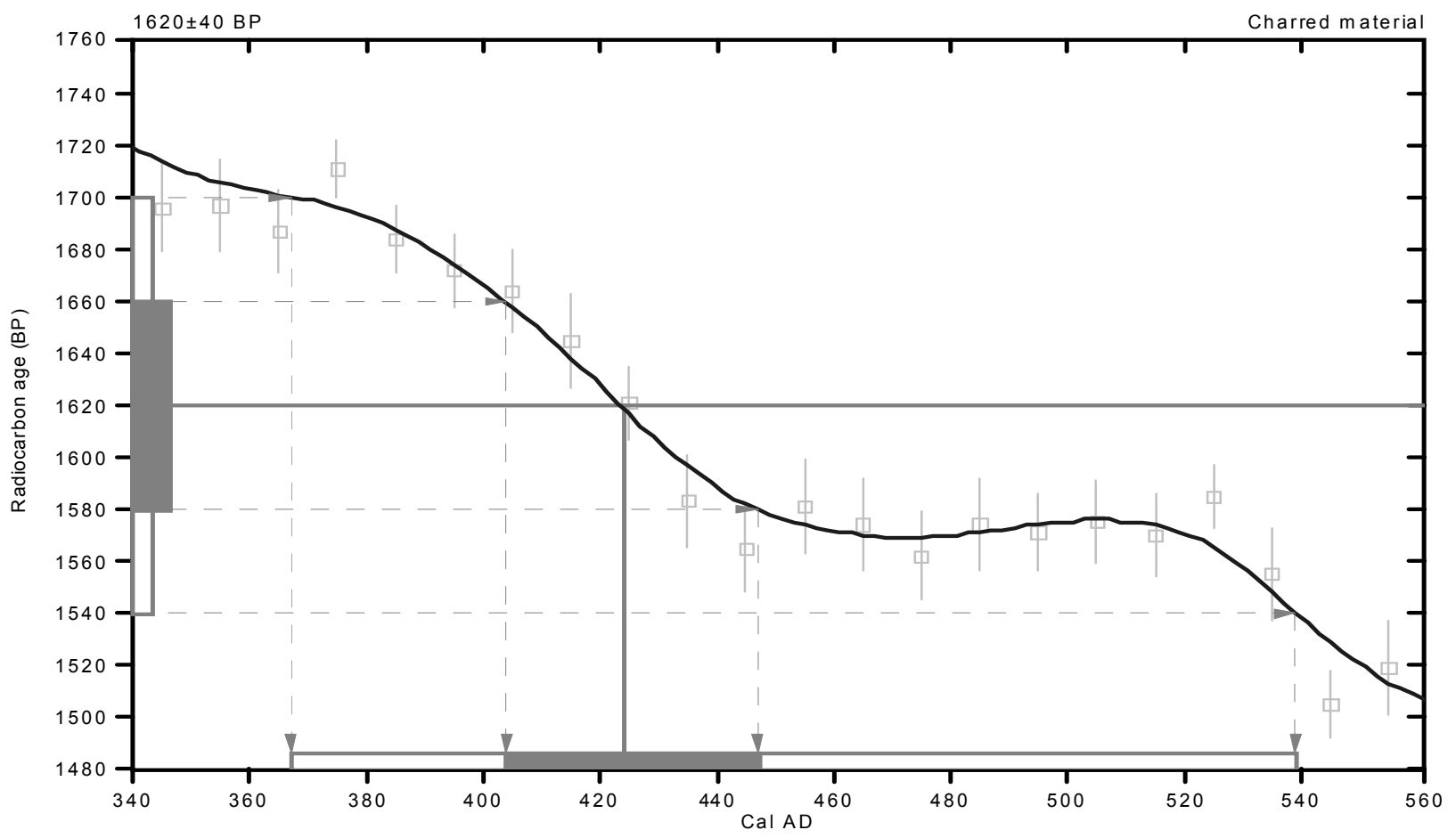

References:

Da tabase used

Calibration Database

Editorial Com ment

Stuiver, M., van der Plicht, H., 1998, Radiocarbon 40(3), pxii-xiii

IN TCAL98 Radiocarbon Age Calibration

Stuiver, M., et. al., 1998, Radiocarbon 40(3), p1041-1083

$M$ ath em atics

A Simplified Approach to Calibrating C14 Dates

Talma, A. S., Vogel, J. C., 1993, Radiocarbon 35(2), p317-322

\section{Beta Analytic Inc.}

4985 SW 74 Court, Miami, Florida 33155 USA Pel: (305)6675167•Fax: (305)6630964・E-Mail: beta@ radiocarbon.com 


\title{
CALIBRATION OF RADIOCARBON AGE TO CALENDAR YEARS
}

(Variables: C $13 / \mathrm{C} 12=-25:$ lab. mult $=1$ )

\author{
Laboratory number: Beta-163786
}

Conventional radiocarbon age: $270 \pm 90$ B $P$

2 Sigma calibrated results: Cal AD 1440 to 1890 (Cal B P 510 to 60) and (95\% probability) Cal AD 1910 to 1950 (Cal B P 40 to 0 )

Intercept data

Intercept of radiocarbon age

with calibration curve:

Cal A D 1650 (Cal B P 300)

$1 \mathrm{Sigm}$ a calibrated results: (68\% probability)

Cal A D 1500 to 1670 (Cal B P 450 to 280) and

Cal A D 1770 to 1800 (Cal B P 180 to 150 ) and

Cal A D 1940 to 1950 (Cal B P 10 to 0)

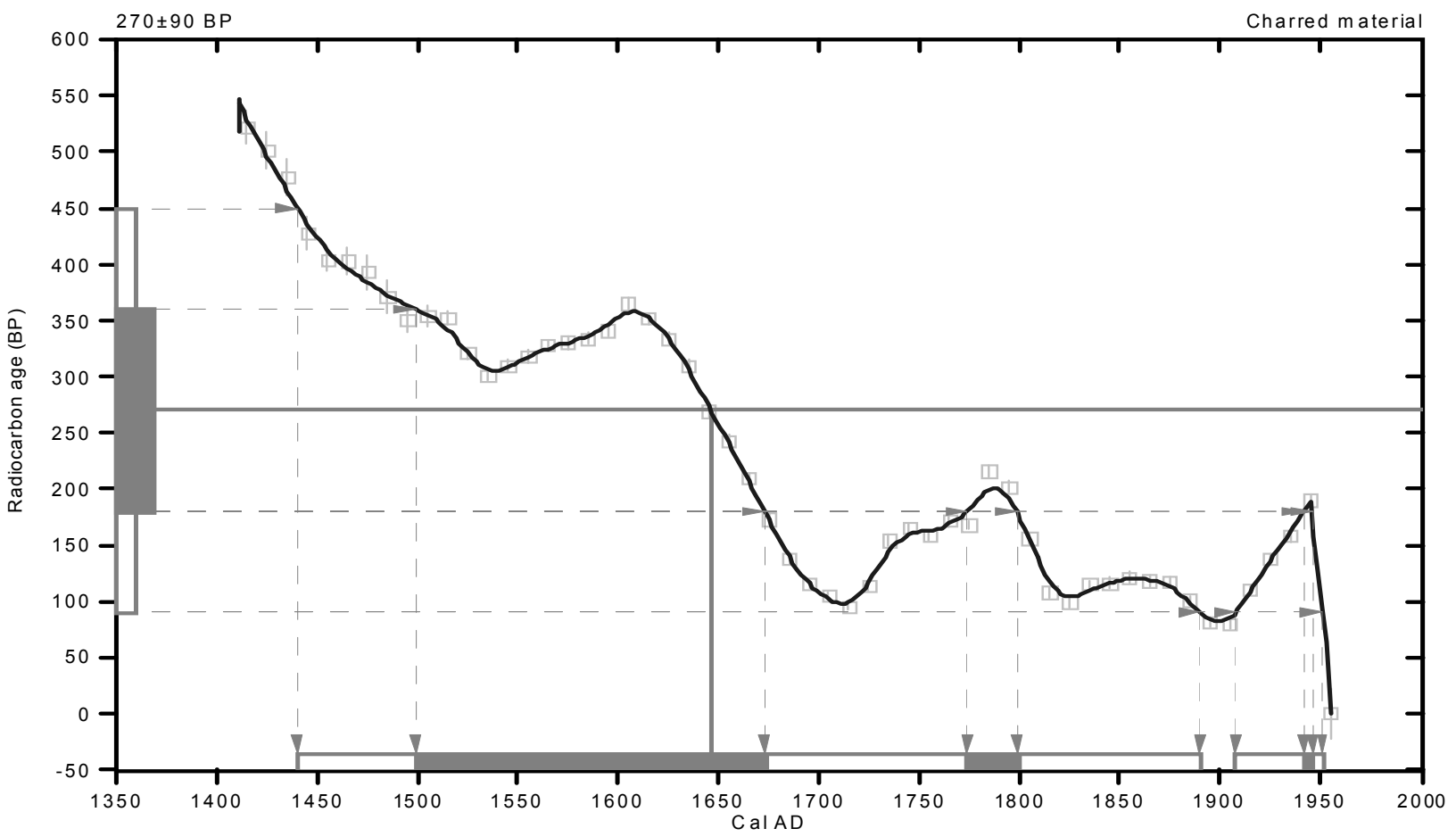

References:

Database used

Calibration Database

Editorial Com ment

Stuiver, M., van der Plicht, H., 1998, Radiocarbon 40(3), pxii-xiii

IN TCAL 98 Radiocarbon Age Calibration

Stuiver, M., et. al., 1998, Radiocarbon 40(3), p1041-1083

$M$ ath ematics

A Simplified Approach to Calibrating C14 Dates

Talma, A.S., Vogel, J. C., 1993 , Radiocarbon 3 5(2), p317-322

\section{Beta Analytic Inc.}

4985 SW74 Court, Miami, Florida 33155 USA Tel: (305)6675167•Fax:(305)6630964・E-Mail: beta@radiocarbon.com 


\section{CALIBRATION OF RADIOCARBON AGE TO CALENDAR YEARS}

(Variables: C 13/C 12=-24.5:lab. mult $=1$ )

Laboratory number: Beta-163787

Conventional radiocarbon age: $1020 \pm 50$ BP

2 Sigm a calibrated results: Cal AD 910 to 920 (Cal BP 1040 to 1030) and (95\% probability) Cal AD 960 to 1060 (Cal B P 1000 to 890) and

Cal AD 1080 to 1150 (Cal BP 860 to 800)

Intercept data

Intercept of radiocarbon age with calibration curve:

1 Sigma calibrated result: Cal A D 990 to 1030 (Cal B P 960 to 920) (68\% probability)

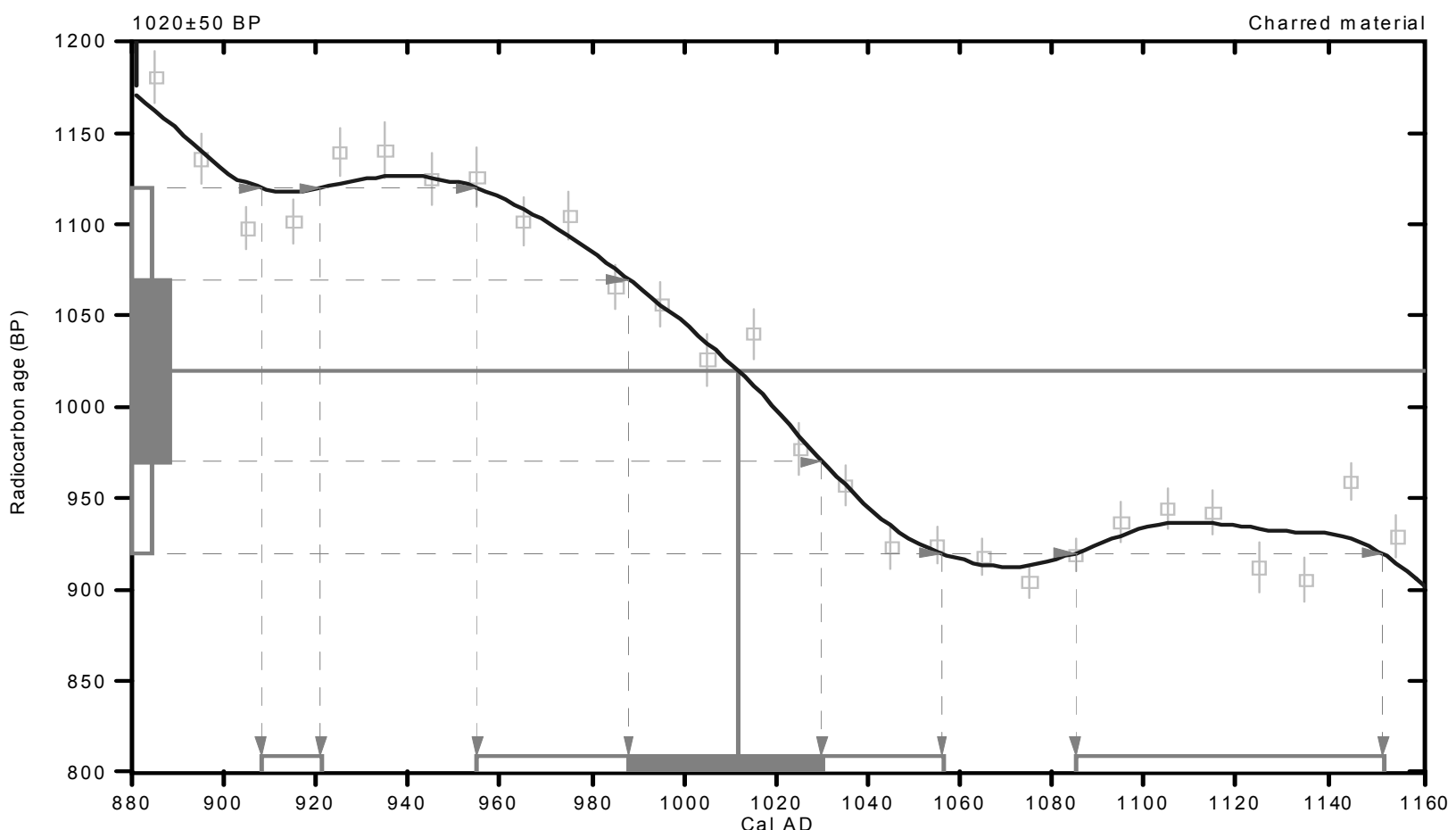

References:

Database used

Calibration Database

Editorial Com ment

Stuiver, M., van der Plicht, H., 1998, Radiocarbon 40(3), pxii-xiii

IN TCAL 98 Radiocarbon Age Calibration

Stuiver, M., et. al., 1998, Radiocarbon 40(3), p1041-1083

Math ematics

A Simplified Approach to Calibrating C14 Dates

Talma, A.S., Vogel, J. C., 1993 , Radiocarbon 3 5(2), p317-322

\section{Beta Analytic Inc.}

4985 SW 74 Court, Miami, Florida 33155 USA $\cdot$ Tel: (305)6675167•Fax:(305)6630964・E-Mail: beta@radiocarbon.com 


\title{
CALIBRATION OF RADIOCARBON AGE TO CALENDAR YEARS
}

(V ariables: C $13 / \mathrm{C} 12=-25:$ lab. mult $=1$ )

\author{
Laboratory number: B eta-163788
}

Conventional radiocarbon age: $1190 \pm 40 \mathrm{BP}$

2 Sigm a calibrated results: Cal AD 720 to 740 (Cal B P 1230 to 1210) and (95\% probability) Cal AD 760 to 960 (Cal B P 1190 to 990)

Intercept data

Intercept of radiocarbon age with calibration curve:

1 Sigm a calibrated result: Cal A D 780 to 890 (Cal B P 1170 to 1060) $(68 \%$ probability)

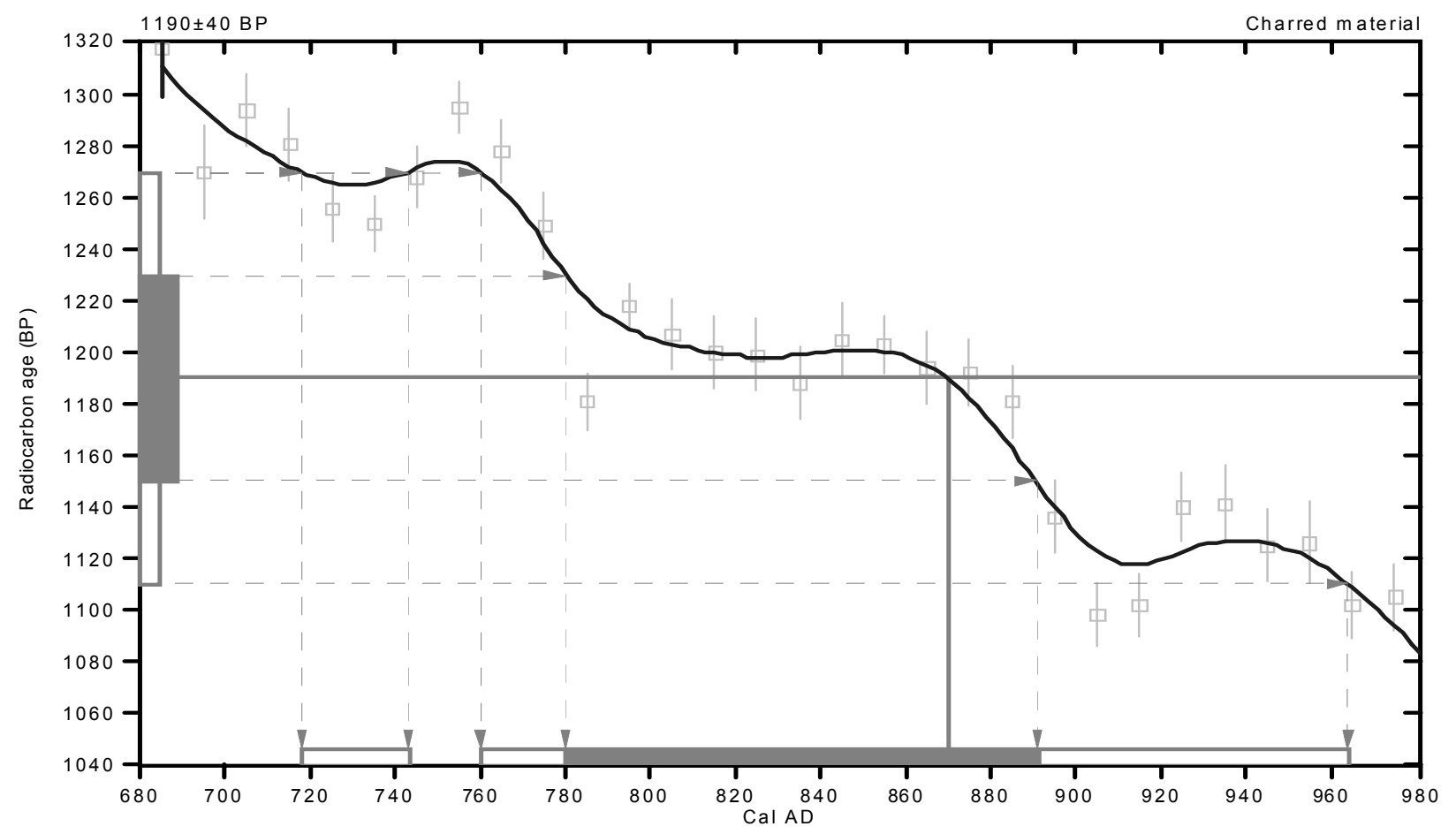

References:

Database used

Calibration Database

Editorial Com ment

Stuiver, M., van der Plicht, H., 1998, Radioca rbon 40(3), pxii-xiii

IN TCAL98 Radiocarbon Age Calibration

Stuiver, M., et. al., 1998, Radiocarbon 40(3), p1041-1083

$M$ ath ematics

A Simplified Approach to Calibrating C14 Dates

Talm a, A. S., Vogel, J. C., 1993, Radiocarbon 3 5(2), p317-322

\section{Beta Analytic Inc.}

4985 SW74 Court, Miami, Florida 33155 USA Tel: (305)6675167•Fax:(305)6630964・E-Mail: beta@radiocarbon.com 


\section{CALIBRATION OF RADIOCARBON AGE TO CALENDAR YEARS}

(V ariables: C $13 / \mathrm{C} 12=-26.1: 1 \mathrm{lab} . \mathrm{mult}=1$ )

Laboratory number: Beta-163789

Conventional radiocarbon age: $1110 \pm 40 \mathrm{BP}$

2 Sigm a calibrated result: Cal AD 870 to 1010 (Cal B P 1080 to 940)

(95\% probability)

Intercept data

Intercept of radiocarbon age

with calibration curve:

Cal A D 960 (Cal B P 990)

1 Sigm a calibrated result:

Cal A D 890 to 990 (Cal B P 1060 to 960) (68\% probability)

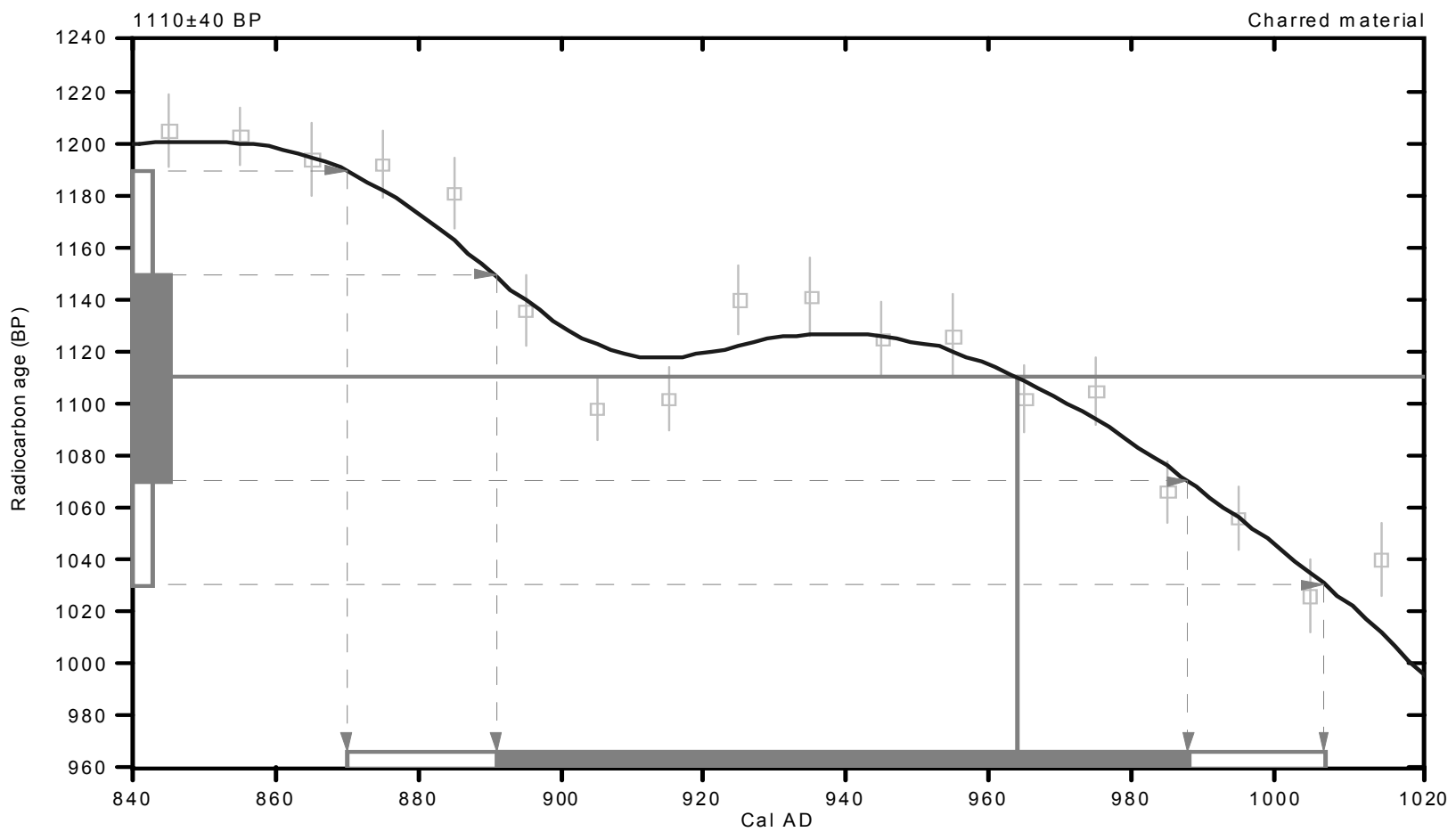

References:

Database used

Calibration Database

Editorial Com ment

Stuiver, M., van der Plicht, H., 1998, Radiocarbon 40(3), pxii-xiii

IN TCAL98 Radiocarbon Age Calibration

Stuiver, M., et. al., 1998, Radiocarbon 40(3), p1041-1083

$M$ ath em atics

A Simplified Approach to Calibrating C14 Dates

Talma, A. S., Vogel, J. C., 1993, Radiocarbon 3 5(2), p317-322

\section{Beta Analytic Inc.}

4985 SW 74 Court, Miami, Florida 33155 USA $\cdot$ Tel: (305)6675167・Fax:(305)6630964・E-Mail: beta@radiocarbon.com 


\section{CALIBRATION OF RADIOCARBON AGE TO CALENDAR YEARS}

(V ariables: C $13 /$ C $12=-24.3: 1 \mathrm{lab} . \mathrm{mult}=1$ )

\section{Laboratory number: Beta-163790}

Conventional radiocarbon age: $3060 \pm 40 \mathrm{BP}$

2 Sigm a calibrated result: Cal BC 1410 to 1210 (Cal B P 3360 to 3160 )

(95\% probability)

Intercept data

Intercepts of radiocarbon age

with calibration curve:

Cal B C 1360 (Cal B P 3310$)$ and

Cal B C 1360 (Cal B P 3300$)$ and

Cal B C 1320 (Cal B P 3260 )

1 Sigm a calibrated result:

Cal B C 1390 to 1280 (Cal B P 3340 to 3230 )

(68\% probability)

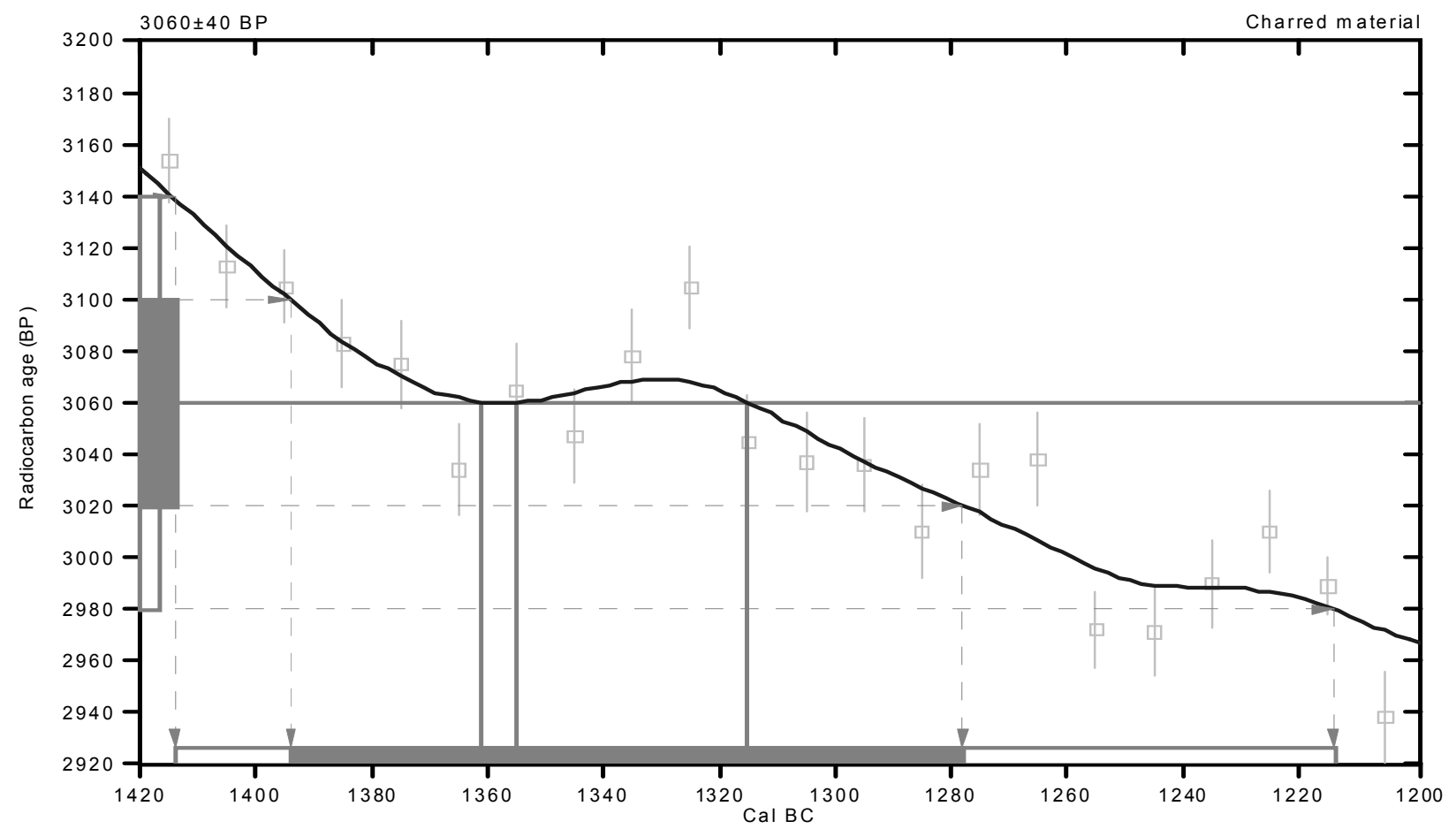

References:

Da tabase used

Calibration Database

Editorial Com ment

Stuiver, M., van der Plicht, H., 1998, Radiocarbon 40(3), pxii-xiii

IN TCAL 98 Radiocarbon Age Calibration

Stuiver, M., et. al., 1998, Radiocarbon 40(3), p1041-1083

$M$ ath em atics

A Simplified Approach to Calibrating C14 Dates

Talma, A.S., Vogel, J. C., 1993, Radiocarbon 3 5(2), p317-322

\section{Beta Analytic Inc.}

4985 SW 74 Court, Miami, Florida 33155 USA Tel: (305)6675167•Fax: (305)6630964・E-Mail: beta@ radiocarbon.com 



\section{Appendix D \\ Vertebrate Faunal Remains}

by

Barbara A. Meissner 


\section{Appendix D: $\quad$ Vertebrate Faunal Remains}

A total of 249 bones, weighing 203.85 grams, was recovered during the project (Tables D-1 and D-2). In general, the bone was highly fragmented. Much of the bone was mildly to moderately pitted by chemical weathering, probably as a result of biological activity (bacteria and fungi).

Only four bones could be identified to the genus taxonomic level:

a) Three white-tailed deer (Odocoileus virginianus); and

b) One blacktailed jackrabbit (Lepus californicus) (Table D-1).

The bones of a very large mammal - the size of a cow, horse, or bison - were observed, but could not be identified more precisely. Only one butchering mark was observed, an impact scar near the iliac crest of a bison-sized animal.

Table D-1. Faunal remains recovered from 41BX1421

\begin{tabular}{|l|l|r|r|}
\hline \multicolumn{1}{|c|}{ Taxa } & \multicolumn{1}{|c|}{ Common Name } & Count & Weight (g) \\
\hline \multicolumn{1}{|c|}{ Mammalia } & \multicolumn{1}{|c|}{ Mammals } & & \\
\hline Artiodactyl & Deer, sheep, goats & 3 & 4.53 \\
\hline Lepus californicus & Blacktailed jackrabbit & 1 & 0.56 \\
\hline Odocoileus virginianus & White-tailed deer & 3 & 11.00 \\
\hline Mammal--small & Rabbit-sized & 3 & 0.60 \\
\hline Mammal--large & Deer, sheep-sized & 11 & 63.49 \\
\hline Mammal--very large & Cattle, bison, horse-sized & 191 & 67.55 \\
\hline Mammal & Size indeterminate & 55.87 \\
\hline & \multicolumn{1}{|c|}{ Total Mammals } & $\mathbf{2 4 7}$ & $\mathbf{2 0 3 . 6 0}$ \\
\hline Aves & Birds & 2 & 0.25 \\
\hline Aves & Size indeterminate & $\mathbf{2}$ & $\mathbf{0 . 2 5}$ \\
\hline & Total Birds & $\mathbf{2 4 9}$ & $\mathbf{2 0 3 . 8 5}$ \\
\hline
\end{tabular}


Table D-2. Distribution of faunal remains by unit and level

\begin{tabular}{|c|c|c|c|c|c|c|c|c|c|c|c|c|c|}
\hline Cat \# & Unit & 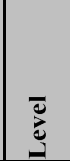 & Taxon & $\begin{array}{l}\vec{E} \\
\bar{z} \\
\dot{u}\end{array}$ & \begin{tabular}{|c} 
Wgt \\
(g)
\end{tabular} & Element & Portion & $\frac{5}{5}$ & 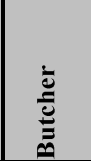 & 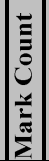 & & 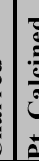 & \\
\hline $52-001$ & TU-1 & Wall & Mammal--large & 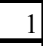 & 17.6 & & & & & & & & \\
\hline $05-003$ & TU-1 & 1 & Mammal & 2 & 0.9 & & & & & & & & . \\
\hline $06-014$ & TU-1 & 2 & Mammal--large & 2 & 2.99 & & & & & & & & \\
\hline $06-014$ & TU-1 & 2 & Mammal & 14 & 4.31 & & & & & & & 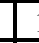 & 2 \\
\hline $07-004$ & TU-1 & 3 & Odocoileus virginianus & 2 & 6.98 & Metacarpal & Fragment of proximal end & $\mathrm{R}$ & & & & & \\
\hline $07-004$ & TU-1 & 3 & Mammal--large & 1 & 1.18 & & & & & & . & & \\
\hline $07-004$ & $\mathrm{TU}-1$ & 3 & Mammal & 8 & 3.18 & & & & & & & 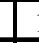 & 3 \\
\hline $08-008$ & TU-1 & 4 & Artiodactyl & 1 & 2.73 & Radial carpal & Complete & $\mathrm{R}$ & & & & & \\
\hline $08-008$ & TU-1 & 4 & Artiodactyl & 1 & 1.45 & Mandible & Fragment $\mathrm{w} /$ fragment of tooth & & & & & & \\
\hline $08-008$ & TU-1 & 4 & Artiodactyl & 1 & 0.35 & Molar & Fragment & & & & & & \\
\hline $08-008$ & TU-1 & 4 & Lepus californicus & 1 & 0.56 & Scapula & Glenoid fossa & $\mathrm{R}$ & & & 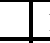 & - & \\
\hline $08-008$ & TU-1 & 4 & Mammal--small & 3 & 0.6 & & & & & & 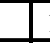 & & \\
\hline $08-008$ & TU-1 & 4 & Mammal--large & 7 & 9.7 & & & & & & 2 & - & \\
\hline $08-008$ & $\mathrm{TU}-1$ & 4 & Mammal & 45 & \begin{tabular}{|l|}
11.4 \\
\end{tabular} & & & & & & 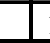 & 2 & 1 \\
\hline $08-008$ & TU-1 & 4 & Mammal & 9 & 2.88 & & & & & & 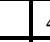 & & \\
\hline $08-008$ & TU-1 & 4 & Aves & 2 & 0.25 & & & & & & & & 2 \\
\hline $09-012$ & TU-1 & 5 & Odocoileus virginianus & 1 & 4.02 & Molar & Almost complete & & & & & & \\
\hline 09-012 & TU-1 & 5 & Mammal--large & 10 & 16.2 & & & & & & & & 2 \\
\hline $09-012$ & $\mathrm{TU}-1$ & 5 & Mammal & 26 & 5.67 & & & & & & & & 2 \\
\hline $12-007$ & TU-1 & 7 & Mammal--very large & 2 & 7.44 & & & & & & & & \\
\hline $12-007$ & TU-1 & 7 & Mammal & 1 & 0.21 & & & & & & & & \\
\hline $22-003$ & TU-3 & 1 & Mammal--large & 1 & 0.62 & & & & & & & & 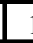 \\
\hline $27-005$ & TU-3 & 4 & Mammal--large & 4 & 6.47 & & & & & & & & \\
\hline $27-005$ & $\mathrm{TU}-3$ & 4 & Mammal & 9 & 3.28 & & & & & & & & $\varepsilon$ \\
\hline $28-004$ & TU-3 & 5 & Mammal--large & 3 & 3.51 & & & & & & & & \\
\hline $28-004$ & TU-3 & 5 & Mammal & 12 & 1.8 & & & & & & & & \\
\hline $37-006$ & $\mathrm{TU}-5$ & 2 & Mammal--large & 4 & \begin{tabular}{|l|}
3.8 \\
\end{tabular} & & & & & & & & \\
\hline $37-006$ & $\mathrm{TU}-5$ & 2 & Mammal--very large & 1 & \begin{tabular}{|l|l|}
17.6 \\
\end{tabular} & Innominate & Fragment of ischium & & Impact & 1 & & & \\
\hline $37-006$ & TU-5 & 2 & Mammal--very large & 2 & 26.8 & & & & & & & & \\
\hline $37-006$ & TU-5 & 2 & Mammal--very large & 1 & \begin{tabular}{|l|l|}
0.88 \\
\end{tabular} & & & & & & & & \\
\hline $37-006$ & TU-5 & 2 & Mammal & 24 & 11.2 & & & & & & & & \\
\hline $37-006$ & TU-5 & 2 & Mammal & 14 & 3.45 & & & & & & & 2 & 2 \\
\hline $37-006$ & TU-5 & 2 & Mammal & 1 & 0.25 & & & & & & & 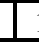 & \\
\hline $38-006$ & TU-5 & 3 & Mammal--very large & 1 & \begin{tabular}{|l|l|}
4.46 \\
\end{tabular} & & & & & & & & \\
\hline $38-006$ & TU-5 & 3 & Mammal & 7 & \begin{tabular}{|l|}
2.67 \\
\end{tabular} & & & & & & & 2 & - \\
\hline $39-005$ & $\mathrm{TU}-5$ & 4 & Mammal--very large & 1 & \begin{tabular}{|l|}
5.52 \\
\end{tabular} & & & & & & & & \\
\hline $39-005$ & TU-5 & 4 & Mammal & 12 & 2.61 & & & & & & 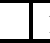 & 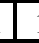 & 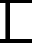 \\
\hline $42-008$ & TU-5 & 5 & Mammal--large & 4 & 0.75 & & & & & & & & \\
\hline $42-008$ & TU-5 & 5 & Mammal & 3 & \begin{tabular}{|l|l|}
1.36 \\
\end{tabular} & & & & & & - & 2 & 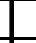 \\
\hline 43-004 & TU-5 & 6 & Mammal--large & 1 & \begin{tabular}{|l|}
0.66 \\
\end{tabular} & & & & & & 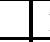 & & \\
\hline 44-005 & TU-5 & & Mammal & 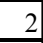 & 0.29 & & & & & & 2 & & \\
\hline $45-001$ & TU-5 & 8 & Mammal--very large & 1 & 2.43 & & & & & & 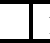 & & \\
\hline $45-001$ & TU-5 & & Mammal & 2 & 0.38 & & & & & & & 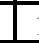 & \\
\hline 46-006 & $\mathrm{TU}-5$ & & Mammal--very large & 2 & 2.41 & & & & & & & & \\
\hline
\end{tabular}


The following information is provided in accordance with the General Rules of Practice and Procedure, Chapter 26.24 (Investigative Reports), Texas Antiquities Committee:

1. Type of investigation: Testing

2. Project name: Medio Creek (41BX1421) Testing

3. County: Bexar

4. Principal investigators: Raymond P. Mauldin

5. Name and location of sponsoring agency: Texas Department of Transportation, 125 East 11th Street, Austin, TX 78701-2483

6. Texas Antiquities Permit No.: 2569

7. Published by the Center for Archaeological Research, The University of Texas at San Antonio, 6900 N. Loop 1604 W., San Antonio, Texas 78249-0658, 2002

A list of publications offered by the Center for Archaeological Research is available. Call (210) 458-4378; write to the Center for Archaeological Research, The University of Texas at San Antonio, 6900 N. Loop 1604 W., San Antonio, Texas 78249-0658; e-mail to car@lonestar.utsa.edu; or visit CAR's web site at http://car.utsa.edu. 